\title{
ARTICLE
}

\section{ALL ABOUT WORDS: EARLY UNDERSTANDINGS OF THE "JUDICIAL POWER" IN STATUTORY INTERPRETATION, 1776-1806}

\author{
William N. Eskridge, Jr**
}

\begin{abstract}
What understanding of the "judicial Power" would the Founders and their immediate successors possess in regard to statutory interpretation? In this Article, Professor Eskridge explores the background understanding of the judiciary's role in the interpretation of legislative texts, and answers earlier work by scholars like Professor John Manning who have suggested that the separation of powers adopted in the U.S. Constitution mandate an interpretive methodology similar to today's textualism. Reviewing sources such as English precedents, early state court practices, ratifying debates, and the Marshall Court's practices, Eskridge demonstrates that while early statutory interpretation began with the words of the text, it by no means confined its search for meaning to the plain text. He concludes that the early practices, especially the methodology of John Marshall, provide a powerful model, not of an anticipatory textualism, but rather of a sophisticated methodology that knit together text, context, purpose, and democratic and constitutional norms in the service of carrying out the judiciary's constitutional role.
\end{abstract}

\section{TABLE of Contents}

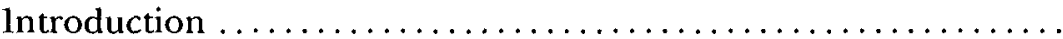

1. Three Nontextualist Powers Assumed by English Judges,

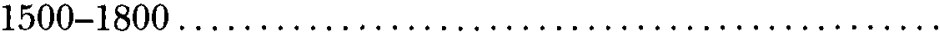

A. The Ameliorative Power..................... 999

B. Suppletive Power (and More on the Ameliorative Power)

C. Voidance Power

II. Statutory Interpretation During the Founding Period, $1776-1791$

* John A. Garver Professor of Jurisprudence, Yale Law School. I am indebted to John Manning for sharing his thoughts about the founding and consolidating periods; although we interpret the materials differently, I have learned a lot from his research and arguments. I am grateful to Jim Chen, Stephen Choi, Dan Farber, John Langbein, Dan Kahan, Brett McDonnell, David McGowan, Miranda Oshige McGowan, Randy Schoette, John Yoo, and Kenji Yoshino (as well as various questioners at University of Minnesota and Yale Law School workshops) for helpful comments on an earlier draft of this Article. Martin Flaherty deserves special thanks, both for his comments on two earlier drafts of this Article, and for the elevated level of professionalism he has brought to legal history and its treatment of the founding period. Shemina Kanji, Yale Law School Class of 2002; Travis LeBlanc, Yale Law School Class of 2002; and Michael Shumsky, Yale Law School Class of 2003, provided excellent and needed research assistance. 
A. Suppletive Power ....................... 1018

B. Ameliorative Powers.......................... 1021

C. Voidance Power ....................... 1025

III. Judicial Power and Statutory Interpretation at the Philadelphia Convention, $1787 \ldots \ldots \ldots \ldots \ldots \ldots \ldots . .1030$

IV. Statutory Interpretation and the Ratifying Debates, 1787-89 .................................... 1040

V. Early Statutory Interpretation by Federal Judges, 1791-1806 ................................... 1058

A. The Jay and Ellsworth Courts, $1789-1801 \ldots \ldots \ldots \ldots 1060$

B. The Early Marshall Court, $1801-07 \ldots \ldots \ldots \ldots \ldots .1070$

C. Provisional Conclusions About Early Federal Statutory

Decisions ................................... 1082

VI. The Relevance of the Founding History to Statutory Interpretation Today? ...................... 1087

A. Original Intent about the Judicial Power in Statutory Interpretation? The Three Faces of Textualism ..... 1088

B. The Relationship Between Text and Context ....... 1096

C. Insights About the Canons of Statutory Construction and Recent Decisions .......................... 1099

\section{INTRODUCTION}

Academic debates about statutory interpretation methodology have increasingly involved competing "faithful agent" versus "cooperative partner" understandings of the role of federal judges. The legal process understanding of judges who are partners in the ongoing process of lawmaking has been challenged by scholars who maintain that the Constitution's separation of powers requires judges to be nothing more than faithful agents of the legislature in statutory interpretation cases. ${ }^{1}$ While both schools of thought criticize methodologies that insist judges must implement the original legislative intent behind statutes, ${ }^{2}$ they diverge in cases where the facts of the case, the evolving statutory scheme,

1. Compare Henry M. Hart, Jr. \& Albert M. Sacks, The Legal Process 1-4, 1374-80 (William N. Eskridge, Jr. \& Philip P. Frickey eds., 1994) (1958) (arguing that law is purposive, and the role of courts is to carry forward the goals of particular laws and of the legal system as it evolves over time), with Frank H. Easterbrook, Text, History, and Structure in Statutory Interpretation, 17 Harv. J.L. \& Pub. Pol'y 61, 63 (1994) (contrasting "faithful agents" with "independent principals").

2. Compare William N. Eskridge, Jr., Dynamic Statutory Interpretation 10-11 (1994) [hereinafter Eskridge, Dynamic lnterpretation] (showing that the courts actually follow nonoriginalist approaches to construing statutes and that often this practice is legitimate), with Antonin Scalia, Common-Law Courts in a Civil Law System: The Role of United States Federal Courts in Interpreting the Constitution and Laws, in A Matter of Interpretation 3, 16-18, 29-37 (Amy Gutmann ed., 1997) (arguing that attempting to discern legislative intent is an illegitimate goal in statutory interpretation and that "legislative history" is best ignored). 
and the legal landscape press statutory texts beyond what faithful agent theorists consider to be their "plain meanings." In my view, Article III judges interpreting statutes are both agents carrying out directives laid down by the legislature and partners in the enterprise of law elaboration, for they (like the legislature) are ultimately agents of "We the People." I also dissent from the narrow view of statutes and the stingy understanding of plain meaning often followed by leading faithful agent jurists, like Justice Scalia, who are also avatars of what I call the new textualism. ${ }^{4}$

My partnership-cum-agency model and a context-sensitive reading of statutory texts best reflect the Supreme Court's practice in statutory cases during the twentieth century. ${ }^{5}$ The new textualist judges seemingly concede this fact, for they fiercely criticize the Court's tendency to read statutes beyond or against what they believe to be their plain meanings. ${ }^{6}$ Given the long-established practice of the Court, I have challenged the new textualists to provide a robust defense of their methodology, which would, if adopted, require a substantial change in the way the Supreme Court goes about interpreting statutes. One of my challenges has been for the new textualists to justify their methodology by reference to the original understanding of Article III's "judicial Power," which strikes me as friendlier to a pragmatic rather than strictly textualist methodology. ${ }^{7}$ Professor John Manning is the new textualism's main defender-and an impressive one. His important article in this Review usefully situates his-

3. U.S. Const. pmbl.; see William N. Eskridge, Jr., Spinning Legislative Supremacy, 78 Geo. L.J. 319, 322-30 (1989). Moreover, in the modern state, the primary agents of the legislature are administrative bodies. See Edward L. Rubin, Law and Legislation in the Administrative State, 89 Colum. L. Rev. 369, 372-74 (1989).

4. William N. Eskridge, Jr., The New Textualism, 37 UCLA L. Rev. 621, 624 (1990) [hereinafter Eskridge, New Textualism]. The theoretical debate is beclouded by the general alignment of the players: Those associated with conservative causes, like Justice Scalia and Judge Easterbrook, are leading theorists of the new textualism, while political moderates, like Justice Stevens and Judge Posner, are leading context-based, pragmatic theorists. The former group tends to read the same statutory texts more stingily than the latter group. Interestingly, although judges with different methodological commitments diverge in their interpretations, academics with different approaches, like John Manning (new textualist) and myself (agent-and-partnership), often read texts very similarly. See infra Part VI.

5. E.g., William N. Eskridge, Jr. \& Philip P. Frickey, Statutory Interpretation as Practical Reasoning, 42 Stan. L. Rev. 321, 360 (1990) [hereinafter Eskridge \& Frickey, Practical Reasoning]; Jane S. Schacter, The Confounding Common Law Originalism in Recent Supreme Court Statutory Interpretation: Implications for the Legislative History Debate and Beyond, 51 Stan. L. Rev. 1, 1 (1998); Peter L. Strauss, On Resegregating the Worlds of Statute and Common Law, 1994 Sup. Ct. Rev. 429, 436-47; Nicholas S. Zeppos, The Use of Authority in Statutory Interpretation: An Empirical Analysis, 70 Tex. L. Rev. 1073, 1076 (1992).

6. See, e.g., Scalia, supra note 2, at 18-23.

7. William N. Eskridge, Jr., Textualism, the Unknown Ideal?, 96 Mich. L. Rev. 1509, 1522-32 (1998) [hereinafter Eskridge, Unknown 1deal]. 
toricist questions about the constitutional pedigree of the new textualism and then creatively goes about answering those questions. ${ }^{8}$

Specifically, Manning tries to tie the modern partnership or pragmatic theory to the old English tradition of equitable interpretation, which he maintains was substantially repudiated in favor of the modern faithful agent theory by the separation of powers principles entailed in the Constitution. Manning's historical storyline is that English judges freely rewrote statutes in the medieval and early modern periods because England did not enjoy a system of separated powers; ${ }^{9}$ those judges retreated from this practice once parliamentary supremacy and some separation became established; ${ }^{10}$ and American judges after 1801 completed the transition to a faithful agent approach because of the more complete separation of judicial from legislative powers in the American Constitution. ${ }^{11}$ Independent of this historical exegesis, Manning presents a kinder, gentler version of the new textualism-distancing that method from rigid literalism. ${ }^{12}$

Manning's defense of the faithful agent theory and the new textualism strikes me as learned and brilliantly analytical but-like my own earlier challenge-not sufficiently historicist. ${ }^{13}$ After an immersion in the original sources and historical scholarship for the founding period, 1 remain unpersuaded that the founding generation radically rethought statutory interpretation because of their decision to separate the legislative, executive, and judicial powers of the national government. Although Manning invokes the leading historians of the founding period (Gordon Wood and Jack Rakove), he has not internalized the consensus insights of the secondary literature, which are unfriendly to his particular themes. Wood's thesis remains the standard account: There was much distrust of the judiciary and of judicial equity during the revolutionary period (1770s and early $1780 \mathrm{~s}$ ); that distrust was overtaken by a greater distrust of legislative bodies, thereby creating a climate of opinion receptive to judicial review and equitable construction of statutes to protect liberty $(1780 \mathrm{~s})$; and the Framers at Philadelphia and the state ratifying conventions (I787-9I) were operating under these latter assumptions, for the

8. John F. Manning, Textualism and the Equity of the Statute, 101 Colum. L. Rev. 1 (2001) [hereinafter Manning, Equity of the Statute].

9. Id. at $37-46$.

10. Id. at $47-55$.

11. Id. at 56-101.

12. See id. at 105-26.

13. While not "law office history" trumped up to support a preexisting political stance, cf. Mark Tushnet, Interdisciplinary Legal Scholarship: The Case of History-in-Law, 71 Chi.Kent L. Rev. 909, 917-18 (1996) (describing and critiquing one-sided historical accounts), neither Manning nor I fully met the challenges posed by Professor Martin Flaherty in History "Lite" in Modern American Constitutionalism, 95 Colum. L. Rev. 523, 525-28 (1995) [hereinafter Flaherty, History Lite]. 
most part. ${ }^{14}$ Wood's thesis is inconsistent with Manning's reading of American attitudes toward judges, his insistence on the Framers' acceptance of a strict formal separation of powers, and his presentation of the new professionalism among judges as entailing textualist theory and practice rather than a theory emphasizing coherence with various sources of fundamental law. ${ }^{15}$ To the extent that Manning's account challenges the consensus of professional historians, he bears the burden of proof to demonstrate that his analysis is the superior one.

Manning is a challenger who cannot meet his burden. Professional historians have been critical of neoformalist efforts to justify the theory of strict and formal separation of powers by reference to the founding period. ${ }^{16}$ At the time of the constitutional framing, "separation of powers" did not mean what it means to neoformalist scholars and judges today. The Framers were functionalist in their orientation, emphasizing checks and balances more than stringent separation of functions. Nowhere was

14. Gordon S. Wood, The Creation of the American Republic: 1776-1787, at 291-305 ("The Ambiguity of American Law"), 403-13 ("The Abuses of Legislative Power"), 453-63 ("The Enhancement of the Judiciary") (1969) [hereinafter Wood, Creation]; see Flaherty, History Lite, supra note 13, at 536-45, for a useful analysis of the Wood thesis and supporting historiography; see also Jack N. Rakove, Original Meanings: Politics and Ideas in the Making of the Constitution 19 (1996) [hereinafter Rakove, Original Meanings] (arguing that the early separation of powers doctrine offered "no simple formulas to determine the exact form the new government should take"); Forum, $44 \mathrm{Wm}$. \& Mary Q., 3d Ser. 549-640 (1987) (symposium elaborating on and largely reaffirning the Wood thesis).

15. Likewise, I do not read the primary and secondary sources as supporting Manning's implicit assumption that the modern debate between "faithful agent" and "partnership" theorists tracks the eighteenth-century debate between those following the letter of the law and others willing to narrow or expand the letter for equitable reasons. Even less do the original materials support a supposition that faithful agents strictly enforce statutory texts precisely as written. Instead, judges and lawyers in the founding and consolidating periods believed that fidelity to statutory texts involved careful contextual and even normative analysis. See infra Parts II-V.

16. See Martin S. Flaherty, The Most Dangerous Branch, 105 Yale L.J. 1725, 1755-76 (1996) [hereinafter Flaherty, Most Dangerous Branch] (arguing that the Founders did not understand "separation of powers" in anything like formalist terms and, instead, emphasized checks and balances to assure that government could not act without the cooperation of all three interacting branches); see also Forrest McDonald, The Presidency of George Washington 172-74 (1974) (detailing how controversy over Jay treaty prompted struggle between Executive, Senate, and House of Representatives over prerogative); Gerhard Casper, An Essay in Separation of Powers: Some Early Versions and Practices, 30 Wm. \& Mary L. Rev. 211, 211-12 (1989) (emphasizing the complexity and functional focus of the Framers' approach to the federal government's structure); Maeva Marcus, Separation of Powers in the Early National Period, $30 \mathrm{Wm}$. \& Mary L. Rev. 269, 269-70 (1989) (concluding that the decisions of the earliest Supreme Court Justices were not "rooted in preconceived ideas about the role of the judiciary vis-à-vis the executive and legislative branches" but were instead "reactions to circumstances that arose" during early years of the nation's existence). The leading historical defense of formalist thinking about separation of powers is Steven G. Calabresi \& Saikrishna B. Prakash, The President's Power To Execute the Laws, 104 Yale L.J. 541 (1994), to which Flaherty, Most Dangerous Branch, supra, is a detailed historical response. 
this more apparent than in the Founders' attitudes toward the legislature. To prevent injustices by the most dangerous branch, the least dangerous one-no less an agent of "We the People"-was expected to strike down unconstitutional laws, trim back unjust and partial statutes, and make legislation more coherent with fundamental law. Manning's account suffers from the historiographical problems associated with previous historicist theories of strict formal separation of powers, plus a number of other quandaries. One example, the triumph of textualism, even by his account, came not at the Philadelphia Convention, nor during the ratification debates, nor during the Jay and Ellsworth Courts (1789-1801), but with the ascendance of John Marshall as Chief Justice, half a generation after the Constitution was drafted and adopted. ${ }^{17}$ Yet Marshall's first great opinion, Marbury $v$. Madison, ${ }^{18}$ utterly rewrote the statute the Court was interpreting, and his other early opinions played with statutory text the way a cat plays with a mouse before devouring it. ${ }^{19}$ So there is paradox as well as anachronism in Manning's history.

Unfortunately, I did no better in my earlier challenge, which read current debates and terminologies back into the founding era, superficially invoked isolated quips from the ratification debates, and failed to grapple with the complex historiographical literature as well as a broad range of primary sources. ${ }^{20}$ My main goal in this Article is to do a more thorough job of examining the founding generation's experience with and discourse about statutory interpretation from its perspective and with greater historiographical sophistication.

Like prior authors, ${ }^{21}$ I start with the English background for the American practice of statutory interpretation in Part I. English judges and commentators did not articulate a faithful agent theory or the plain meaning rule, and they had only a rudimentary and evolving theory of separation of powers. Judges did emphasize the words of the statute and the letter of the law but did not consider these elements the end of statutory analysis. The "equity of the statute" idea discussed by Manning captures some, but not most, of the flexibility judges believed they enjoyed in applying the letter of the law to the facts of unanticipated cases. In its strict literal sense, the term "equity of the statute" only referred to judicial

17. See infra Part V.B.

18. 5 U.S. (1 Cranch) 137 (1803), analyzed at infra notes 408-414 and accompanying text.

19. See infra notes $416-426$ and accompanying text.

20. See Eskridge, Unknown ldeal, supra note 7, at 1523-31; see also William $\mathbf{N}$. Eskridge, Jr., Dynamic Statutory Interpretation, 135 U. Pa. L. Rev. 1479, 1500-03 (1987) (discussing founding generation's views on statutory interpretation).

21. See William D. Popkin, Materials on Legislation: Political Language and the Political Process 11-33 (3d ed. 2001) [hereinafter Popkin, Legislation]; William D. Popkin, Statutes in Court: The History and Theory of Statutory Interpretation 9-29 (1999) [hereinafter Popkin, Statutes in Court]; see also Manning, Equity of the Statute, supra note 8, at 27-56 (describing English antecedents to the "judicial Power"). 
extension of statutory terms to a casus omissus, the unprovided-for case. ${ }^{22}$ But judges also narrowed statutory terms, sometimes on grounds of equity, and sometimes as a matter of precedent or judgment. Under nonliteralist constructions, judges expanding or narrowing the words of statutes did not see themselves as engaging in judicial legislation or lawmaking, a matter increasingly disfavored in the English materials, but instead saw themselves exercising their judicial power to discover or apply the law. Analytically, it is productive to identify three different situations when eighteenth-century English judges believed themselves required or authorized to depart from or compromise the words or letter of a statute. Judges asserted what 1 call ameliorative, suppletive, and voidance powers when they concededly interpreted statutes contrary to the apparent meaning of the words used by Parliament; only the middle power was justified by the equity of the statute concept. In England, the voidance power was most controversial and the ameliorative power most robust by 1776.

The next three parts of this Article examine the assumptions about the judicial power by American judges and constitutionalists during our founding period, 1776-1791. I start with state court practice in Part II, then examine the discussions at Philadelphia in Part III, and in the rest of the country during the ratification process in Part IV. Although it remained controversial, the voidance power enjoyed both a revival and a transformation in this country. It was rearticulated as a judicial review power, with strong consequences for statutory interpretation: When the letter of the law seemed to be at variance with a higher authority, typically the Constitution, courts were obliged to narrow the statute's words. The ameliorative power stirred little concern or critical comment. There was wide agreement, even by opponents of the Constitution, that this power was necessary to preserve liberty against inadvertent or even intentional overreaching by Congress, the most feared branch. The suppletive (equity of the statute) power was controversial insofar as writers critical of the

22. The English doctrine of lequity de lestatut was derived from the Roman law concept that gaps in statutes could be filled by analogy to other parts of the statute or of the code. See 1 John Norton Pomeroy, A Treatise on Equity Jurisprudence As Administered in the United States of America 36 (Spencer W. Symons ed., Bancroft-Whitney Co. 1941) (1881); Samuel Thorne, The Equity of a Statute and Heydon's Case, 31 Ill. L. Rev. 202, 206-10 (1936). The early cases and commentaries sometimes used the terms equity and equitable more broadly, to include narrowing a broad statute as well as filling in gaps in narrow statutes, e.g., 1 Pomeroy, supra, at 36-37, but the equity of the statute was generally limited to the latter. Manning's broader use of the term is hardly unprecedented, e.g., James $M$. Landis, Statutes and the Sources of Law, in Harvard Legal Essays 213, 214-18 (1934); Hans W. Baade, The Casus Omissus: A Pre-History of Statutory Analogy, 20 Syracuse J. Int'l L. \& Com. 45, 80-81 (1994), but I prefer to use the term only in its original sense. See also Allen Dillard Boyer, "Understanding," "Authority," and "Will": Sir Edward Coke and the Origins of Judicial Review, 39 B.C. L. Rev. 43, 76-77 (1997) (explaining early understandings of the term "equity of the statute"); W.H. Loyd, The Equity of a Statute, 58 U. Pa. L. Rev. 76, 83 (1909) (explaining original, seventeenth-century understanding of term). 
Constitution feared it would expand national or state authority at the expense of state or individual liberty.

Part V examines early statutory practice by federal judges-circuit court as well as Supreme Court cases in the period of consolidation. The voidance power, recast as a power of judicial review, inspired federal judges to rewrite or narrow congressional enactments in an increasing array of cases. Federal judges also vigorously but, after an initial false step in Chisholm v. Georgia, ${ }^{23}$ prudently ameliorated and supplemented statutory language in a wide range of cases. What we today would call statutory text was given center stage, particularly during the Marshall Court. Although the plain meaning rule was not yet clearly articulated as necessary to the rule of law or separation of powers in any opinion that I read, John Marshall moved the debate away from the equity/letter distinction and toward sophisticated analysis of statutory provisions as part of a coherent body of law consisting of judicial decisions and the common law, other statutes, and the Constitution and its own common law. If Marshall was a textualist, as Manning maintains, he was at best a strategic one, as his performance in Marbury illustrates. His opinions run the gamut of methodologies but do consistently take a complex approach to text, as imbued with history, principles, and political choices. One of the things Marshall accomplished was to situate the Supreme Court as a specialized tribunal whose views about the law were justified by the professional, technical analysis that judges like him could bring to bear on legal texts. The professionalism of the Marshall Court, however, was not just a textual proficiency, but a learned integration of statutes into the broader fundamental principles of the common law, equity and fairness, the law of nations, and the Constitution itself.

After this excavation of the historical context within which the Constitution's Framers and ratifiers understood the judicial power as it regards statutory interpretation, I shall offer in Part VI some thoughts about what normative bite this history should have for current doctrinal and theoretical debates about statutory interpretation. My main conclusion is that the original materials surrounding Article III's judicial power assume an eclectic approach to statutory interpretation, open to understanding the letter of a statute in pursuance of the spirit of the law and in light of fundamental values. Furthermore, the original materials suggest that the founding generation expected judges certainly to trim the letter of the law to protect common law liberties and probably sometimes to expand the letter of the law to unprovided-for cases. Finally, I note several limitations to the conclusions that can be drawn from the materials. For example, the materials shed little light on the debate about the utility of legislative history, in part because judges in the founding era often knew that history and usually had no published reports which could be cited. Similarly, the early federal cases and most of the state cases rarely 
presented the toughest issues of statutory interpretation-cases where judges must apply (older) statutes to dramatically different circumstances from those assumed by the authors of statutes. In those difficult cases, dynamism is inevitable in statutory interpretation and simple textualism least defensible.

The more I immersed myself in the sources and in Manning's article, a project that began as a test of the new textualism's historiographical claims evolved into a project exploring deeper lessons about how judges grapple with texts. The central lesson of the early period, best embodied in the work of John Marshall, is that statutory interpretation is all about words, but words are about much more than dictionaries and ordinary usage; they also involve policies chosen by the legislature and enduring principles suggested by the common law, the law of nations, and the Constitution. Just as the United States created a new kind of constitutionalism, popular and written, so its new constitutionalism inspired a new kind of statutory interpretivism, text-based but principled, sometimes equitable, and frequently dynamic. A lesson I draw from the founding period is that what we today call a statutory "plain meaning" does not preexist the judge's exploration of the statutory language in the context of the broader landscape of the law, the facts of the case, and (for the Supreme Court especially) the strategic context within which the interpretation occurs. This is the most subtle disagreement I have with Professor Manning. "When the words of a statute are unambiguous," say the new textualists, "'judicial inquiry is complete." 24 To the extent this assumes that the "unambiguity" of the statutory words is not in part a product of a contextualized "judicial inquiry," I believe this viewpoint is misleading. Indeed, the greatest insight of Manning's historicist article is its presentist argument for a sensible textualism which sees more ambiguity and play in statutes than Manning's judicial mentors usually accept in their decisions.

\section{Three Nontextualist Powers Assumed by English JuDGES, 1500-1800}

In figuring out what understandings the Founders in the $1780 \mathrm{~s}$ would have had concerning statutory interpretation, it is useful to start with pre-1776 English practice. ${ }^{25}$ Such practice may help us see assump-

24. Connecticut Nat'l Bank v. Germain, 503 U.S. 249, 254 (1992) (Thomas, J.) (quoting Rubin v. United States, 449 U.S. 424, 430 (1981)), quoted in Manning, Equity of the Statute, supra note 8 , at 17 .

25. This follows the methodology laid out by Flaherty, History Lite, supra note 13. For examples of historical expositions that shed light on original expectations along these lines, see David M. Golove, Treaty-Making and the Nation: The Historical Foundations of the Nationalist Conception of the Treaty Power, 98 Mich. L. Rev. 1075, 1100-1209 (2000); Laura Kalman, Border Patrol: Reflections on the Turn to History in Legal Scholarship, 66 Fordham L. Rev. 87, 89 (1997); William Michael Treanor, Fame, the Founding, and the Power to Declare War, 82 Cornell L. Rev. 695, 699-701 (1997); John C. Yoo, The Continuation of Politics by Other Means: The Original Understanding of War Powers, 84 Cal. L. Rev. 167, 167-68 (1996). Compare John C. Yoo, Globalism and the Constitution: 
tions the early Americans would have made or, at least, the issues they would have considered important. In fact, the early modern period yielded rich discussions of statutory interpretation by English judges and commentators. ${ }^{26}$

English judges freely went beyond the letter or words of statutes throughout the early modern period, but this freedom became increasingly controversial. By the 1770s, English judges and commentators placed more emphasis on statutory words than they had in the I500s, but still claimed and frequently exercised a power to extend or, especially, narrow the letter of the law. Although some of the judicial decisions invoked the Roman law idea of "equity of the statute" to justify judicial extension of statutory words to cover omitted cases, ${ }^{27}$ the large majority of the decisions did not rely on that idea. Instead, most invoked the common law, general equity, and statutory spirits to narrow rather than expand statutory words. Thus, at the outset, the historical materials do not support Manning's focus on the equity of the statute as the basis for nonliteral interpretations.

A better way to organize the English cases is suggested by leading thinkers of the period-Plowden and Coke. Most of the cases involve what I call judges' ameliorative power to read statutory words narrowly rather than broadly. This power is as old as Aristotle and is a matter of simple interpretation. Some of the cases involve what I call judges' suppletive power to read statutory words broadly to include apparently unprovided-for cases. The equity of the statute tag usually shows up in these cases, which are on the whole more unusual. A third voidance power to nullify statutes was the most controversial of all, because England did not have a written constitution. But the power was exercised in an ameliorative way that muted criticism.

\section{A. The Ameliorative Power}

The King's Bench in 1574 decided the case of Eyston $v$. Studd. ${ }^{28}$ Thomas Eyston sued Richard Studd for trespass. The plaintiff claimed

Treaties, Non-Self-Execution, and the Original Understanding, 99 Colum. L. Rev. 1955, 1956 (1999), with Martin S. Flaherty, History Right? Historical Scholarship, Original Understanding, and the Treaties as "Supreme Law of the Land," 99 Colum. L. Rev. 2095, 2099 (1999) ) [hereinafter Flaherty, History Right].

26. Popkin, Statutes in Court, supra note 21, at 9-29, and Manning, Equity of the Statute, supra note 8 , at 43-56, argue that theory and practice changed as statutes became more numerous and complex, judges grew less involved in the enactment process, and Parliament increasingly asserted itself as the source of sovereignty and statutory legitimacy. This is the account developed by the leading historians. Baade, supra note 22, at 68-73; J.A. Corry, Administrative Law and the Interpretation of Statutes, 1 U. Toronto L.J. 286, 294-98 (1936); Thorne, supra note 22, at 202-04. Because I did not read the English cases in the comprehensive way I have read the American ones, I do not revisit this prior scholarship.

27. See supra note 22 .

28. 2 Plowden 459, 75 Eng. Rep. 688 (K.B. 1574). 
the land through a lease from John Latton, the son of Margaret and the late William Latton. The defendant claimed the land through a demise from Margaret and her second husband. Eyston replied that Studd's lease was invalid pursuant to a fifteenth-century law which prevented widows from alienating property they had held "in tail jointly" as a result of "the purchase or inheritance" of or with their husbands. ${ }^{29}$ The court accepted that the law applied to the land in suit and described the statute as being one made "to preserve the right to their heirs of the husband"therefore to be liberally construed for the benefit of the heir (Latton and, through him, Eyston). Nonetheless, the court ruled for the lessor of the widow (Studd):

[T] hey took it that the intent of statutes is more to be regarded and pursued than the precise letter of them, for oftentimes things, which are within the words of statutes, are out of the purview of them, . . . and the best way to construe an Act of Parliament is according to the intent rather than according to the words. ${ }^{30}$

The court found dispositive that the property in suit had originally been Margaret's inheritance, not her first husband's; it only fell within the words of the statute because she had arranged for the property to be jointly purchased by her and her first husband. Because plaintiff's claim did not rest on the protection of an heir's rightful claims to his father's estate and because defendant's claim rested on the decision of the wife to dispose otherwise of property that she had originally inherited, the court found the property outside the forfeiture of the statute and held for Studd, the defendant.

Eyston v. Studd is less notable for its holding and reasoning than for the commentary which the reporter, Plowden, attached to the reported decision. ${ }^{31}$ Although himself synthesizing past practice, Plowden's commentary became the most radical statement of equitable interpretation in the English-speaking legal world. The reporter memorably said that "it is not the words of the law, but the internal sense of it that makes the law, and our law (like all others) consists of two parts, viz. of body and soul, the letter of the law is the body of the law, and the sense and reason of the law is the soul of the law." ${ }^{32}$ And, he continued:

the law may be resembled to a nut, which has a shell and a kernel within, the letter of the law represents the shell, and the sense of it the kernel, and as you will be no better for the nut if you make use only of the shell, so you will receive no benefit by the law, if you rely only up on the letter, and as the fruit and profit of the nut lies in the kernel, and not in the shell, so the

29. 11 Hen. 7, c. 20 (Eng.).

30. Eyston, 2 Plowden at 464, 75 Eng. Rep. at 694 (footnote omitted).

31. See 2 Plowden at 465-68, 75 Eng. Rep. at 695-700.

32. 2 Plowden at 465, 75 Eng. Rep. at 695. 
fruit and profit of the law consists in the sense more than in the letter. ${ }^{33}$

Plowden rooted his nut theory in the idea of equity, which "enlarges or diminishes the letter [of the law] according to its discretion." 34 As the definition suggests, equitable interpretation can cut in one of two ways. On the one hand, equity "puts an exception to the generality of the text of the statute law"-or, as Aristotle had said, "equity is the correction of the general words when the matter falls outside their sense." ${ }^{35}$ Plowden provided numerous examples from prior cases of what I call the ameliorative power of judges. For example, when Parliament directs that whosoever does a specified act is a felon and shall be put to death, the general words of the statute should not be interpreted to apply to persons outside the statutory purview-such as a man of unsound mind or an infant of tender age. ${ }^{36}$ Again invoking Aristotle, Plowden argued, "experience shews us that no law-makers can foresee all things which may happen, and therefore it is fit that if there is any defect in the law, it should be reformed by equity, which is no part of the law, but a moral virtue which corrects the law." 37

Plowden was hardly alone in his endorsement of Aristotle's notion that generally phrased statutes are subject to equitable exceptions. All the early modern treatises on statutory interpretation approvingly recognized a similar exception. Citing Plowden and Eyston, the collection of canons of statutory construction in Mathew Bacon's widely known Abridgment of the Law included this one: "In some Cases the Letter of an Act of Parliament is restrained by an equitable Construction; in others it is enlarged; in others the Construction is contrary to the Letter." 38 Even the most conservative treatise of the era endorsed this ameliorative rule. For

33. Id.

34. Id.

35. 2 Plowden at 465, 75 Eng. Rep. at 696. I have translated Plowden's Latin version of Aristotle: "Equitas est correctio legis generatim latae quâ parte deficit."

36. This and other examples are in 2 Plowden at 465-67, 75 Eng. Rep. at 695-98.

37. 2 Plowden at 466, 75 Eng. Rep. at 698 (footnotes omitted); see Baade, supra note 22 , at 74-78, 84-86, for other cases to the same or similar effect.

38. 4 Mathew Bacon, A New Abridgment of the Law, 649 (6th ed. 1793); see id. at 643-49 (similar). For other treatises to the same effect, see A Discourse upon the Exposition \& Understanding of Statutes 140-41 (Samuel E. Thorne ed., Huntington Library Press I942) (1567); Sir Edward Coke, The First Part of tbe Institutes of the Lawes of England: Or, A Commentarie on Littleton $\$ 21$, at 24v (1628) [hereinafter Coke, Institutes]; Christopher Hatton, A Treatise Concerning Statutes or Acts of Parliament and the Exposition Thereof 29-30 (I677) (ca. I570); Christopher St. German, Doctor and Student 97 (T.F.T. Plucknett \& J.L. Barton eds., Selden Society 1974) (1528); Thomas Wood, An Institute of the Laws of England 8-10, 541 (facsimile reprint, Garland Publishing 1979) (1724); see also Samuel von Pufendorf, De Officio Homiis et Civis Juxta Legem Naturalem ch. 17, at 83 (James Brown Scott ed., 1927) (1682) (articulating similar canons in European treatise). Pufendorf was known to and relied upon by the Framers. See Helen K. Michael, The Role of Natural Law on Early American Constitutionalism: Did the Founders Contemplate Judicial Enforcement of "Unwritten" Individual Rights?, 69 N.C. L. Rev. 421, 427 (1991). 
example, Blackstone's Commentaries were more text-oriented than the earlier treatises. His eclectic theory of statutory interpretation started with the words of the statute and generally considered other context only if the words were "dubious." 39 "The fairest and most natural method to interpret the will of the legislator, is by exploring his intentions at the time when the law was made, by signs the most natural and probable." 40 This language might be read as an early version of the faithful agent theory or the plain meaning rule, ${ }^{41}$ but such readings would be anachronistic. The passage clearly provides no support for the modern idea that judges should implement the subjective expectations of legislators, the most obvious version of faithful agent theory. When early English writers deployed terms of intent or intentions, they were typically speaking of an objective standard of legal reasonableness rather than the actual expectations of the legislators. ${ }^{42}$ Nor does the passage support a simple theory of judges as nothing more than agents of the legislature. To the extent Blackstone saw judges as agents (which is doubtful), they were agents of the common law as much as agents of Parliament.

The quoted passage might more plausibly be linked to the modern plain meaning rule, but other passages in the Commentaries point in different directions. For example, Blackstone readily agreed that equity permits "correction of that, wherein the law (by reason of its universality) is deficient." 43 Thus, "where words bear either none, or a very absurd signification, if literally understood, we must a little deviate from the received sense of them." 44 His example was the famous refusal to apply a Bolognese law against public bloodletting to the surgeon who opened a vein of a person stricken on the street. ${ }^{45}$ More generally, Blackstone reasoned that narrowing constructions were desirable:

since in all laws, all cases cannot be foreseen or expressed, it is necessary that when the general decrees of the law come to be applied to particular cases, there would somewhere be a power

39. 1 William Blackstone, Commentaries on the Laws of England *59-*61.

40. Id. at $* 59$.

41. See Manning, Equity of the Statute, supra note 8, at 35 (reading the language in text as reflecting the faithful agent theory but noting Blackstone qualified any such suggestion).

42. See H. Jefferson Powell, The Original Understanding of Original Intent, 98 Harv. L. Rev. 885, 894-96 (1985); accord Baade, supra note 22, at 77-81; Manning, Equity of the Statute, supra note 8 , at $34-35$.

43. 1 Blackstone, supra note 39 , at $* 61$ (quoting Grotius).

44. Id. at $* 60$.

45. Id. at *61. The quotation and example in the text can be read consistently with the new textualism, which admits an "exception" for statutory plain meanings that are "absurd," but not for those which are merely "unreasonable." See Jonathan Siegel, What Statutory Drafting Errors Teach Us About Statutory lnterpretation, 69 Geo. Wash. L. Rev. (forthcoming Spring 2001) (manuscript on file with the Columbia Law Review) (exploring the problems and paradoxes the absurd-result exception creates for textualism). 
vested of defining those circumstances which (had they been foreseen) the legislator himself would have expressed. ${ }^{46}$

In such cases, he urged judges "to expound the statute by equity" and to reject unreasonable consequences "where some collateral matter arises out of the general words" of a statute. ${ }^{47}$ As Blackstone was the colonists' main authority on English law, ${ }^{48}$ the ameliorative power of courts was well-known to American lawyers on the eve of the Revolution and during the founding period.

\section{B. Suppletive Power (and More on the Ameliorative Power)}

As noted above, Plowden saw two faces of equity: One trimmed back the application of statutes that were too broadly phrased to fit the circumstances of a case, the other extended statutes to similarly situated cases, "[s]o that when the words of a statute enact one thing, they enact all other things which are in the like degree." 49 Thus, equitable interpretation allowed judges also to expand a statute beyond its words; this is, properly called, the equity of the statute. Plowden thoroughly approved. Thus:

in order to form a right judgment when the letter of a statute is restrained, and when enlarged, by equity, it is a good way, when you peruse a statute, to suppose that the law-maker is present, and that you have asked him the question you want to know touching the equity, then you must give yourself such an answer as you imagine he would have done, if he had been present. ${ }^{50}$ This kind of language might be read to reflect some kind of a faithful agent theory of statutory interpretation-but not the kind of faithful agent modern textualists have in mind.

Soon after Plowden's commentary, the Exchequer applied this suppletive power in Heydon's Case. ${ }^{51}$ A statute adopted by Henry VIII listed

46. 1 Blackstone, supra note 39 , at $* 61$.

47. 1d. at $* 91$.

48. Bernard Bailyn, The 1deological Origins of the American Revolution 31 (1967). Unlike the other English treatises and case reports, the Commentaries were published in America, first in Philadelphia by Robert Bell (1771), then in Worcester by Isaiah Thomas (1790), and then (an edition edited by St. George Tucker) in Philadelphia by William Young Birch and Abraham Small (1803).

49. Eyston v. Studd, 2 Plowden 459, 467, 75 Eng. Rep. 688, 698 (K.B. 1574). "Equity is the efficacious direction of the words of the law, when a thing is brought within the words of the law, so that all things of the same kind will be treated in the same way by the words." 1d. (author's translation from the Latin original).

50. 2 Plowden at 467,75 Eng. Rep. at 699. This is a paraphrase from Aristotle, Nichomachean Ethics 144-45 (Terence lrwin trans., Hacke Publ'g Co. 1985) (n.d.). For a similar appropriation of Aristotle, see 2 Pufendorf, supra note 38, at 85 . As Baade, supra note 22 , at 79-81, points out, this is the famous casus omissus that civil law urged to be filled in by statutory analogy and that English judges in the early modern era attempted to resolve by the application of "equity of the statute." See also Corry, supra note 26, at 298 (discussing the casus omissus problem).

51. 76 Eng. Rep. 637 (Ex. 1584). 
specific property transfer devices that would be disregarded if used to avoid the king's seizure of Church property. The statute did not list copyhold interests, which had been used to transfer Church property in the case at hand. Thus, the court was faced with a classic equity of the statute problem: Should the law's gap be filled in according to equity? The court laid out its theory of interpreting statutes. First, consider the common law, the "mischief" that the common law did not solve, and the remedy devised by the legislature. Then, judges should "make such construction as shall suppress the mischief, and advance the remedy, and to suppress subtle inventions and evasions for continuance of the mischief." ${ }^{2}$ Because the statute of Henry VIII sought to block evasions of the royal confiscations, the judges extended its ambit to include property interests that had been inadvertently omitted. Like Plowden, the judges in Heydon's Case followed equitable interpretation to help the legislator accomplish all he was trying to accomplish, but no more than was justified by his original goal. Oddly, the judges did not mention the equity of the statute.

Heydon's Case was a celebrated decision, and the suppletive power it exemplified and Plowden defended was often deployed by English judges and celebrated by the commentators. ${ }^{53}$ Not only did Blackstone refer favorably to Heydon's Case as an important statutory interpretation precedent, ${ }^{54}$ but he adopted this form of the mischief rule: "[T] he most universal and effectual way of discovering the true meaning of the law, when its words are dubious, is by considering the reason and spirit of it ... for when this reason ceases, the law itself ought likewise to cease with it." 55 Contrast this with Plowden's statement of the suppletive power. Not only did Blackstone limit the power to instances where the "words are dubious," but he phrased the mischief rule in a way that was decidedly ameliorative. This tilt toward the ameliorative over suppletive version of courts' equitable powers in statutory interpretation may have reflected the new English political balance of power in the eighteenth century. After the Glorious Revolution in 1688, Parliament was the primary lawmaking authority, overshadowing both the judiciary and the monarchy, and its words needed to be taken seriously.

52. Id. at 638 .

53. See Bacon, supra note 38, at 650-51 (citing Heydon's Case for claim that judges should redress the "Mischief," guard against "all subtle 1nventions and Evasions" by private persons "for the Continuance of the Mischief," and "give Life and Strength" to the public "Remedy"); Coke, Institutes, supra note 38 , at *24v (equity allows judges to extend statutes to unforeseen cases "within the same mischiefe"); Hatton, supra note 38 , at 66 ("[M]lost of those Statutes Penal ... devised ... to remedy a great mischief in the Common-weal, are extended by Equity unto cases . . . [within the] Reason with the Staute established."). Compare Popkin, Statutes in Court, supra note 21, at 14-15 (broad view of Heydon's Case), with Thorne, supra note 22, at 214-17 (1936) (viewing Heydon's Case as influential but not as bold as Popkin et al. view it).

54. 1 Blackstone, supra note 39 , at $* 87$.

55. Id. at $* 61$. 
The tilt also reflects a new relationship between citizen and state that developed in the early modern era. As regulatory statutes proliferated in England, people grew nervous about their potentially disruptive application. This anxiety gave English judges a new source of power-to stand as guardians of the traditional liberties of Englishmen against legislative intrusions. ${ }^{56}$ The canon that "all acts which restrain the common law ought themselves to be restrained by exposition" became entrenched around this time. ${ }^{57}$ More dramatically, this period saw the flourishing of the rule of lenity. Plowden had said that penal laws should not receive different treatment from civil ones, ${ }^{58}$ but Bacon opined that "penal laws are to be construed strictly; yet even in the Construction of these the Intention of the Legislators ought to be regarded," 59 and Blackstone treated it as settled that "[p]enal statutes must be construed strictly." 60 Consistent with the emerging scholarly consensus, English judges in the seventeenth and eighteenth centuries vigorously checked the expansion of criminal (capital) laws not only by construing them narrowly but even in some cases by essentially nullifying them through the stingiest reading of penal words. ${ }^{61}$

\section{Voidance Power}

The third power of courts was one suggested by Sir Edward Coke in Bonham's Case. ${ }^{62}$ A statute prohibited the unlicensed practice of medicine and vested doctors themselves with the authority to judge whether a violation had occurred. Dr. Bonham challenged the application of the statute to him, on the ground that it violated the fundamental law of the land, which entitled him to be judged by unbiased persons. Judge Coke agreed with Bonham and memorably said:

in many cases the common law will controul Acts of Parliament, and sometimes adjudge them to be utterly void: for when an Act of Parliament is against common right and reason, or repugnant, or impossible to be performed, the common law will controul it, and adjudge such Act to be void. ${ }^{63}$

He then construed the law to be inapplicable to Bonham.

56. During that period the common law was protected by "a niggardly exposition of every legislating word." Frederick William Maitland, English Law, in 9 Encyclopaedia Britannica 600, 605 (11th ed. 1910).

57. See Baade, supra note 22, at 90 .

58. Eyston v. Studd, 2 Plowden 459, 467-68, 75 Eng. Rep. 688, 699-700 (K.B. 1574).

59. Bacon, supra note 38 , at 652 ; see generally id. at 651-52 (discussing penal statutes).

60. 1 Blackstone, supra note 39 , at $* 88$.

61. The main line of cases are those construing Parliament's attempted narrowing of the "benefit of clergy" in ways that preserved it as a defense to the death penalty. See J.M. Beattie, Crime and the Courts in England, 1660-1800, at 430 (1986); Livingston Hall, Strict or Liberal Construction of Penal Statutes, 48 Harv. L. Rev. 748, 750-51 (1935).

62. College of Pbysician's (Dr. Bonham's) Case, 77 Eng. Rep. 646 (C.P. 1609).

63. Id. at 652. 
Legal historians have long debated what to make of Bonham's Case. It might be read as simply an example of judges' ameliorative power-the canon that statutes in derogation of the common law should be narrowly construed or even an early form of the canon that statutes should be interpreted to avoid absurd results. ${ }^{64}$ That Coke did not land in parliamentary hot water for his declaration suggests that this was the contemporary understanding of his statement. But the dictum in Bonham's Case could also be read more broadly for the proposition that judges had the power to void statutes violating fundamental law. ${ }^{65}$ In that event, the holding of the case is an early version of the canon that statutes should be interpreted to avoid invalidity or unconstitutionality.

The triumph in England, first of parliamentary supremacy and later of parliamentary sovereignty, required a narrow reading of Bonham's Case. ${ }^{66}$ Blackstone, for example, accepted the holding of the case when he urged that a statute vesting judicial power in a private person should not be extended to cases where he is a party, "because it is unreasonable that any man should determine his own quarrel," ${ }^{67}$ But he rejected the dictum, saying that:

[1]f we could conceive it possible for the parliament to enact, that he should try as well his own causes as those of other persons, there is no court that has power to defeat the intent of the legislature, when couched in such evident and express words, as leave no doubt whether it was the intent of the legislature or no. ${ }^{68}$

He was willing, however, to say that, "acts of parliament that are impossible to be performed are of no validity; and if there arise out of them collaterally any absurd consequences, manifestly contradictory to common reason, they are, with regard to those collateral consequences, void." 69

64. See Samuel Thorne, Dr. Bonham's Case, 54 Law Q. Rev. 543, 544-45, 548 (1938).

65. See Barbara A. Black, The Constitution of Empire: The Case for the Colonists, 124 U. Pa. L. Rev. 1157, 1207-08 (1976); see generally Theodore F.T. Plucknett, Bonham's Case and Judicial Review, 40 Harv. L. Rev. 30, 30 (1926) (analyzing Coke's opinion, contemporary reactions, and its subsequent influence).

66. The distinction in text was suggested to me by Professor Martin Flaherty: After the Glorious Revolution of 1688, Parliament was the supreme body in English government, but it was only in the second half of the eighteenth century that Parliament came to be seen as the embodiment of sovereignty. See, e.g., Black, supra note 65, at 1210-11 (making parliamentary sovereignty argument); cf. Martin S. Flaherty, Note, The Empire Strikes Back: Annesley $v$. Sherlock and the Triumph of linperial Parliamentary Supremacy, 87 Colum. L. Rev. 593, 598 (1987) (reviewing debate over argument).

67. 1 Blackstone, supra note 39 , at $* 91$.

68. Id.

69. Id. The 1809 annotated edition of Blackstone added this note: "If an act of parliament is clearly and unequivocally expressed, with all deference to the learned Commentator, I conceive it is neither void in it's direct nor collateral consequences, however absurd and unreasonable they may appear." I Sir William Blackstone, Commentaries on the Laws of England *91 11.(21) (Edward Christian ed., 15th ed., 
Consistent with the notion of parliamentary sovereignty and the decline of the dictum in Bonham's Case in English jurisprudence, English jurists by the late eighteenth century were at least rhetorically disavowing the equity of the statute and other forms of equitable interpretation. ${ }^{70}$ As one put it in 1785, "[W]e are bound to take the Act of Parliament, as they have made it: a casus omissus can in no case be supplied by a Court of Law, for that would be to make laws ...."71 Manning's explanation is that once modern ideas about legislative supremacy and the limited role of the judiciary took hold, text-based rhetoric gained in favor, and equitable interpretation all but died out. This is important, he argues, because the same thing was happening in America: Legislative supremacy and separation of judicial from lawmaking power led to the triumph of the plain meaning rule in the United States just as it had in the United Kingdom. ${ }^{72}$

The matter is much more complicated. Professor William Popkin's study of English cases concludes that the shift was just rhetorical: Judges continued to construe laws equitably, but under the cover of plain meaning rhetoric. ${ }^{73}$ Such a rhetorical shift may nonetheless have been significant if it reflected a new understanding of the proper role of courts in statutory cases, and so it might have. But no one has rigorously studied the English cases as a whole to determine, more systematically, why judicial rationalization shifted from equitable justifications to literalist ones. There may be simple Weberian reasons for greater emphasis on statutory words over the centuries spanning the early modern to the beginning of the current era: Modernization of society and education brought with it greater focus on logos (the word) and professionalization of functions. ${ }^{74}$ Over time, this increasing textual focus and professionalization required

London, A. Strahan 1809). This annotation reflects the further entrenchment of parliamentary sovereignty, see supra note 66.

70. Manning, Equity of the Statute, supra note 8, at 53.

71. Jones v. Smart, 99 Eng. Rep. 963, 967 (K.B. 1785); see also Colehan v. Cooke, 125

Eng. Rep. 1231, 1233 (C.P. 1742) holding that:

When the words of an Act are doubtful and uncertain, it is proper to inquire what was the intent of the Legislature: but it is very dangerous for Judges to launch out too far in searching into the intent of the Legislature, when they have expressed themselves in plain and clear words.

72. The plain meaning rule assumed its modern form in both countries no later than World War I. See Caminetti v. United States, 242 U.S. 470, 485 (1917); Vacher \& Sons, Ltd. v. London Soc'y of Compositors, 1913 A.C. 107, 121 (H.L.) (Lord Atkinson).

73. Popkin, Statutes in Court, supra note 21, at 19.

74. I am referring to Max Weber's thesis that modernization carries with it a movement from rewards based on status and personal qualities to those based on merit and objective or professional qualities. See 3 Max Weber, Economy and Society: An Outline of Interpretive Sociology 998-1002 (Guenther Roth \& Claus Wittich eds., Hans Gerth \& C. Wright Mills trans., Bedminster Press 1968) (1956) (noting that the modern phenomenon of bureaucratization, especially in capitalist societies, brings with it the need to dispense rewards based on individual merit and expertise). This material is also widely available in From Max Weber: Essays in Sociology 196, 240-44 (H.H. Gerth \& C. Wright Mills eds. \& trans., 1958). 
judges to present themselves less as wise men applying precepts and more as experts of the complex mechanism of law or even as mere wordsmiths. This cultural theory could underlie Popkin's suggestion, but the matter would require serious examination of the culture and biography of judges during the period. ${ }^{75}$

Additionally, without a more systematic examination, it is unclear whether the new rhetoric was actually dominant or even ascendant in the late eighteenth century. The most famous statutory interpreter of that period was Lord Mansfield, Chief Justice of the Court of King's Bench (1756-1788) - and he construed statutes almost as dynamically as he reconfigured the common law. ${ }^{76}$ This phenomenon was not limited to Mansfield's court, for there was a general concern in England that there were too many statutes that swept too broadly. This phenomenon justified continuing judicial narrowing of statutes in a variety of cases. ${ }^{77}$ The work of the leading historians supports the hypothesis that even if judges were more cautious about asserting their suppletive powers (the equity of the statute), they remained unabashed and sometimes bold in asserting their equitable powers of amelioration. Just as Blackstone's libertarian treatise repeatedly endorsed judges' ameliorative powers and neglected their suppletive powers, English practice throughout the eighteenth century vigorously reflected the ameliorative power of judges to narrow statutes that were in derogation of the common law, ${ }^{78}$ that imposed penalties and especially death for misconduct, ${ }^{79}$ or that were otherwise unreasona-

75. For a similar thesis regarding American judges, see Gordon S. Wood, The Origins of Judicial Review Revisited, or How the Marshall Court Made More out of Less, 56 Wash. \& Lee 1. Rev. 787, 801-02 (1999) [hereinafter Wood, Origins].

76. See James Oldham, From Blackstone to Bentham: Common Law Versus Legislation in Eighteenth-Century Britain, 89 Mich. L. Rev. 1637, 1647-48, 1651-56 (1991) (describing Mansfield asserting both suppletive and ameliorative powers in statutory cases, even amid criticism).

77. See David Lieberman, The Province of Legislation Determined: Legal Theory in Eighteenth-Century Britain 16-20, 28, 52-72 (1989) (discussing the proliferation of mangled statutes in eighteenth-century England and Blackstone's disdainful attitude toward them, with judges being the main salvation by protecting the common law against bad statutes).

78. See, e.g., Rex v. Moreley, 97 Eng. Rep. 696, 697 (K.B. 1760) (holding that certiorari was proper because text of statute did not expressly narrow court's jurisdiction); Arthur v. Bokenham, 88 Eng. Rep. 957, 958 (C.P. 1709) (presuming act of Parliament does not alter common law, unless clear language to the contrary); see generally Sir Peter Benson Maxwell, The Interpretation of Statutes 254-57 (Sir Gilbert H.B. Jackson ed., 8th ed. 1937) (citing a variety of cases, from sixteenth to nineteenth centuries, for idea that statutes are construed not to impose restrictions unknown at common law).

79. E.g., Rex v. Beaney, 168 Eng. Rep. 874, 874 (K.B. 1820) (holding that capital punishment for "stealing horses" not applicable to stealing a "colt"); Rex v. Seas, 168 Eng. Rep. 255, 255 (K.B. 1784) (holding capital punishment for stealing "any goods, wares, or merchandises" from a stable not applicable to theft of a coachman's coat from a stable); Rex v. Kemp, 168 Eng. Rep. 213, 214 (K.B. 1780) (holding that stealing a tree at around 9 p.m. not to be theft at "night time" because it was still light outside); 1 Blackstone, supra note 39 , at *88 (noting that capital punishment for stealing "sheep or other cattle" was held inapplicable to theft of cattle). 
ble. ${ }^{80}$ Rather than demonstrating a decisive turn from equity to law, the English authorities better support a turn from judicial supplementation to judicial protection of liberties based on the common law and, perhaps more important, a rhetorical turn away from the language of equity that did not necessarily abandon its spirit.

Finally, there was a political and constitutional reason for English judges to trumpet their adherence to Parliament's precise legal commands and to minimize talk of equity. The conditions supporting aggressive judicial statutory interpolations in the sixteenth and seventeenth centuries included the fragmentation of the national government in England. So long as the Crown and Parliament were contentious rivals for control of government, few statutes were enacted, and common law judges had a lot of freedom to impose the policies of the common law onto existing statutes. ${ }^{81}$ Those conditions of judicial independence from political control eroded once Parliament established itself as the supreme lawmaking body in the first half of the eighteenth century and ended as the Westminster model of parliamentary sovereignty was taking shape in the second half. By the mid-nineteenth century, the Westminster model was gospel, and text-based and faithful agent theories reigned supreme as the rhetoric of statutory interpretation in England. ${ }^{82}$ Thus, the notion that English judges must avoid the appearance of exercising equitable "discretion" depended on features of England's constitution along Westminster lines that were radically different from the assumptions of the U.S. Constitution of 1789: The English constitution understood sovereignty to reside in Parliament, which had plenary lawmaking power, while the U.S. Constitution understood sovereignty to reside in "We the People," with lawmaking diffused among two chambers of Congress, the President, and the Supreme Court, and limited by the customary rights of the people. ${ }^{83}$

\section{Statutory 1nterpretation During the Founding} Period, 1776-1791

However one reads them, the English materials are only a start in discerning the understandings (if any) about the judicial power generally held by the Americans who threw off English rule and then drafted vari-

80. E.g., Foone v. Blount, 98 Eng. Rep. 1188, 1191 (K.B. 1776) (refusing to apply statutory bar against Catholics' taking land by devise to prohibit the payment of debts by devise to Catholic creditors).

81. See Douglass C. North \& Barry R. Weingast, Constitutions and Commitment: The Evolution of Institutions Governing Public Choice in Seventeenth-Century England, $49 \mathrm{~J}$. Econ. Hist. 803, 812-14 (1989).

82. See 3 John Phillip Reid, Constitutional History of the American Revolution: The Authority to Legislate 302 (1991); see also Jenna Bednar et al., A Political Theory of Federalism, in Constitutional Culture and Democratic Rule (John Ferejohn et al eds., 2001) (collecting other sources).

83. See 4 John Phillip Reid, Constitutional History of the American Revolution: The Authority of Law 4-5 (1993). 
ous constitutions. Gordon Wood, the leading historian of the Revolutionary period, has authoritatively argued that the colonists on the eve of the Revolution were committed both to the notion that law should be written down by the popularly elected legislature and to James Otis's idea that "righteousness should be the basis of law." ${ }^{4}$ During the Revolution, the former idea was dominant and manifested itself in expressions of distrust of judicial discretion generally and equity-based interpretation in particular. Civic republicans put their faith in the people, acting through legislatures and juries, and sometimes expressed scorn for the elites of the judiciary. As to interpretation, the republicans sometimes advocated clear rules, and some of them were hostile to the perceived discretion entailed in judges' equitable constructions: " $[\mathrm{N}] \mathrm{o}$ axiom is more dangerous than that the spirit of the law ought to be considered, and not the letter," said one patriot in $1777 .{ }^{85}$ Thomas Jefferson later wrote, "Relieve the judges from the rigour of text law, and permit them, with pretorian discretion, to wander into it's [sic] equity, and the whole legal system becomes uncertain." ${ }^{86}$ Consistent with these attitudes, legislatures during the Revolution sought to impose popular limits on judges through controlling their appointments and salaries, restricting equity jurisdiction and the applicability of English common law, and empowering juries to decide the law as well as the facts in cases. ${ }^{87}$

Few revolutionary lawyers went as far as Jefferson in criticizing Blackstone and Mansfield, and his codification movement yielded results contemporaries recognized as disappointing and alarming. None of the leading historians of the period suggests that English practice or equitable interpretation became irrelevant, notwithstanding popular attacks. lnstead, the historiographical consensus is that the state republican experiments in legislative supremacy during the 1770s gave way in the 1780s to an ideology that viewed the fundamental law features of the English and colonial background as a building block for liberty here, and that appreciated the role of judges, even in their equity capacity, as the guarantors of that liberty. ${ }^{88}$ The work of legislative assemblies revealed that

84. Wood, Creation, supra note 14 , at $292-96$.

85. Id. at 301 (quoting "a writer in I777"); see John Choon Yoo, Who Measures the Chancellor's Foot? The Inherent Remedial Authority of the Federal Courts, 84 Cal. L. Rev. 1121, 1 I5I-53 (1996) [hereinafter Yoo, Chancellor's Foot]. But cf. Cynthia S. Jordan, "Old Words" in "New Circumstances": Language and Leadership in Post-Revolutionary America, $40 \mathrm{Am}$. Q. 491, 501-02 (1988) (arguing that judiciary reserved "the majesty of national authority"-the task of interpreting Constitution (quoting Hamilton from The Federalist No. 16, at 116 and citing The Federalist No. 78, at 465))

86. Letter from Thomas Jefferson to Philip Mazzei (Nov. I785), in 9 The Papers of Thomas Jefferson 67, 71 (Julian P. Boyd ed., 1954). This Jeffersonian sentiment was voiced at a time when it was already becoming marginalized.

87. See Popkin, Legislation, supra note 21, at 37-41; Wood, Creation, supra note 14, at $160-61$.

88. See Robert E. Stalhope, The Roots of Democracy: American Thought and Culture, 1760-1800, at 121 (1990); Gordon S. Wood, The Radicalism of the American Revolution 322-25 (I99I); Jack N. Rakove, The Origins of Judicial Review: A Plea for New 
early theorists had overestimated the people's capacity for civic virtue, as those assemblies adopted statutes that nakedly invaded established property interests and personal liberties and openly meddled in adjudications. Some thoughtful observers (most notably, James Madison) concluded that the proliferation of statutes by legislatures and their occasional meddling in adjudications revealed that "popular" organs posed the most serious threats to people's accustomed liberties. ${ }^{89}$ As Professors Wood and Rakove have recently (re)emphasized, the period before the Philadelphia Convention witnessed a transformation in attitudes toward judges. The delegations who convened in Philadelphia were friendly to the idea that an independent judiciary should not only be a co-equal branch of balanced government, but also a needed check against legislative excesses. ${ }^{90}$

Based upon the standard historiographical account, my hypothesis is that judicial practice in the 1780s and 1790s would have followed the English authorities in tempering statutory words with factual, common law, and other contexts. To discern the norms of statutory interpretation, 1 read the reported decisions of the courts in Connecticut, New Jersey, Pennsylvania, Virginia, North Carolina, and South Carolina between 1783 and $1795,{ }^{91}$ as well as the eight reported decisions of the federal court of

Contexts, 49 Stan. L. Rev. 1031, 1060-64 (1997) [hereinafter Rakove, Origins of Judicial Review]. All these sources elaborate on the ideas originally laid out in Wood, Creation, supra note 14, at 453-63. See also Carlos E. González, Reinterpreting Statutory 1nterpretation, 74 N.C. L. Rev. 585, 636-59, 688-91 (1996) (surveying historical evidence supporting Wood thesis and applying that evidence to criticize "honest agent" theories of statutory interpretation).

89. See Charles Grove Haines, The American Doctrine of Judicial Supremacy 70-71 (1959); Rakove, Original Meanings, supra note 14, at 44-50; Wood, Creation, supra note 14, at 302-03; Edward S. Corwin, The Progress of Constitutional Theory Between the Declaration of 1ndependence and the Meeting of the Philadelphia Convention, $30 \mathrm{Am}$. Hist. Rev. 511, 534 (1924-1925). Even Jefferson grudgingly came to admit that judicial independence was needed not just to assure a neutral rule of law, but also to check legislative abuses. See Wood, Creation, supra note 14, at 303.

90. See Rakove, Origins of Judicial Review, supra note 88, at 1060-64; Wood, Origins, supra note 75, at 792-96. The shift in prevailing mood or ideology from the revolutionary period to one of nation-building is only a shift-and the gentler attitudes toward equitable interpretation are only relative. You can easily find defenses of equitable interpretation during the Revolution. Just as easily, you can find indictments of equitable interpretation in the 1780s, as Manning has done, but according to Wood's account such indictments were the minority position by then.

91. The array in text represents almost half of the original 13 states, all three regions (South, Mid-Atlantic, and New England), and all of the major states (including the states whose ratification debates were most important and intense), except for New York and Massachusetts. I did not read New York's highest court decisions, because of the possibility that they were affected by the participation of the judges in that state's Council of Revision. See infra notes 191-202. I do discuss the most famous lower court decision in that state, Rutgers $v$. Waddington, see infra notes 169-180 and accompanying text, because it was wellknown and involved Alexander Hamilton. Quincy's Reports include Massachusetts cases for the period 1761-72, but then there is a gap before Massachusetts cases are reported again, with the Massachusetts Reports commencing in 1804. (As for the other New 
appeals. ${ }^{92}$

Because many judicial decisions of this period were unreported and some were unwritten, ${ }^{93}$ the cases I read are not a complete sample even for the six states surveyed. I do not offer the following analysis as a random sample demonstrating judicial methodology in the average case, however. Instead, I am invoking the cases discussed in this Part to show that American judges after the Revolution continued to exercise the suppletive, ameliorative, and voidance powers exercised by English judges. The reasoning in the reported decisions reveals that judges considered statutory goals and spirits, the common law, natural law and common sense, and constitutional values relevant to the application of statutes; the results in the cases demonstrate that judges were often willing to bend or break the letter of the law to accommodate norms and practices. These generalizations hold for all six states, and there is every reason to believe that they would hold for other states as well. ${ }^{94}$ Moreover, the case law collectively, and some of the individual cases, constituted a source of knowledge about what the judicial power would include. This source of knowledge would have been accessible to the delegates at the Philadelphia and the state ratifying conventions, many of whom were lawyers and

England states, New Hampshire's cases were not reported in Smith's Reports until 1796, and Rhode 1sland did not have a professional judiciary.).

For the period 1776-1796, many Connecticut judicial decisions (mainly by lower courts) are reported in volume 1 of Kirby's Reports (1785-88) and volumes 1-2 of Root's Reports (1764-1797); New Jersey decisions (both lower and highest court) are reported in volume 1 of Coxe's N.J. Law Reports (1790-1795); Pennsylvania decisions (mainly by lower courts) are reported in volumes 1-2 of Dallas' U.S. Reports; North Carolina decisions (mainly by the highest court) are reported in volumes 1-2 of Haywood's Reports; South Carolina decisions (mainly by the highest court) are reported in volumes 1-2 of Bay's Reports; Virginia decisions (mainly by the highest court) are reported in scattered portions of volumes 1-10 of the Virginia Reports.

92. These cases are reported at 2 U.S. (2 Dall.) 1-42. Although there was no federal judicial power created by the Articles of Confederation, Article IX did give Congress powers of "appointing courts for the trial of piracies and felonies committed on the high seas and establishing courts for receiving and determining finally appeals in all cases of captures." Articles of Confederation art. IX. This provision ratified actions Congress had previously taken to vest jurisdiction over capture appeals in a specially appointed committee. In 1780 Congress created the Court of Appeals, a judicial body to hear appeals in prize and capture cases. See Penhallow v. Doane's Administrators, 3 U.S. (3 Dall.) 44, 64-69 (1787) (upholding authority of Congress to establish the court, both before and after the Articles were ratified); cf. Federal Courts Prior to the Adoption of the Constitution, 131 U.S. app. xix, xix-xxvii (1889). The judges were chosen by Congress, and the turnover was brisk during the 1780s. See id. at xxv-xxvii. In 1786, Congress abruptly cut off the judges' salaries! See id. at xxviii. That was the end of this court.

93. John H. Langbein, Chancellor Kent and the History of Legal Literature, 93 Colum. L. Rev. 547, 571-74 (1993).

94. See infra notes 169-176 and accompanying text (discussing the New York decision in Rutgers); see also Timothy A. Lawrie, Interpretation and Authority: Separation of Powers and the Judiciary's Battle for Independence in New Hampshire, 1786-1818, 39 Am. J. Leg. Hist. 310, 312-13 (1995) (demonstrating that early New Hampshire judicial practice was much influenced by equitable considerations). 
some of whom were lawyers and judges personally involved in cases described below. Without doubt, there is continuity between judicial construction of statutes in the United States in the 1780s and early 1790s and English practice as reflected in Blackstone and Bacon. Many American judges in the founding period interpreted statutory words more equitably than English judges-excepting Lord Mansfield!-in the same period. ${ }^{95}$

Like the English judges and Blackstone, American judges paid close attention to both the letter and spirit as well as legal context of statutes. ${ }^{96}$ For example, the federal case of Miller $v$. The Ship Resolution applied congressional "ordinances" to determine whether the ship and its cargo were confiscable as prizes. ${ }^{97}$ The main ordinance provided that "after a capture and occupation for twenty-four hours the property captured shall be prize." 98 Although the law was broadly written, the court ruled that Congress did not intend to authorize seizure of neutral ships or cargo. "The ordinance of Congress certainly speaks of a legal capture; to admit a different construction would be a violence both to the terms and spirit, or intention, of it." 99 The court supported this reading of capture on the grounds that the ordinance used it with the term prize, which in maritime common law meant enemy cargo or ships, and that a contrary reading would violate the law of nations. ${ }^{100}$ Moreover, the court considered subsequent ordinances instructing American commanders not to seize neutral vessels nor even to "seize or capture" enemy goods aboard neutral vessels unless it were "contraband goods \&cc."101

Miller gave a narrow reading to an ordinance, but in the next case the federal judges expanded upon the letter of a related ordinance that was written too stingily. In Darby $v$. The Brig Erstern, the state court had acquitted the brig and its cargo as neutral. ${ }^{102}$ The claimant appealed on the ground that the neutral vessel was carrying provisions to an enemy place under siege. The brig relied on a congressional ordinance which stated: "You shall permit all neutral vessels freely to navigate on the high

95. Another qualification was suggested to me by John Langbein: some state judges of this period were not lawyers, and some judges who were lawyers were not learned in the law. See Langbein, supra note 93, at 566-67. I doubt this fact lends any support to the Manning claim that judicial power in $\mathbf{I 7 8 9}$ was understood to reflect the faithful agent theory but it is potentially relevant to generalizations about state practice.

96. I use "letter" and "spirit" rather than "text" and "purpose" of statutes because the former terms were the ones preferred by contemporaries. In my view, it is anachronistic to talk of "textualist" approaches to statutory interpretation in the I780s. The cases often invoked legislative "intent," but not in the way we use that term today. Intent was deployed generally to emphasize the directive nature of statutes and carried with it no suggestion about legislators specific expectations or their general goals. See supra note 42 and accompanying text.

97. 2 U.S. (2 Dall.) I (Fed. Ct. App. I781), modified on reh'g, id. at I9.

98. Id. at 3 .

99. Id. at 3-4.

I00. Id. at 4.

101. Id. at 18 (invoking the Ordinance of April 7, 1781, Instructions 3 \& 4).

I02. 2 U.S. (2 Dall.) 34, 34 (Fed. Ct. App. 1782). 
seas or the coasts of America, except such as are employed in carrying contraband goods, or soldiers, to the enemy."103 As provisions were not included in the statutory definition of "contraband goods," the ship maintained that its capture was not legal. But because the vessel had essentially breached its neutrality as a matter of common sense as well as international practice, the court refused to limit the law to its textual application. "Were Congress asked, whether they meant to protect from capture, a neutral ship loaded with provision, and destined for York and Gloucester, when besieged by the armies of the United States and France, no one could possibly doubt what their answer would be." 104 Note the echo of Aristotle and Plowden. ${ }^{105}$ This was a classic example of the equity of the statute concept (the suppletive power) in action.

None of the few reported federal cases adopted a follow-the-wordsnotwithstanding-the-consequences approach to statutory interpretation (the stance of some new textualists today), but at least one state case seemed to do so. In Porter $v$. Dunn, the revolutionary army seized two slaves owned by Dunn while he was consorting with the British and delivered them over to Porter as compensation for his service as a patriot officer. ${ }^{106}$ The slaves escaped and went back to Dunn; Porter sued for their return. A subsequent statute barred lawsuits against officers for the return of seized property (as the slaves were considered to be) and directed claimants to seek redress in the legislature. South Carolina Supreme Court Justice Grimke presided at trial. He told the jury that the practice of confiscating enemy property and distributing it to one's soldiers and officers was justified by neither the law of nations nor common sense. "But the act of assembly of 1784 . . places this case beyond all doubt," exonerating Porter from suit and directing "that the former owners shall apply to the legislature, and not elsewhere: which seems to legalize all the proceedings of those officers; and, in fact, vests the property in them."107 Although Justice Grimke declined to create an equitable exception to the letter of the law, his opinion actually expanded its words, which only barred lawsuits by property owners against officers, to include Porter's case, where the officer was the plaintiff seeking the return of the slaves. Nowhere did the statute vest officers with property rights; the holding reflected the jurist's willingness to supplement the letter of the law, perhaps an unconscious nod to equity.

103. $1 \mathrm{~d}$.

104. 1d. at 34-35; see id. at 36 (discussing equitable narrowing of ordinance's exclusion from prize of anything on neutral ships except "contraband"); see also Pbile v. The Ship Anna, 1 U.S. (1 Dall.) 197, 200-01 (Pa. Comm. Pl. 1787) (describing an unreported case interpreting the same statute and refusing to apply the law "upon the strict letter," lest such construction "pervert the politic but equitable meaning of the act of Congress").

105. See supra note 35 and accompanying text.

106. 1 S.C.L. (1 Bay) 53, 53 (1787).

107. ld. at 57. 
1 found no other reported state case quite like Porter, where a court announced that a highly unreasonable application was required by the words of a statute. ${ }^{108}$ lndeed, the case's reporter opined that it would have been decided differently after the adoption of the U.S. and South Carolina Constitutions in 1789 and $1790 .^{109}$ But there were plenty of state cases where the judges simply applied statutory words, typically without extended discussion. ${ }^{110}$ For the most part, the state statutory interpretation decisions were like Miller and Darby: the judges attended to the statutory words and the whole statute, read the words in the context of the matter regulated and the spirit of the statute, and were quietly willing to narrow or expand the letter of enacted law in light of the common law, the legislative policy, common sense and good reason, and higher law norms such as the law of nations or constitutional principles. A typical statement of the interpretive task was this:

We do not consider ourselves bound by the strictly grammatical construction of the words of the act. The intention of the legislature should be our guide; or, rather, in a case of this nature, we should not hesitate to adopt a construction which the words will clearly warrant, free from those inconveniences which must flow from any other interpretation. ${ }^{11}$

108. Some of the oddities of Porter might arise from the fact that the case involved slaves, a wild-card factor in the founding period. Eighteenth-century judges had strong feelings about slavery that probably influenced their statutory constructions, much as strong feelings about race today influence judicial constructions of Title VI1. What was particularly odd about Porter, though, was that the South Carolina judge construed the law to separate slaves from their original owner, Dunn. Southern judges in other cases went out of their way to preserve longstanding slave-master relations. See, e.g., Ham v. M'Claws, 1 S.C.L. (1 Bay) 93 (1789) (per curiam) (construing law to avoid confiscation of emigrant's slaves); Turner v. Turner's Executrix, 8 Va. (4 Call) 234, 237-38 (1792) (construing various state laws to nullify jury finding that slaves had been transferred and ordering new trial). Northern judges, in contrast, went out of their way to limit conditions of servitude. See, e.g., Huntington v. Jones, 1 Kirby 33, 35 (Conn. Super. Ct. 1786) (law assigning debtors to service "being an abridgment of personal liberty, requires caution in exercise, and is not to be enlarged by implication"); Respublica v. Keppele, 2 U.S. (2 Dall.) 197, 198-99 ( $\mathrm{Pa}$. 1793) (narrowly construing indentured servant law to avoid obvious injustice).

109. In a note following the case, the reporter opined that the U.S. Constitution and the new South Carolina Constitution of 1790 would have required a different result, as the 1784 law was assertedly ex post facto. See Porter, 1 S.C.L. at 57 n.*.

110. E.g., Gregory v. Bray, 1 N.C. (Mart.) 29, 30 (1796); The Executors of Middleton v. Robinson, 1 S.C.L. (1 Bay) 58, 61 (1789); Beall v. Edmondson, 7 Va. (3 Call) 514, 520 (1790); Huntington, 1 Kirby at 35. Most of the cases simply mention particular statutes, without analysis or even quotation of their words.

111. Woodbridge v. Amboy, 1 N.J.L. 246, 247 (Sup. Ct. 1794); see also Elliott v. Richards, 1 Del. Cas. 87, 89 (C.P. 1796); Kerlin's Lessee v. Bull, 1 U.S. (1 Dall.) 175, 178 (Pa. 1786) (stating that judges interpreting statutes should consider "the words and spirit of it," long-established practice under the law, and if the intent remains unclear "what is most consonant to equity, and least inconvenient"); Warder v. Arell, 2 Va. (2 Wash.) 282, 299 (1796) (considering reason and spirit of the law as well as its "grammatical construction"). Compare Bissel v. Southworth, 1 Root 269, 270 (Conn. Super. Ct. 1791) (stating that where case is not provided for in a statute, it "must be governed by reason and justice"), with 
There is little, if anything, in this kind of approach that endorsed judicial "lawmaking," celebrated the discretion of judges to read their own preferences into statutes, or considered statutory words anything but relevant and significant. What this kind of approach did reject was a method where judges ignored or slighted the real-world, practical, common law, constitutional, and policy context in which the statutory words fit. This approach accepted and even expanded on equitable readings of statutes. Some judges said so even more explicitly. A Pennsylvania judge observed in 1787 that "the judges here, are, therefore to determine causes according to equity, as well as positive law" in order "to prevent a failure of justice."112

Manning's account consciously ignores the state and federal court experience with statutes during the founding period, for reasons that are historiographically hard to defend. ${ }^{113}$ Thus, he argues that the state constitutions then in effect did not separate the judicial from the legislative power as clearly as the U.S. Constitution later would accomplish. He overstates the differences between the federal and state constitutions, however. The state constitutions adopted in the 1770 s generally provided for a separation of the legislative, executive, and judicial personnel and authority. Indeed, the constitutions of Massachusetts, New Hampshire, Virginia, North Carolina, Maryland, and Georgia explicitly required that judges not exercise legislative or executive powers, ${ }^{114}$ while the U.S. Constitution had no such provision. ${ }^{115}$ The most prominent exception to this rule of separate functions was New York's constitution, which vested a veto of bills approved by the legislature with a Council of Revision consisting of the Governor, the Chancellor, and the Supreme Court. ${ }^{116}$ Moreover, all of the state constitutions provided some protection for judges

Bacon v. Masters, 2 Root 43 (Conn. Super. Ct. 1793) (stating that remedial statute "is to be construed liberally in advancement of the remedy and in suppression of the mischief").

112. Wood, Creation, supra note 14, at 457. Another Pennsylvanian said in 1787 that in "these more enlightened days" law should be nothing but justice, as "there cannot be anything more absurd than a distinction between law and equity." Id.

113. See Manning, Equity of the Statute, supra note 8 , at $86 \mathrm{n} .336$ (rejecting state cases because there has been no showing of (1) a uniform state practice or (2) a similar constitutional context and, in any event, (3) because any uniform state practice was inconsistent with the "express constitutional assumptions and interpretive practices that ultimately prevailed in the federal courts in the early republic."). My account in this Part shows there was overwhelming state uniformity in continuing to read statutory language equitably, and Part $V$ will show that there was continuity with early federal practice. The second objection is the best one, and 1 respond to it in the text.

114. See Popkin, Legislation, supra note 21, at $39-40$ (collecting state constitutional provisions).

I15. Madison proposed to amend the Constitution to assure that "powers delegated by this constitution, are appropriated to the departments to which they are respectively distributed," such that the judiciary could not "exercise the powers vested in the legislative or executive departments." This amendment was not adopted. See Casper, supra note 16, at 221-22.

116. N.Y. Const. of 1777 , art. III, reprinted in 2 The Federal and State Constitutions, Colonial Charters, and Other Organic Laws of the United States 1329, 1332 (Ben Perley 
against political retaliation, although the protections varied from state to state. ${ }^{117}$ Virginia and North Carolina judges, for example, were appointed by the General Assembly but enjoyed life tenure (during "good behavior") and "fixed and adequate salaries."118 New Jersey judges had limited terms and no salary protection, ${ }^{119}$ while Pennsylvania judges had limited terms and salary protection. ${ }^{120}$

In general, the texts of state constitutions reveal little basis for distinction from the federal Constitution as regards the separation of judicial from other powers. The Framers themselves defended the U.S. Constitution's separation of judicial from other powers as "a copy of the constitutions of New Hampshire, Massachusetts, Pennsylvania, Delaware, Maryland, Virginia, North Carolina, South Carolina, and Georgia."121 Manning's attempt to distinguish state court practice also rests upon an excessively narrow understanding of the national commitment to separation of powers: The U.S. Constitution sought a balance of powers rather than a complete separation of them. ${ }^{122}$ Additionally, the main ways that powers were intermingled in some of the state constitutions should have cut against equitable constructions of statutes, especially when such constructions were unpopular, as they often were. Finally, my survey of the cases demonstrates that judges in one case after another during the $1780 \mathrm{~s}$ and 1790s saw it to be their judicial duty to consider the broader legal and equitable context in which statutes were being applied, whatever the precise state constitutional context. The best example is Pennsylvania, whose 1776 constitution intermingled judicial and legislative powers a little. ${ }^{123}$ After that constitution was superseded in 1790 by a document patterned on the U.S. Constitution, ${ }^{124}$ the state courts continued to construe

Poore ed., 2d ed. Washington Govt. Printing Office 1878) [hereinafter Poore, Constitutions].

117. See Popkin, Legislation, supra note 21, at 37-39.

118. Va. Const. of 1776 , para. 12 , reprinted in 2 Poore, Constitutions, supra note 116 , at 1911; N.C. Const. of 1776, arts. XI11, XXI reprinted in 2 Poore, Constitutions, supra note 116 , at $1412-13$.

119. N.J. Const. of 1776 , art. X1I, reprinted in 2 Poore, Constitutions, supra note 116 , at 1312 .

120. Pa. Const. of $1776, \S \S 20,22-23$, reprinted in 2 Poore, Constitutions, supra note 116, at 1545. In 1790, Pennsylvania adopted a new constitution containing the same protections for judicial independence found in the federal Constitution. See id. at 1548-57.

121. The Federalist No. 81, at 484 (Alexander Hamilton) (Clinton Rossiter ed., 1961). 1n my opinion, Hamilton was exaggerating the conformities (a "copy"?) between the federal and state constitutions, but Manning exaggerates their discontinuities.

122. See Forrest McDonald, Novus Ordo Seclorum: The Intellectual Origins of the Constitution 258 (1985); M.J.C. Vile, Constitutionalism and the Separation of Powers 120-54, 160-75 (Liberty Fund, Inc. I990) (1967); Flaherty, Most Dangerous Branch, supra note 16, at 1766-67, 1784-85; Gonzalez, supra note 88, at 636, 668-91.

123. Pa. Const. of 1776 , art. 20-24, reprinted in 2 Poore, supra note 116 , at 1545-46.

124. See supra note 120. 
statutes equitably, with no abatement. ${ }^{125}$ If anything, the constitutional shift in Pennsylvania ushered in a period of particularly dynamic and equitable constructions of state law. ${ }^{126}$

As the leading historians, Wood and Rakove, have emphasized, this was a period of changing attitudes about the judiciary, but the new attitudes were emphatically favorable to forceful judicial trimming of legislative excesses. ${ }^{127}$ The main innovation, in fact, was a judicial willingness to bend statutory words to avoid clashes with constitutional principles. This willingness, too, is well-illustrated by the state cases. Any serious analysis of the historical context of the "judicial Power" vested in federal judges by the Constitution of 1787 cannot ignore the state practice. In light of those cases, there can be no doubt that the lawyers and many of the lay people debating about the "judicial Power" at Philadelphia and at the state ratifying conventions would have been aware that judges in the United States not only exercised the same kind of suppletive and (especially) ameliorative powers that Plowden conceptualized and English judges long had practiced, but laid claim to a voidance power with a vigor not seen since the days of Coke. ${ }^{128}$

\section{A. Suppletive Power}

Like the English judges in Heydon's Case and the federal judges in Darby, state judges sometimes extended statutory words to include closely related matters. In the suppletive power cases I found, judicial extensions of statutes were slight, the statutes sometimes contained arguable ambiguities in language that might have rendered them susceptible to the slight extensions, and the supplementation was respectful of the primacy of the legislature in making statutory policy. The cases, in short, suggest that the equity of the statute was not inconsistent with modern ideas about judges as interstitial lawmakers.

125. Compare, e.g., Kerlin's Lessee v. Bull, 1 U.S. (1 Dall.) 175, 178 (Pa. 1786) (invoking equity to narrow a broad statute under the 1777 constitution), with Respublica v. Keppele, 2 U.S. (2 Dall.) 197, 198 (Pa. 1793) (following a similar approach under 1790 constitution).

126. The most boldly dynamic interpretation by the Pennsylvania Supreme Court came under the 1790 constitution, in Roach v. Commonwealth, 2 U.S. (2 Dall.) 206 (Pa. 1793). See infra notes $155-159$ and accompanying text.

127. See supra note 90 .

128. Recall that 1 make no claims about how the average judge actually approached statutes; we cannot know that for sure without a deeper sample. My claim is only that the reported decisions constituted a body of knowledge that would have been accessible to the lawyers who assembled at Philadelphia in 1787 or at the ratifying conventions in 1787 through 1790 or that would have reflected the same kind of mindset as the Framers (a number of cases noted below were decided in the 1790s and are relevant for this reason). Moreover, some of the leading participants at Philadelphia and the state ratifying conventions were judges or lawyers involved in litigations yielding equitable constructions of state law. 
A particularly well-reasoned case was Executors of Barracliff $v$. Administrator of Griscom. ${ }^{129}$ Plaintiff obtained a judgment for $£ 7410$ s.; after failure of complete payment, plaintiff won a second judgment for the $£ 456 \mathrm{~s}$. $2 d$. balance. The issue was whether plaintiff was entitled to costs in the second action. A 1782 statute gave costs in "any suit for any debt or demand" when the judgment was for fifty pounds or more, but a 1747-48 statute provided for costs in "any suit or action whatsoever" where the sum was more than fifteen pounds. ${ }^{130}$ The New Jersey Supreme Court framed the inquiry as "guided by the designs and intentions of the legislature, so far as they are to be gathered from the expressions which they have employed." 131 Although the court saw the words of the law as part of the interpretive enterprise, it extended the 1782 statute-whose literal meaning would have denied plaintiffs costs in the second action-to include "superior" actions to enforce judgments. The court reasoned from three elements: the equitable policy of the earlier statute, Aristotle's notion that exceptions to general texts can be justified when unanticipated factual situations arise, and the "inconveniences" if plaintiff were denied costs. "[A]s we are not compelled by the letter, and perhaps spirit of the acts, to adopt such [an inconvenient] construction, we are of opinion that they do not apply to this case, and that the plaintiff recover his full costs." 132

The issue in Whiting $\mathcal{E}$ Frisbie $v$. Jewel was whether defendant in a Connecticut lawsuit could offer depositions which had been taken in Massachusetts. ${ }^{133}$ A statute authorized Connecticut judicial officers to "take affidavits out of court; so [long] as a notification, with reasonable time, be first made out and delivered to the adverse party ... to be present at the time of taking such affidavit." 134 The law apparently did not authorize the taking of affidavits out of state, and so the court could have refused to accept them because they fell outside the statutory authorization. The Connecticut Superior Court ruled, however, that, "[a]s to those taken out of the state, which the statute in strictness does not extend to, and which can only be admitted on the ground of their being so taken as to come fully within the equity of the statute; there ought to be notice to the adverse party or to his known agent or attorney."135 Thus, the deposition was not admitted because neither plaintiffs nor their counsel had been notified so they could participate in it. This neat little decision reflected a liberal approach to procedure statutes, but with strict attention to fairness values; equity of the statute did not authorize judges to extend laws

129. 1 N.J.L. 224 (Sup. Ct. 1793).

130. Id. at 225-26.

131. Id. at 194 .

132. Id. at 227.

133. 1 Kirby 1 (Conn. Super. Ct. 1786).

134. Id. at 2.

135. Id. at 2. But see id. (Sherman, J., dissenting) (employing a different reading of the words of the statute). 
willy nilly. One of the judges on that court in 1786 was Oliver Ellsworth, soon to be a leading pamphleteer for the proposed new Constitution and later to be Chief Justice of the United States.

In Bracken v. Visitors of William and Mary College, the issue was whether the college's Board of Visitors had the authority under the college's royal charter to abolish the longstanding chair of grammar. ${ }^{136}$ Bracken, the deposed professor, argued that the Visitors were not authorized by the charter to alter the structure established by the original trustees. William and Mary, through its counsel John Marshall, argued that the general intent of the authorizing statutes was to delegate policymaking discretion to the Visitors and that changed circumstances justified the Visitors' adoption of a plan contrary to some of the details of the educational structure that had been established pursuant to the original grant. "It was proper that this discretion should be given to the visitors, because a particular branch of science, which, at one period of time would be deemed all important, might at another be thought not worth acquiring," argued Marshall. ${ }^{37}$ "In institutions therefore, which are to be durable, only great leading and general principles ought to be immutable."138 The Virginia Court of Appeals summarily agreed. ${ }^{139}$

In addition to these interesting cases, there were a number of others where state courts construed statutes liberally, extending their ambit, usually just slightly, in order better to solve the mischief the legislature had targeted. ${ }^{140} 1 \mathrm{t}$ is notable that the judges in those cases sometimes shied away from equity talk and justified their supplementation on grounds of the law's spirit or suppression of mischief. As Virginia's Justice Carrington put it, the lodestar in applying statutes was not "strict rules of grammatical construction," but rather "the spirit, as well as the just exposition of the words of the law."141

136. 7 Va. (3 Call) 573, 578 (Va. Ct. App. 1790).

137. Id. at 579 (reporting Marshall's argument).

138. Id. at 579 (reporting Marshall's argument); see 2 The Papers of John Marshall: July 1788-December 1795, at 67-72 (Charles T. Cullen \& Herbert A. Johnson eds., 1977) (providing the historical context of the case).

139. Bracken, $7 \mathrm{Va}$. (3 Call) at 597. The court's precise reasoning was obscure even to the judges, who in a later case struggled to figure out exactly what they had decided earlier. See Bracken v. William \& Mary College, 5 Va. (1 Call) 161, 164 (1797).

140. See Bacon v. Masters, 2 Root 43, 44 (Conn. Super. Ct. 1793) (construing a remedial statute "liberally in advancement of the remedy and in suppression of the mischief'); Hancock v. Hovey, 1 N.C. 104, 105; 1 Tay. 60, 61 (1799) (asserting that statutory plain meaning can be sacrificed in order to cure the "mischief" at which the statute was aimed; here, "spirit" of law support the statute's extension); Brown, Campbell \& Co. v. Clary, 2 N.C. 125, 127-28; 1 Hayw. 107, 110-11 (1794) (creating new procedural form to effectuate spirit of 1789 law governing survival of claims); Lessee of Grant v. Eddy, 2 Yeates 148,150 (Pa. 1796) (employing a purposive approach to statutory interpretation); Watson \& Hartshorne v. Alexander, 1 Va. (1 Wash.) 340, 356 (1794) (following equity to extend statute).

141. Warder v. Arell, 2 Va. (2 Wash.) 282, 299 (1796) (Carrington, J.). 
Consistent with the caution suggested above, judicial exercise of a suppletive power was sometimes controversial. The Connecticut Superior Court struggled with this matter in Gustin v. Brattle. ${ }^{142}$ The administrator of an estate sued to enforce a bond created in 1758 and reaffirmed in 1764. The suit was outside the seventeen-year statutory limitations period unless the administrator could bring the claim within a statutory proviso allowing "persons over sea, or legally incapable to bring their actions" to sue within four years of their return or their becoming legally capable. The decedent had fled to Nova Scotia in $\mathbf{1 7 7 6}$ and died there; his estate was not admitted to probate until 1784. This situation was not within the foresight of the statute's drafters, ${ }^{143}$ but Chief Justice Law insisted that the proviso be construed "according to the true meaning and spirit of the statute" and to avoid "manifest injustice" to the estate. ${ }^{144}$ Judge Dyer agreed. A construction denying the estate its right to suit would "defeat the purpose of the proviso," which was to allow late-filed claims where the laches was not the fault of the plaintiff. ${ }^{145}$ "Though such an operation of the statute is not within its express terms, yet it is found to be within the reason; and whatever is within the reason of the statute, is within the statute." ${ }^{146}$ These judges were in the minority of the Superior Court bench; the majority limited the proviso strictly to its words. ${ }^{147}$ The Supreme Court of Errors, however, reversed the Superior Court, reportedly for the reasons given by Law and Dyer. ${ }^{148}$ Litigated on the eve of the Philadelphia Convention, the Brattle case is an excellent example of the cautious and often debated application of the equity of the statute idea. Although my limited sample of reported cases cannot establish how often courts invoked the equity of the statute on the eve of the Philadelphia Convention or during the ratification debates, the opinions in Brattle illustrate the perseverance of that judicial power.

\section{B. Ameliorative Powers}

I found a greater number of cases narrowing broad statutory language under courts' ameliorative powers. The animating philosophy undergirding most of these cases was libertarian. Thus, "laws should be so construed as to prevent an injury being done to the innocent," and there-

142. 1 Kirby 299 (Conn. Super. Ct. 1787).

143. The decedent had not exactly gone "over sea," for he had stayed within North America. (To get there, however, he could have traveled on the "sea.") Id. at 306 (Dyer, J., dissenting). More important, the proviso did not contemplate a situation where the creditor of a bond died and there was a long delay before probate. (The statute itself made allowance for the war for independence.) Id. at 305-08 (Dyer, J., dissenting).

144. Id. at 304-05 (Law, C.J., dissenting).

I45. Id. at 308 (Dyer, J., dissenting).

I46. Id. at 310 (Dyer, J., dissenting).

I47. Id. at 300-04 (per curiam).

148. See id. at 310 (noting that case was later reversed); Gates v. Brattle, 1 Root 187, 188 (Conn. Super. Ct. 1790) (describing the reasons for the supreme court's reversal in Brattle). 
fore according to principles of "reason and justice."149 Minor judicial surgery was the norm in cases such as Respublica $v$. Keppele, where the Pennsylvania Supreme Court refused to allow a parent to indenture his son to serve another family, notwithstanding the authorization of indentured servitude in an old law. ${ }^{150}$ ln Johnstons $v$. Meriwether, the Virginia Court of Appeals refused to apply statutes restricting bonds taken by sheriffs to cases where the giver of the bond was not in custody and therefore vulnerable to oppression by the local officials. ${ }^{151}$ Courts in these and similar cases had no problem announcing exceptions to old, broadly-phrased laws where application was not justified by the original statutory goal or by the common sense of the community.

ln some cases, judges openly rewrote laws that were, from their point of view, sloppily drafted. The North Carolina Court of Conference in Anderson's Administrators $v$. Anderson allowed a plaintiff to file an untimely declaration even though the statute said the trial court "shall dismiss." 152 This act of judicial lawmaking might have been justified by the procedural nature of the legislated rule. More typical was the Pennsylvania Supreme Court's approach to an inheritance law in Kerlin's Lessee v. Bull. ${ }^{153}$ An act of the assembly provided a rule for inheritance after the death of any father "and" mother. The court rewrote the law to apply to cases after the death of a father "or" mother. The court justified this construc-

149. Phile v. The Ship Anna, 1 U.S. (1 Dall.) 197, 200 (Pa. Ct. Comm. P1. 1787); see also id. at 200-01 (listing classic situations where ameliorative interpretation was thought necessary). Some of the suppletive power cases were animated by the same principle. See, e.g., Hall v. Hall, 1 Root 120, 120-21 (Conn. Super. Ct. 1789), where the court extended the words of a statute allowing a debtor to avoid arrest by tendering satisfaction of the debt, to include a situation where the debtor made the tender after the arrest. "[T] his statute which was made in favor of personal liberty, is to be construed liberally. . . There is not a single reason in favor of excusing the body, and taking estate, before a levy, that don't operate with equal force, for releasing the body, for estate after a levy upon it." Id. at 121-23. (The Supreme Court of Errors reversed, however, for practical reasons; it feared debtors would tender worthless properties to secure their release. Hall v. Hall, 1 Root 124, 124-25 (Conn. 1790)).

150. 2 U.S. (2 Dall.) 197 (Pa. 1793). Justice Bradford's opinion examined “principles of common law" and the "express words" of the statute, id. at 198; the limited purposes and "customs" of the statute of 1700 and similar laws in other states (namely, to allow adults to emigrate from Europe to the colonies), id. at 198-99; and general precepts of justice. "1 think it right to say, that no parent, under any circumstances, can make his child a servant, in the sense in which this boy is held as such." Id. at 199.

151. 7 Va. (3 Call) 523 (1790). Compare id. at 525 (reporting literalist argument of appellants), with id. at 527 (recording mischief-based argument of respondents, represented by John Marshall, who prevailed).

152. 1 N.C. 3, 3; 1 Mart. 19, 19 (Ct. Conf. 1789). Judge Williams "said he would consider the words in the act of assembly, 'shall dismiss,' as if they had said 'may dismiss." ld.

153. I U.S. (1 Dall.) 175 (Pa. 1786). 
tion on grounds of equity, other provisions in the statute assuming one parent had survived, and the "long accepted and received" practice. ${ }^{154}$

The few difficult cases involved relatively recent statutes whose literal application were felt to be severely inequitable. It is in these cases that the courts' ameliorative powers were most severely tested, or broadly asserted. One such case was Roach $v$. Commonwealth. ${ }^{155}$ Roach, a naval captain during the Revolution, sued for half-pay statutorily authorized for naval officers after their discharge. But in 1784 (three years after his discharge), he had accepted a commutation of his future half pay in return for five years of full-pay. A 1783 congressional resolve and its accompanying state statute said that "with respect to retiring officers, entitled to halfpay for life, the commutation, if accepted by them, shall be in lieu of whatever may be now due to them, since the time of their retiring from service." 156 Nonetheless, a jury awarded Roach more than three years of half-pay in addition to the five years of full pay he had already received, and a divided Pennsylvania Supreme Court affirmed. ${ }^{157}$ Chief Justice McKean's opinion started with a disclaimer that he preferred to err on the side of the individual, "because the error against the individual may be very distressing; whereas if against the Commonwealth, it will hardly be felt; and I know I must contribute my proportion of the money awarded." 158 He then interpreted the statute to affect only retiring officers of the army, and not naval officers like Roach. He compared the substantial provisions Congress made for retiring army officers with the few provisions for retiring naval officers. In language recalling Plowden, McKean concluded:

Could this have been the intention of the Legislature? I should think not, because of the great inequality it would create, not only between their officers in the Land-Service, and Sea-Service, contrary to their express declaration, but also between the latter themselves; for, by accepting the commutation, the one would lose more than another, in proportion to the times they were respectively discharged. This would be so unreasonable and unjust, that unless they had expressly and manifestly thus declared, I am inclined to entertain a contrary sentiment. ${ }^{159}$

To achieve a measure of rough equality, the chief justice narrowed the statutory exception to the half-pay obligation. This case assumes particular significance because it was decided by a court constituted under the Pennsylvania Constitution of I790, which followed the new U.S. Constitution in allocating powers among the branches of state government.

154. 1d. at 178-79; see also Lewis v. Maris, 1 U.S. (1 Dall.) 278, 288 (Pa. High Ct. Err. \& App. 1788) (featuring similar narrowing of an inheritance-evidence law, justified by the whole statute, the common law rule, and long-established practice).

155. 2 U.S. (2 Dall.) 206 (Pa. 1793).

156. Id. at 209 (emphasis omitted).

157. The court divided 2-2 on this issue. See id. at 211.

158. Id. at 208 (McKean, C.J.).

159. Id. at 210. 
One reason there were so many ameliorative power cases was the episodic popularity of the rule of lenity in state courts. ${ }^{160}$ An excellent example was Mongin v. Baker. ${ }^{161}$ ln 1782, South Carolina's legislature placed Mrs. Mongin's previous husband's estate on the "confiscation list," and she sued to preserve her common law dower rights. The state objected that the statute creating the list was inspired by the treason committed by the men named; both common law and English statutory experience presumed that dower rights were extinguished in forfeitures on grounds of treason. Notwithstanding this argument, the court unanimously read an exemption for dower rights into the law. "The maxim, that penal laws are to be construed strictly, is a wise one. The court is not bound to give, nor will they ever give such a harsh construction to the act, as to deprive a widow of a common law right, when the act itself is silent upon the subject." 162

Equally interesting was the New Jersey Supreme Court's decision in Smith $v$. Minor, a libel case involving alleged slurs that the plaintiff had committed fornication. ${ }^{163}$ The court held that the alleged statement did not constitute an assertion of fornication, concluding that the criminal law must be narrowly construed to apply only in cases where a child resulted. Such a limitation was not only consistent with the rule of lenity, but was needed to avoid indecent testimony in court. "Indecency is in some cases a legal reason for not sustaining a suit, and surely this consideration is entitled to some weight in ascertaining the true construction of a statute." 164

The flourishing of the rule of lenity sometimes came at the expense of the mischief rule, because criminal laws were aimed at extinguishing great public harms-a goal which narrow constructions would impede. Church v. Thomson ${ }^{165}$ was a lawsuit against a tanner who had worked "un-

160. See State v. Higgins, 1 N.C. 59, 72-73; 1 Mart. 62, 72 (1792) (narrow construction of law punishing servants for acting against their masters' interests); Respublica v. Richards, 2 U.S. (2 Dall.) 224, 227 (Pa. 1795) (McKean, C.J.) (asserting that rule of lenity and full faith and credit problems require dismissal of criminal prosecution of family for reclaiming their runaway slave); M'Mullen v. City Council of Charleston, 1 S.C.L. (1 Bay) 46 (1787) (stating that narrow reading of jurisdictional statute requires overturning conviction for selling alcohol without a license). The rule of lenity hardly meant that penal laws were always narrowed, though. See, e.g., Respublica v. Weidle, 2 U.S. (2 Dall.) 88, 90-91 (Pa. 1781) (involving seditious libel prosecution for drunken statements against the state); Commonwealth v. Posey, 8 Va. (4 Call) 109, 124 (1787) (reporting that divided court in a capital case followed established precedent denying benefit of clergy to a defendant convicted of burning down a dwelling).

161. 1 S.C.L. (1 Bay) 73 (1789).

162. Id. at 80 . Note that the confiscation list itself was a bill of attainder, arguably invalid under both the South Carolina and U.S. Constitutions. See id. at 76 n.(b).

163. 1 N.J.L. 16 (1790).

164. Id. at 23. Although the court construed the fornication law narrowly, it also upheld the libel action, on the ground that the claim could lay in spiritual defamation. Id. at 24.

165. 1 Kirby 98 (Conn. Super. Ct. 1786). 
sealed" leather into saddles and harnesses. The statute, however, only prohibited the use of unsealed leather "by any shoemaker," and the defendant argued that he was not within the statute. Two judges rejected that argument, because the "working of bad leather into saddles and other wares, is as expressly within the mischief the law intended to prevent, as the working of it into shoes; therefore within the spirit and meaning." 166 Judge Ellsworth and two others, however, ruled for the tanner, on the ground that the law, "being a penal statute, ought to be construed strictly, otherwise it might operate as a snare to mankind." 167 This decision illustrates the rule of lenity's power in the state courts-and perhaps of the ascendance of amelioration over supplementation as the preferred exercise of equitable interpretation.

\section{Voidance Power}

One reason the ameliorative power flourished was the ongoing influence of the common law, which most judges continued to treat as a baseline in statutory cases. ${ }^{168}$ This background norm also undergirded the voidance power asserted by Coke in Bonham's Case. The most famous prePhiladelphia Convention example of a narrowing construction of statutory law in light of fundamental (common) law was Rutgers $v$. Waddington. ${ }^{169}$ The case involved a patriot's property that had been seized by the British when they occupied New York City and that had been handed over to two loyalist merchants. After the war, a representative of the owner sued for rent and damages to her property through a writ of trespass; the merchants' defense was "military orders," whereby use of abandoned property was justifiable in time of war when authorized by the military commander in charge. Plaintiff negated the defense with a recent New York law disallowing the defense in cases arising out of the occupation-a law that defendants' counsel, Alexander Hamilton, denounced as contrary to the law of nations as incorporated in the New York Constitution and the state's common law. ${ }^{170}$ Interestingly, counsel for both plain-

166. Id. at 99 (Dyer \& Pitkin, JJ., dissenting).

167. Id. (Law, C.J., Sherman \& Ellsworth, J.). With due respect to ElIsworth and his colleagues, this strikes me as an odd deployment of the rule of lenity. The statute was badly drafted and not well thought-out, but the dissenters would seem correct in thinking that its remedy should have extended to saddles as well as shoes. There is no indication that the tanner would have gone to jail either. For a much more sensible exercise of the amelioration power by ElIsworth and his colleagues, see Hamlin v. Fitch, 1 Kirby 260 , 261-63 (Conn. Super. Ct. 1787), which exempted a loan from the state's usury law, on the ground that it was essentially a speculation rather than a true loan.

168. See, e.g., Respublica v. Doan, 1 U.S. (1 Dall,) 86, 91 (Pa. 1784) (reading common law rules into criminal attainder law); Strudwick v. Shaw, 2 N.C. 8, 14-I5; 1 Hayw. 5,11 (1791) (reading statute to incorporate common law rules).

169. Opinion of the New York Mayor's Court, Aug. 27, 1784, reprinted in 1 The Law Practice of Alexander Hamilton: Documents and Commentary 393-419 (Julius GoebeI, Jr. ed., 1964) [hereinafter Law Practicel.

170. The arguments in the case are thoroughly explored in 1 Law Practice, supra note 169, at 289-307 (providing Goebel's excellent commentary on the case). 
tiff and defendant agreed that the new statute should be "construed according to equity" and that the hermeneutical rule of Aristotle and Plowden should govern. The court agreed:

In order, says he, to form a right judgment whether a case be within the equity of a statute, it is a good way to suppose the law maker present, and that you asked him the question-did you intend to comprehend this case? Then you must give yourself such answer as you imagine, he being an upright and reasonable man, would have given. ${ }^{171}$

Counsel disagreed as to how equity should cut: Plaintiff relied on the remedial nature of the statute and its preservation of the common law trespass action, while defendant relied on the law of nations and the treaty of peace with Great Britain, which had a provision to the same effect. Chief Judge Duane of the New York City Mayor's Court took a broad view of the controversy, accepting both Hamilton's argument that the law of nations and the treaty of peace were relevant and plaintiff's view that the positive law adopted by the legislature should be applied. Paraphrasing Blackstone, the court insisted that judges were required to apply unreasonable statutory directives, so long as they were "clearly expressed, and the intention manifest," but when generally worded statutes yield unreasonable results in particular cases, courts are at liberty to "expound the statute by equity."172 The opinion recast the legal issue as whether the legislature clearly intended to revoke the law of nations and create a clash with the treaty of peace. "The repeal of the law of nations, or any interference with it, could not have been in contemplation, in our opinion, when the Legislature passed this statute; and we think ourselves bound to exempt that law from its operation ...."173 Freed from the operation of the statute, the court ruled that defendant was liable for rent but was excused from further liability. ${ }^{174}$

Rutgers $v$. Waddington was a sensation. A motion raised in the legislature to replace Duane was debated, and an open letter by nine interested New Yorkers charged him with confounding judicial and legislative powers by presuming to set aside a statute. ${ }^{175}$ Hamilton, John Jay, and other prominent New Yorkers defended the disposition. Duane defended him-

171. Rutgers, 1 Law Practice, supra note 169, at 396 (quoting Plowden). The court's opinion is a cornucopia of equity-in-statutory-construction quotations. See also id. at 414-15 (closely paraphrasing the maxim of Blackstone, Aristotle, et al., that "when a law is expressed in general words, and some collateral matter, which happens to arise from those general words is unreasonable" then judges ought to narrow the words according to "equity").

172. Id. at 415. Chief Judge Duane repeatedly emphasized both the supremacy of the legislature in making laws, id. at $415,416-17$, and the primacy of the judiciary in applying statutes to cases. ld. at 414,415 .

173. Id. at 417.

174. Ultimately, a judgment of 791 pounds was found for plaintiff, and the case was settled while on appeal. See 1 Law Practice, supra note 169, at 310-11.

175. See id. at 314. One signatory was Melancthon Smith, who was to become a prominent critic of the proposed Constitution. 
self privately in a letter to George Washington; the judge rejected the charge that his opinion had asserted a power to "control" the legislature and attached a copy of the opinion as proof. 1n a responsive letter, Washington said that "reason seems very much in favor of the opinion given by the Court, and my Judgment yields a hearty assent to it." 176 This exchange illustrates the shift in attitudes toward the judiciary that is the key point in the Wood thesis: The attitudes of the 1770 s, hostile to judicial technicalities and supportive of legislative solutions to popular problems, were being overtaken by a more mature attitude, whereby a broad rule of law enforceable by judges was needed to prevent legislative abuses.

ln Rutgers, Hamilton had argued that the New York law was void as contrary to the fundamental law of New York as well as the law of nations; one reading of Chief Judge Duane's opinion is that it was tantamount to setting aside a statute as inconsistent with higher law. However one reads the decision, Coke's idea that courts were obliged to set aside as void statutes contrary to higher law retained a significant and growing constituency in the United States, notwithstanding the disrespect Blackstone had given it. ${ }^{177}$ As early as 1782 , in Commonwealth $v$. Caton, the judges in Virginia reportedly agreed that "the court had power to declare any resolution or act of the legislature, or of either branch of it, to be unconstitutional and void," but were saved from applying the precept by construing-indeed, bending - their state constitution and applicable statute so to avoid such a conflict. ${ }^{178}$ The deliberation in Caton provides the basis for a less expansive reading of Rutgers: When a statute's general language runs up against higher law in the circumstances of a case, it is appropriate for judges to avoid the constitutional issue by narrow construction of the statute. James Iredell persuaded the North Carolina Supreme Court to adopt this principle in Bayard $v$. Singleton. ${ }^{79}$ Anticipating future defenses, Iredell maintained that judicial review was nothing more than ordinary judging - the judgment that an inferior law (the legislature's stat-

176. Id. at 314 (quoting letter of Apr. 10, 1785 from Washington to Duane).

177. My discussion of the American reception of Coke's idea does not assume that the judges accepted the natural law underpinning for Dr. Bonham's Case. For debate on this point, compare Suzanna Sherry, The Founders' Unwritten Constitution, 54 U. Chi. L. Rev. 1127, 1127-28 (1987) (stating that the Framers assumed natural law as a baseline), with Gary L. McDowell, Coke, Corwin and the Constitution: The "Higher Background" Reconsidered, 55 Rev. Pol. 393, 398-400 (1993) (arguing the contrary).

178. 8 Va. (4 Call) 5, 20 (1782) (Chancellor Blair et al.). The issue in the case was whether a statute seeming to require Senate and House approval for legislative pardons violated a constitutional provision seeming to allocate that power to the House alone. Both the constitution and the statute were oddly drafted, and the primary reported opinions went through many logical hoops to make sense of and eventually to reconcile the provisions. See id. at 9-13 (Wythe, J.); id. at 15-19 (Pendleton, J.). According to William Michael Treanor, The Case of the Prisoners and the Origins of Judicial Review, 143 U. Pa. L. Rev. 491, 529-32 (1994), the actual opinions in the case were more ambivalent as to the power of judicial review as a background consideration in the case.

179. 1 N.C. 42,45 ; 1 Mart. 48,52 (1789). 
ute) is inconsistent with a superior one (the state constitution). ${ }^{180}$ Without elaboration, the North Carolina court accepted this position in 1787 and refused to apply the unconstitutional statute. ${ }^{181}$

A case applying this kind of thinking to statutory interpretation was Ham v. M'Claws, decided just as the Constitution was ratified. ${ }^{182}$ Having been correctly informed that the law of South Carolina allowed foreigners to travel into the state with their slaves, Mrs. M'Claws, her children, and their slaves set sail from Honduras with the intent of settling in South Carolina. During their journey, South Carolina adopted a new statute making it illegal to bring slaves into the state, with an exception for U.S. citizens traveling through the state. When the M'Claws arrived, they were, unknowingly, in violation of the new law, and the state confiscated their slaves. Mrs. M'Claws objected to the "rigid construction" the state was giving the statute and sued to get the slaves back. The South Carolina Supreme Court unanimously agreed. "1t is clear, that statutes passed against the plain and obvious principles of common right, and common reason, are absolutely null and void, as far as they are calculated to operate against those principles." 183 Note the echo of both the dictum and the holding in Bonham's Case. Mrs. M'Claws' case presented a statute, "which, were the strict letter of it applied . . . would be evidently against common reason," but the court insisted it would not be so churlish as to impute to the legislature an intent to apply their law to a case such as hers. ${ }^{184}$ Accordingly, the court wrote:

We are, therefore, bound to give such a construction to the [act] as will be consistent with justice, and the dictates of natural reason, though contrary to the strict letter of the law; and this construction is, that the legislature never had it in their contemplation to make a forfeiture of the negroes in question . . . 185

Turner v. Turner's Executrix involved the interpretation of a 1758 Virginia statute voiding and refusing to recognize any gift of slaves unless recorded and otherwise supported by firm evidence specified in the

180. See Wood, Creation, supra note 14 , at 461-62.

181. Bayard, 1 N.C. at 45, 1 Mart. at 52. In addition to Rutgers, Caton, and Bayard, other pre-Philadelphia Convention state court decisions recognizing or exercising a judicial power to refuse to apply statutes inconsistent with state constitutions or fundamental law were Josiah Philips's Case (Va. 1778), discussed in 2 William W. Crossky, Politics and the Constitution in the History of the United States 944-48 (1953); Holmes v. Walton, (N.J. 1780), discussed in Austin Scott, Holmes $v$. Walton: The New Jersey Precedent, 4 Am. Hist. Rev. 456 (1899); Symsbury Case, 1 Kirby 444 (Conn. Super. Ct. 1785); Trevett v. Weeden (R.1. 1786), discussed infra at notes 190-194 and accompanying text. Early postConvention state court decisions to the same effect were Ham v. M'Clazus, 1 S.C.L. (1 Bay) 93 (1789), discussed infra at notes 182-185 and accompanying text; Gilman v. M'Clary (N.H. 1791), discussed in Lawrie, supra note 94, at 322-24; and Turner v. Turner's Executrix, 8 Va. (4 Call.) 234 (1792), discussed at infra notes 186-189 and accompanying text.

182. 1 S.C.L. (1 Bay) 93 (1789) (per curiam).

183. Id. at 98 (emphasis added).

184. Id. at 97 .

185. Id. 
act. ${ }^{186}$ Catharine and Benjamin Turner sued the executrix Clear Turner for two slaves they claimed had been verbally promised to them by the deceased, Sampson Turner. Plaintiffs won at trial, and on appeal the executrix invoked the 1758 statute. Plaintiffs responded with two arguments. First, the "mischiefs" set forth in the statutory preamble were secret sales seeking to defraud creditors and did not apply to the open exchange and possession of the slaves in question by Catharine and Benjamin. Second, a statute of 1787 made this interpretation explicit, by narrowing the 1758 statute to instances where possession of the slaves had been retained by the donor. ${ }^{187}$ President Pendleton's opinion for the Virginia Court of Appeals reversed. It summarily rejected the mischief argument for narrowing the statutory ambit but lingered on the second argument. If the 1787 statute did what plaintiffs claimed, it would have been unconstitutional as a usurpation of judicial authority to construe statutes and as an ex post facto law. ${ }^{188}$ In light of this constitutional problem, the court construed the 1787 law to have only a prospective operation. ${ }^{189}$

The most sensational voidance case arose out of raucous Rhode Island, which enacted a law requiring creditors to accept paper money at face value, and madating specially constituted tribunals for enforcement. In Trevett $v$. Weeden, ${ }^{190}$ a prosecution under the law in question, the defendant butcher followed Hamilton in claiming the law void as contrary to fundamental law. ${ }^{191}$ On the eve of the Philadelphia Convention, the Rhode Island Supreme Court dismissed the prosecution on jurisdictional grounds, but in oral opinions the next day most of the justices asserted the law was unconstitutional and void. ${ }^{192}$ (Rhode Island was the only state without a written constitution, so the judges were ruling the law inconsistent with fundamental law in the Coke sense.). Although the judgment was on jurisdictional grounds and the judges' substantive position sought to protect the most revered of the common law rights-the right to jury trials in criminal cases-the judges were admonished by an angry

186. 8 Va. (4 Call) 234 (1792).

187. See id. at 235.

188. Id. at 237.

189. Id.

190. The case is unreported, but the lawyer's account survives. James M. Varnum, The Case, Trevett v. Weeden: On Information and Complaint, for Refusing Paper Bills in Payment for Butcher's Meat, in Market, at Par with Specie (1787), discussed and quoted in Julius Goebel, Jr., Antecedents and Beginnings to 1801, at 137-41 (1971) (Oliver Wendell Holmes Devise History of the Supreme Court of the United States vol. I) [hereinafter Goebel, Antecedents].

191. Varnum argued that the law was void because it deprived defendants of jury trials and appeals. He invoked Bonham's Case, Bacon's Abridgment, and the collateral consequences rule in Blackstone (but not Blackstone's insistence that a clear statute could do any squalid thing). See id.

192. See id. at 140-41. Rhode Island's judges were for the most part not professional attorneys. Thus, it is particularly hard to draw broad conclusions from their decision or its reasoning. 
legislature and turned out of office in the next election (May 1787). ${ }^{193}$ Nonetheless, their action was widely appreciated. As one contemporary observer put it, the acts of the legislature were "liable to examination and scrutiny by the people, that is, by the Supreme Judiciary, their servants for this purpose; and those that militate with the fundamental laws, or impugn the principles of the constitution, are to be judicially set aside as void, and of no effect." 194

\section{I. The Judicial Power and Statutory Interpretation at the Philadelphia Convention, 1787}

No one has ever analyzed the debates at the Philadelphia Convention to determine whether there were consensus views about statutory interpretation. Unfortunately, there has been good reason for this scholarly gap: Records of the debates reveal few discussions of legal or statutory issues. On the other hand, some of the decisions they made reflected judgments about what the Article IIl "judicial Power" was expected to embrace in cases raising statutory issues. ${ }^{195}$ The deliberations at Philadelphia are consistent with Wood's account of the new ideology of law and the judiciary. The debates demonstrate that the Framers viewed an independent judiciary as an important check on legislative excess but probably did not approve of excessive judicial involvement in political matters. There is also some significance in what the delegates did not say. No one questioned the equitable constructions of statutes by English and state court judges, including those in the most noted (or notorious) cases, nor did anyone suggest that the common law, the law of nations, and the precepts of the Constitution itself would be anything but relevant to statutory interpretation by federal judges. At least some of the delegates, such as Hamilton, were lawyers famously associated with such ideas; other delegates, such as Oliver Ellsworth, Roger Sherman, George Wythe, and John Blair were judges who had put these ideas in to practice. Finally, no one suggested that equitable constructions according to the canons laid down in Blackstone and Bacon involved judicial lawmaking or even discretion. This Part considers the deliberations in some detail.

193. 1d. at 141.

194. Wood, Creation, supra note 14, at 456 (quoting Providence Gazette, May 12, 1787).

195. The main primary source for the Convention debates is the four-volume Max Farrand edition of The Records of the Federal Convention of 1787 (1986) [hereinafter Farrand, Records], which draws from various contemporary sources, especially Madison, who took copious notes at the Convention. Those sources are collected in Documents Illustrative of the Formation of the Union of the American States, H.R. Dac. No. 69-398, at 87-952 (Charles C. Tansill ed., 1st Sess. 1927) [hereinafter H.R. Doc. No. 69-398]. For secondary sources focusing on decisions about the "judicial Power," see Goebel, Antecedents, supra note 190, at 196-250; Haines, supra note 89, at 126-35; Edward S. Corwin, The Establishment of Judicial Review (pts. 1 \& 2), 9 Mich. L. Rev. 102, 283 (1910-11); Rakove, Origins of Judicial Review, supra note 88, at 1056-60. 
Early on, the delegates had a clear choice as to the structure of the national judicial power. C.C. Pinckney's plan built upon the Articles of Confederation, which vested special federal appellate jurisdiction in courts under the control of Congress. ${ }^{196}$ In contrast, Edmund Randolph's "Virginia Plan" (ghost-written by Madison ${ }^{197}$ ) propounded a supreme court presiding over inferior tribunals, with all courts consisting of judges chosen by the national legislature but serving for life ("during good behaviour") and with fixed compensation. Under this plan, federal courts would enjoy expansive jurisdiction, including over "questions which may involve the national peace and harmony." 198 This plan was a significant break with the Articles, for it would have institutionalized national organs restricting the states and, further, would have made those organs independent of the legislature. It dominated the Convention's focus on the judiciary and was consistently preferred by the delegates to mere tinkering with the Articles.

The Virginia Plan also proposed that the national legislature would have the power to negate state laws contravening the principles of the union and that a Council of Revision, consisting of the chief executive and a "convenient number" of judges could block these negatives as well as bills passed by the national legislature (subject to a supermajority override by the legislature) ${ }^{199}$ Reflecting Madison's fears of legislative mobs, the object of the Council of Revision was to check legislative encroachment on judicial prerogatives and legal values. On June 4, 1787, the Convention first debated the proposal. Elbridge Gerry objected that a preenactment check was unnecessary for judges, "as they will have a sufficient check agst. encroachments on their own department by their exposition of the laws, which involved a power of deciding on their Constitutionality. . . . It was quite foreign from the nature of ye. office to make them judges of the policy of public measures." 200 Rufus King agreed and added that "Judges ought to be able to expound the law as it should come before them, free from the bias of having participated in its formation."201 John Dickinson explained why the executive might participate in a veto but judges should not: "the Judges must interpret the Laws they

196. See Articles of Confederation art. 1X.

197. See Rakove, Original Meanings, supra note 14, at 59.

198. 1 Farrand, Records, supra note 195, at 21-22.

199. See id. at 21 (Resolutions 6 and 8, respectively). On the Convention's consideration of the national legislature's power to negate state laws, see Charles $F$. Hobson, The Negative on State Laws: James Madison, the Constitution, and the Crisis of Republican Government, 36 Wm. \& Mary Q., 3d Ser., 219 (1979). On the Convention's consideration of the Council, see Charles Warren, The Making of the Constitution 332-38 (1928); Rakove, Origins of Judicial Review, supra note 88, at 1056-60; James T. Berry 1II, Comment, The Council of Revision and the Limits of Judicial Power, 56 U. Chi. L. Rev. 235, 248-57 (1989).

200. 1 Farrand, Records, supra note 195, at 97-98.

201. 1d. at 98; see id. at 109 (reporting longer version of King's comment). 
ought not to be legislators," while the executive's role is "ministerial."202 The delegates voted, eight states to two, to adopt Gerry's motion that the veto should be only by the executive and could be overridden by twothirds of the legislature. ${ }^{203}$

At James Wilson's request, the delegates agreed to reconsider and did so on June 6.204 Expanding the case for a Council of Revision, Madison argued that judicial participation would provide needed backbone for executives fearful of the political consequences of a veto, would prevent the executive from unwise vetoes, and would defend the independence of the judicial branch. ${ }^{205}$ Madison conceded that Gerry's bias objection had weight but responded that "a small proportion of the laws coming in question before a Judge wd. be such wherein he had been consulted; that a small part of this proportion wd. be so ambiguous as to leave room for his prepossessions." ${ }^{206}$ Nonetheless, the proposal again went down, this time eight states to three. ${ }^{207}$

On June 4, the delegates voted for the Virginia Plan's judiciary resolution, thereby approving the establishment of a national judiciary headed by a supreme court with review authority over state as well as federal courts. ${ }^{208}$ The appointment process for federal judges was left undecided, ${ }^{209}$ but the judges were to serve for life ("during good behaviour") and without diminution of salary. The Virginia Plan was amended to leave the establishment of inferior federal courts up to legislative "appointment." 210 At this point in the Convention, states-rights delegates had become alarmed about the accumulating national power-hence the jurisdiction of federal tribunals was left unresolved as well.

On June 8, the Committee of the Whole debated Pinckney and Madison's proposal that the national legislature be given a negative on all state laws that the members of the national legislatures "shall judge to be improper." 211 This was a greater power than the negative propounded on May 29 by Randolph for laws the legislature thought unconstitutional, which the delegates had accepted on May 31.212 Because delegates be-

202. Id. at 108-09; see id. at 110 (situating Dickinson's remark as a response to Madison's argument that the executive and judicial officials would pool their wisdom in collaborating in a veto).

203. See id. at 104 .

204. Id. at $138-40$.

205. Id. at $138-39$.

206. Id. at 138. Against this small problem, Madison weighed the great good that would come from "the perspicuity, the conciseness, and the systematic character wch. the Code of laws wd. receive from the Judiciary talents." 1d. at 139.

207. Id. at 140 .

208. Id. at 94 .

209. Wilson favored appointment by the executive, id. at 119,126, 127, Madison by the upper chamber of the legislature, id. at 120, and Hamilton by the executive subject to upper-chamber ratification, id. at 128 .

210. See id. at $118,127$.

211. Id. at $164-65$.

212. Id. at 162. 
lieved such a broad negative was unworkable and would "enslave the states," ${ }^{119}$ as Gerry put it, Pickney and Madison's proposal was rejected, ${ }^{214}$ and for the next week the delegates touched on state autonomy concerns constantly as they debated further features of the Virginia Plan. On June 12, the Committee deleted several of the proposed heads of federal jurisdiction (including diversity cases), and the next day Randolph presented a redrafted clause extending jurisdiction only to "cases which respect the collection of the national revenue, impeachments of any national officers, and questions which involve the national peace and harmony."215 The committee unanimously agreed to this proposal. ${ }^{216}$

William Paterson on June 15 presented the New Jersey Plan, embodying proposed compromises between the concerns of big and small states, and between the Articles of Confederation and the nationalistic Virginia Plan. The new plan would have created a supreme judicial tribunal with jurisdiction only in cases involving prizes, ambassadors, piracies and felonies on the high seas, foreign interests, treaty interpretation, and statutes for the regulation of trade and collection of revenue. ${ }^{217}$ Most important, the New Jersey Plan provided that all national statutes and treaties "shall be the supreme law of the respective States ... and that the Judiciary of the several States shall be bound thereby in their decisions, any thing in the respective laws of the 1ndividual States to the contrary notwithstanding." ${ }^{218}$ Although the Convention returned to the Virginia Plan after extensive debate about this alternative, the New Jersey Plan was important in introducing a supremacy clause and in stimulating serious efforts to placate the small states.

The main concession to small states was the great compromise adopted on July 16,1787 , dividing the national legislature into a chamber where each state got the same number of votes and another chamber divided by population. More important for our inquiry is the fate of the legislative negative of state laws. To save the negative, Randolph had developed a proposal whereby the states would have a right of appeal to the national judiciary, which could abrogate the legislative veto. Also under Randolph's proposal, any person "conceiving himself injured or oppressed by the partiality or injustice of a law of any particular State may resort to the National Judiciary, who may adjudge such law to be void, if

213. Id. at 165; see id. at 164-67 (recording opposition to the Madison-Pickney proposal).

214. Id. at 168.

215. ld. at 223-24.

216. Id. at 238.

217. See H.R. Doc. No. 69-398, supra note 195, at 968-69 (reproducing the New Jersey Plan). The supreme judicial tribunal would apparently have had original jurisdiction in some of these cases. Jurisdiction for prosecutions pursuant to federal criminal laws would have been left to the "Common Law Judiciaries of the State" where the offense was committed. ld. at 967 .

218. Id. at 969 (Resolve No. 6). 
found contrary to the principles of equity and justice."219 Randolph's idea was never presented to the Convention, which instead considered the Virginia Plan's proposal authorizing the legislature to negate state laws it considered unconstitutional. Gouverneur Morris believed the negative to be duplicative: "A law that ought to be negativized will be set aside in the Judiciary department, and if that security should fall, may be replaced by a National law. ${ }^{220}$ The Convention voted seven states to three to drop the negative-of-state-laws provision ${ }^{221}$ but then unanimously adopted a supremacy clause almost identical to that in the New Jersey Plan. ${ }^{222}$ Randolph and Madison's notion that obstreperous state laws should be controlled by a legislative veto lost out to Paterson and Morris' idea that state and federal judges should be the monitors of such mischief.

Because it reconfigured the proposed national legislature, the great compromise of July 16,1787 required a fresh look at the Convention's earlier decision to vest judicial appointments in the upper chamber of the Congress. The delegates wrangled over this issue and the jurisdiction issue episodically throughout July. In the meantime, they readily agreed to life tenure during good behavior ${ }^{223}$ and for a bar to salary cuts but not salary increases. ${ }^{224}$ On July 21 , Wilson renewed the proposal for judicial participation in the executive veto, and the ensuing debate was the most elaborately reported discussion of this oft-visited topic. Wilson conceded the power of the argument that post-enactment judicial review would protect against constitutional infringements, but insisted that the power of the judges did not go far enough. "Laws may be unjust, may be unwise, may be dangerous, may be destructive; and yet not be so unconstitutional as to justify the Judges in refusing to give them effect." 225 Their participation in the veto would help protect against such unwise laws and "the improper views of the Legislature." ${ }^{226}$ Nathaniel Gorham responded that "[a]s Judges they are not to be presumed to possess any peculiar knowl-

219. 3 Farrand, Records, supra note 195, at 55-56. Randolph shared this proposal with Madison on July 10, but it was not formally presented to tbe Convention.

220. 2 Farrand, Records, supra note 195, at 27, 28. Roger Sherman urged that state courts would themselves invalidate the law, but Madison worried that state judiciaries would be too much under the thumb of their legislatures to stand firm against such laws on a consistent basis. ld. at 27 .

221. Id. at 28-29.

222. Id. at 21-22.

223. Id. at 38 .

224. Id. at $44-45$.

225. Id. at 73 .

226. Id. Madison spoke to similar effect. Judges would bring insights about legal "consistency" and "technical propriety in the laws, qualities peculiarly necessary; \& yet shamefully wanting in our republican Codes. It would moreover be useful to the Community at large as an additional check agst. a pursuit of those unwise \& unjust measures which constituted so great a portion of our calamities." Id. at 74. George Mason agreed that judicial review would not check "unjust and pernicious laws." Thus, Mason believed that: 
edge of the mere policy of public measures" and that "Judges ought to carry into the exposition of the laws no prepossessions with regard to them." 227 Gerry argued that the proposal "was a combining \& mixing together the Legislative \& the other departments. . . . It was making Statesmen of the Judges . . . It was making the Expositors of the Laws, the Legislators which ought never to be done."228 Luther Martin added a new, and highly astute, objection: "It is necessary that the Supreme Judiciary should have the confidence of the people. This will soon be lost, if they are employed in the task of remonstrating agst. popular measures of the Legislature."229 Wilson's motion lost, three states in favor, four opposed, two divided. ${ }^{230}$

After the July 1787 debates and decisions, the Convention authorized a Committee of Detail to draft a comprehensive document embodying the resolutions agreed to. The Committee reported on August 6. The judiciary article created a federal supreme court, authorized Congress to appoint inferior tribunals, vested judicial appointments in the Senate, gave judges their positions during good behavior and without salary diminution, and (in a dramatic move) authorized federal jurisdiction over cases arising under federal laws, diversity cases, disputes between states, admiralty cases, and other matters now fixed in Article III. ${ }^{231}$ The Convention deliberated on this draft throughout August. On August 15, it defeated Madison's and Wilson's motion to give the Supreme Court an independent and concurrent veto of legislative enactments. ${ }^{232}$ On August 23, the Convention approved the Supremacy Clause as it now appears in Article VI. ${ }^{233}$ The Convention tinkered with the judiciary article on August 27, but defeated proposals to make the judiciary more dependent on the legislative branch and expanded upon the jurisdiction and

with regard to every law however unjust oppressive or pernicious, which did not come plainly under this description [unconstitutional], they would be under the necessity as Judges to give it a free course. He wished the further use to be made of the Judges, of giving aid in preventing every improper law.

ld. at 78; cf. Alfred B. Street, The Council of Revision of the State of New York 201-402 (1859) (detailing selection of Council vetoes); Berry, supra note 199, at 245-46 \& n.45 (documenting that more than half of the Council's vetoes were for policy reasons and onethird for constitutional or partly constitutional reasons).

227. 2 Farrand, Records, supra note 195, at 73, 79.

228. ld. at 75. Caleb Strong agreed "that the power of making ought to be kept distinct from that of expounding, the laws. No maxim was better established. The Judges in exercising the function of expositors might be influenced by the part they had taken, in fraining the laws." 1d. Morris dismissed this argument: Judges in England had participated in the making of laws for generations, yet that had not corrupted their ability to judge. Id. at $75-76$.

229. Id. at $76-77$.

230 . Id. at 80 .

231. Id. at $186-87$ (setting forth Article XI of the Committee's draft).

232. The same arguments were made pro and con, see id. at 298 , and the motion lost eight states to three. Id. at 294-95.

233. Id. at 381-82, 389. Pinckney renewed the proposal of congressional negative on state laws, but this was narrowly defeated, five states to six. Id. at 390-91. 
authority of the judicial power. ${ }^{234}$ After minor redrafting by the Committee of Style and further Convention tinkering, Articles 111 and VI and the remainder of the proposed Constitution were approved, engrossed, and signed on September 17, 1787.

Without taking any position as to how to value any consensus at the Philadelphia Convention, 1 draw the following preliminary conclusions from the foregoing account. For starters, the delegates deliberately and repeatedly chose to depart from the scheme of the Articles of Confederation by creating an independent national judiciary as a serious third branch of government. Although the delegates never voted to vest the judiciary with authority to invalidate state or federal laws inconsistent with the Constitution, the Supremacy Clause in Article VI made it most likely that federal as well as state courts would be required to follow federal statutes, treaties, and constitutional provisions instead of contrary state laws, and likely to follow the Constitution over contrary federal laws. The Supremacy Clause and the federal question heads of jurisdiction in Article IIl suggest that federal as well as state judges were charged with responsibility for interpreting federal statutes and treaties; the Supreme Court would have the final (judicial) word as to such interpretation. ${ }^{235}$ The voidance power so controversial in the United Kingdom was the law of the land in the United States. Historians Sylvia Snowiss and Gordon Wood suggest that a necessary corollary of this decision was the Framers' vesting the Supreme Court with the authority to develop Coke's inchoate idea of fundamental law in the ordinary process of constitutional and statutory interpretation. ${ }^{236}$ This corollary was not completely accepted by skeptics such as Jefferson, ${ }^{237}$ but it was a decision made at Philadelphia and implemented by the Supreme Court.

It is perilous to argue, from the sparse accounts we have, that there was any further specific consensus about the method federal judges were supposed to use in construing statutes. There was no formal vote on a matter relating to statutory interpretation, and the evidence as to assumptions about such interpretation is thinner than the evidence as to judicial review. The strongest hypothesis is that the delegates both assumed and accepted the traditional rules and canons of statutory interpretation and did not see the "judicial Power" to interpret statutes as deviating from the general methodology laid out in the traditional cases and treatises that

234. See Goebel, Antecedents, supra note 190, at 240-44 (summarizing the complicated array of proposals and votes).

235. That implication was an explicit premise of Wilson's and Madison's defense of the Council of Revision and of Gerry's and Strong's criticism of it. See supra notes 199-207 and accompanying text. No one at the Convention questioned this proposition.

236. See Sylvia Snowiss, Judicial Review and the Law of the Constitution 64-65 (1990); Wood, Origins, supra note 75, at 801-02.

237. See Wood, Origins, supra note 75, at 802-03. Jefferson, however, did believe that judicial review of unconstitutional state laws was much better than a legislative negative on state law. See Letter from Jefferson to Madison, June 20, 1787, reprinted in 10 The Papers of James Madison 64 (Robert Rutland et al. eds., 1975). 
were considered authoritative by the state judiciaries and that would have been known by most of the thirty-four delegates who had legal training. These included most of the major speakers at the Convention: Madison, Hamilton, Wilson, Morris, Randolph, Dickinson, Ellsworth, Paterson, Sherman, Wythe, Blair, King, Rutledge, both Pinckneys, and Martin. ${ }^{238}$ Most of these relatively learned lawyers would have been familiar with Coke's Institutes, Bacon's Abridgment and its list of interpretive canons, Blackstone's Commentaries, Plowden's comment on Eyston v. Studd, the mischief rule of Heydon's Case, the holding and dictum of Bonham's Case, and Rutgers and Trevett. 1 should not say that all the delegates drew the same methodological conclusions from these sources. The power of judicial review, expressed through dicta in Bomham's Case and Caton and practiced in Bayard and Trevett, would have been the most controversial proposition, but there is reason to believe that it was accepted by most of the delegates. ${ }^{239}$ In that event, the less ambitious power of construing statutes to avoid clashes with fundamental law (classically developed in Rutgers and clumsily deployed in Trevett) was most likely to have been acceptable as well.

A more speculative hypothesis is that the delegates expected Article III judges to refuse to enforce federal as well as state laws (or, as in Bonham's Case, read them narrowly) because they are unconstitutional or (possibly) inconsistent with fundamental law, but not to refuse enforcement (or to read narrowly) laws because they are unwise or reflect poor policy judgments. Counting in favor of this hypothesis is that it maps onto Bacon's maxim that "where the Meaning is plain no Consequences are to be regarded in the Construction; for this would be assuming a legislative authority" 240 and Blackstone's insistence that judges must enforce a law that is unreasonable on its face even though they might narrow general statutory phrasing to avoid unreasonable applications. ${ }^{241}$ Additionally, the hypothesis was the basis for one argument Wilson and Madison made in favor of the Council of Revision (it was needed because judges could not strike down unwise but constitutional laws), as well as Gerry's main argument against it (judges ought make legal but not policy judgments)..$^{242}$ In other words, both the leading proponents and a lead-

238. See generally Forrest McDonald, We the People: The Economic Origins of the Constitution 86-87 (1958) (listing delegates with legal training).

239. Tbere has been some dispute as to the Convention's stance toward judicial review. Compare Charles A. Beard, The Supreme Court and the Constitution 64-65 (1938) (providing a head-count of the delegates suggesting that the judicial review power was accepted by an absolute majority), with Haines, supra note 89, at 132-35 (arguing that Beard's evidence is inconclusive). Commentators now treat judicial review as a premise generally accepted at Philadelphia. See, Goebel, Antecedents, supra note 190, at 237-39.

240. Bacon, Abridgment, supra note 38 , at 652.

241. See Blackstone, supra note 39 , at $* 91$.

242. See supra notes 199-207 and accompanying text; see also Raoul Berger, Government by Judiciary: The Transformation of the Fourteenth Amendment 300-06 (1977) (relying on the debates over the Council to argue against "judicial legislation"). 
ing opponent of the Council of Revision argued that it was needed-or was dangerous-because judges' ordinary role in statutory interpretation did not question the wisdom of the overall policy choices the legislature had made. This matter has been obscured by the fact that this assumption was not the main argument for the proposal, that many other reasons were adduced against the proposal, ${ }^{243}$ and that most delegates said nothing relevant to the hypothesis.

Although Manning nervously distances himself from "relying" on the Framers' debates at Philadelphia, ${ }^{244}$ he and I share common ground in accepting this last point as a working hypothesis. Where we differ is in the further conclusions that can be drawn from the Constitution. Manning maintains that equitable interpretation is inconsistent with the Framers' decisions to make federal judges independent of the political process and to separate judicial (Article III) powers from legislative (Article I) powers. ${ }^{245}$ His evidence is persuasive support for the idea that judicial independence was expected to check legislative abuses and ensure the rule of law, but it fails to justify his further conclusion that those premises are hostile to equitable interpretation. It is noteworthy that Manning was unable to find a single Framer or a single judge of the period who expressed the link he insists upon. In an article brimming with quotations, unearthed in what must have been a massive research program, it is amazing that he was not able to come up with even one quotation supporting the central claim of his paper. The reason is that lawyers of the period, including important Framers, did not see the matter his way.

Most American lawyers of the 1780s did not view the role of equity in statutory interpretation as judicial legislation, as Manning seems to do. Blackstone and Bacon taught the colonists and the new Americans that equitable constructions were governed by canons and rules; indeed, their canons insisted that statutes be construed equitably, pursuant to a proper

243. See Rakove, Origins of Judicial Review, supra note 88, at 1058 (listing six arguments against the Council: (1) judges' power to expound the laws (including their constitutionality) provided them with sufficient check against bad laws; (2) prior involvement in legislation weakens the capacity of judges to decide cases later on; (3) judges have no special knowledge of policy matters; (4) the Council improperly mixed different powers; (5) judicial participation would weaken the accountability of the executive for vetoing measures; and (6) the security of popular measures belongs with the political branches.).

244. See Manning, Equity of the Statute, supra note 8, at 59-60 n.237 (presuming that the "secret deliberations" at Philadelphia can provide no authoritative basis for an "understanding of the ratifiers who ultimately gave the document life," but that they might be relevant when "they reflect a shared expectation" about the words of the Constitution); cf. City of Boerne v. Flores, 521 U.S. 507, 537-44 (1997) (Scalia, J., concurring in part) (refusing to join majority opinion's discussion of drafting history of the Fourteenth Amendment as authority for construing its text).

245. See Manning, Equity of the Statute, supra note 8 , at 57-70, for a most illuminating discussion of evolving American thinking about judicial independence in the $1780 \mathrm{~s}$, and a more speculative application of those thoughts to equitable interpretation. 
rule of law. Most important, the leading historians-especially Wood and Rakove-insist that the move toward judicial independence that Manning wonderfully documents was meant to check legislative interference with fundamental law and legal rights, such as those embodied in the Constitution, and soon the Bill of Rights (ratified by 1791). ${ }^{246}$ Thus, judicial independence was necessarily linked to what I call the voidance power, including the power to narrow constitutionally troublesome statutes, and is arguably linked also to what I call the ameliorative power. The willingness of the judges, such as those in Rutgers $v$. Waddington, to confine broad statutory language by reference to the larger tapestry of law-the common law and the law of nations as well as the Constitution-was considered part of the judicial power's contribution to the rule of law and its security for the average citizen. I agree with Manning, however, insofar as he is arguing that the Framers' understanding of separation of powers cautions against judges' naked substitution of their own policy preferences for those of the legislature. And Manning makes a better case against the suppletive power (the equity of the statute, properly understood) than against the ameliorative power (which he treats as part of the equity of the statute doctrine).

At first blush much more speculative but ultimately more interesting is Manning's argument that the Framers' decision in Article I, Section 7 to require bicameral approval and presidential presentment for legislation was a death blow to equitable interpretation. He asserts that these procedures were meant to protect political minorities, which could be undone by judicial "authority to add to or subtract from the results of that process." ${ }^{247}$ There are many problems with this argument. Not a single Framer or contemporary observer made the connection between Article I, Section 7 and the ambit of Article III's "judicial Power," surely for the same reasons adduced in the prior paragraph. ${ }^{248}$ Lawyers of the period would not have considered equitable constructions, along Baconian or Blackstonian lines, to have been judicial modifications of statutes that went through the bicameral and presentment process. The voidance and ameliorative powers were conceived by Framers-such as Hamilton-as further protections for minorities. ${ }^{249}$

Notwithstanding all these historical difficulties, Manning makes a great point in suggesting that the effect of Article I, Section 7 was to re-

246. See Rakove, Origins of Judicial Review, supra note 88, at 1060-64; Wood, Origins, supra note 75 , at 803 .

247. Manning, Equity of the Statute, supra note 8, at 57; see id. at 70-78.

248. The failure of anyone to notice a connection that Manning thinks so obvious is the dog that did not bark. One would expect someone to make the connection, and the failure of anyone to do so is evidence that the connection is invalid. See Chisom v. Roemer, 501 U.S. 380, 396 (1991); but cf. id. at 405 (Scalia, J., dissenting) (growling vigorously about dog-that-did-not-bark arguments).

249. There are more problems: An interesting one is that Manning's Article I, Section 7 argument is a stronger objection to "lawmaking" by modern administrative agencies than to narrowing constructions by judges. 
quire more compromises as a price of legislation, and that judicial constructions undermining such compromises might be in tension with that legislative structure. ${ }^{250}$ Unless justified by (for example) changed circumstances, suppletive constructions run the biggest risk of undermining legislative compromises, and the Article 1, Section 7 argument works best as a criticism of particular applications of the pure equity of the statute concept. Admittedly, this is a completely abstract point, for no judge of the period, no Framer, and no historian has ever noted this connection, which I find plausible in Manning's argument.

\section{Statutory 1nterpretation and the Ratifying Debates, 1787-89}

In political theory, the most distinctive feature of the proposed Constitution is that it contemplated ratification by a popular process-not by state legislatures, but by specially assembled conventions of delegates elected by the (male, white, property-holding) people and reflecting popular input. ${ }^{251}$ For this reason, any consensus among the ratifiers regarding the judicial power would carry particular normative weight. Unlike the discussions at Philadelphia, the war of the pamphlets between Federalist and Anti-Federalist authors and the debates at some of the ratifying conventions specifically focused on statutory as well as constitutional interpretation. ${ }^{252}$ The ratifying debates support, perhaps strongly, the proposition that federal courts would have ameliorative and voidance powers and possibly suppletive powers as well. ${ }^{253}$

Manning's argument that the debates are inconclusive is based on his deft but unsuccessful wedding of Anti-Federalist charges that equitable interpretation would allow federal judges discretion to invade per-

250. See Manning, Equity of the Statute, supra note 8 , at 71 ; see generally William N. Eskridge, Jr. \& John Ferejohn, The Article 1, Section 7 Game, 80 Geo. L.J. 523, 528-56 (1992) (critiquing narrow formalist understandings of bicameralism and presentment and offering alternate dynamic model).

251. See Rakove, Original Meanings, supra note 14, at 96-101.

252. The best treatments of statutory interpretation as an issue with the ratification debates are Jonathon T. Molot, The Judicial Perspective in the Administrative State: Reconciling Modern Doctrines of Deference with the Judiciary's Structural Role, 53 Stan. L. Rev. 1, 20-41 (2000); Powell, supra note 42, at 904-13. Excellent historiographical accounts of the ratification debates include Goebel, Antecedents, supra note 190, at 292-412; Rakove, Original Meanings, supra note 14, at 94-130 (providing a chronological account) \& passim (exploring the political and conceptual issues at stake).

253. Almost all the primary documents I shall mention are collected in The Debate on the Constitution: Federalist and Antifederalist Speeches, Articles, and Letters During the Struggle over Ratification (Bernard Bailyn ed., 1993) [hereinafter Bailyn's Debate], and most are also in The Documentary History of the Ratification of the Constitution (John P. Kaminski \& Gaspare J. Saladino eds., 1983) [hereinafter Documentary History]. Useful material can also be found in 2 Jonathan Elliot, The Debates in the Several State Conventions on the Adoption of the Federal Constitution, as Recommended by the General Convention at Philadelphia, in 1787, at 257-58 (Jonathan Elliot ed., 2d ed., Philadelphia, J.B. Lippincott Co., 1888) [hereinafter Elliot's Debates], and The Complete Anti-Federalist (Herbert J. Storing ed., 1981). 
sonal and states' rights, with what he views as Federalist claims that Article III judges would not exercise discretion. ${ }^{254}$ I think he misreads the snippets of evidence that he cites. Because the misreading becomes clearer in the context of the entire debate, we need to work through the ratifying process as a whole. The debates support the thesis that the judicial power entailed ameliorative and voidance authorities for federal judges and are wary or critical as to suppletive authority.

It is too quick to say, as some commentators have, that the judicial power was not a significant focus of contention in the ratification debates. ${ }^{255}$ The central themes of the critics were that the Constitution sufficiently protected neither the liberties of citizens nor the autonomy of the states, and that from the very beginning Article III was a recurring example of those defects. James Wilson's speech of October 6, 1787, was the first major public defense of the Constitution against early attacks, and the most elaborate reply to his speech, by the Centinel, emphasized Article III. ${ }^{256}$ The Centinel's main objections were that the Constitution had no bill of rights to protect citizens and that it was designed to eliminate state autonomy. As to the latter charge, Congress's broad Article I authority could be expected to eclipse state legislatures, while the judiciary's broad jurisdiction under Article III could be expected to eclipse state courts. ${ }^{257}$ Once the federal jurisdiction eradicated that of the states, so then would jury trials cease to exist in civil cases, as they were abolished by the Constitution. ${ }^{258}$ These innovations would, he said, favor the rich and enslave the poor, unsettle vested rights and local practices, and destroy the states. ${ }^{259}$

254. Manning, Equity of the Statute, supra note 8, at 79-85. As before, Manning's account is beclouded with historicist complexities. For example, he uncritically treats judicial "discretion" as something of which the Framers disapproved between 1787 and 1789. During the debates, Hamilton was not bothered in the least by "diversities in the opinions" of judges, see The Federalist No. 22, at 150 (Alexander Hamilton) (Clinton Rossiter ed., 1961) (arguing for a supreme tribunal to settle such inevitable diversities), or by "judicial discretion," see The Federalist No. 78, at 468 (Alexander Hamilton) (Clinton Rossiter ed., 1961). The proper distinction is this one: "Legal discretion is limited. . . Political discretion has a far wider range." United States v. The William, 28 F. Cas. 614, 620 (D. Mass. 1808) (No. 16,700).

255. E.g., Larry D. Kramer, But When Exactly Was Judicially-Enforced Federalism "Born" in the First Place?, 22 Harv. J.L. \& Pub. Pol'y 123, 124-25 (1998) (claiming that the Framers hardly discussed judicial review).

256. The Centinel II, Freeman's J. (Phil.) Oct. 24, 1787, reprinted in 1 Bailyn's Debate, supra note 253, at 77-91 [hereinafter Centinel 1I] (responding to Jaines Wilson, Speech at Public Meeting (Oct. 6, 1787), reprinted in 1 Bailyn's Debate, supra note 253, at $63,69)$.

257. Id. at $82-83$.

258. 1d. at 83-84. Of course that was wrong; jury trials in civil cases were neither assured (as they were for criminal cases) nor abolished by Article I11. But see Cincinnatus II, N.Y. Journal, Nov. 8, 1787, 14 Documentary History, supra note 253, at 11-13 (invoking inclusio unius maxim to show that the assurance of juries in criminal cases suggested they were taken away in civil cases).

259. See Centinel 11, supra note 256 , at $84-85$. 
The Centinel's reply was representative of the Anti-Federalist speeches, letters, and pamphlets in giving some emphasis to the judiciary in developing arguments against the Constitution. Specifically, Anti-Federalist writers of all sorts objected that Article III (1) failed to preserve jury trial rights in civil cases (as it did in criminal cases) and therefore put civil litigants at peril; (2) gave the Supreme Court appellate review over matters of "law and fact," and therefore allowed federal judges to overturn jury determinations; (3) wantonly combined law and equity jurisdiction in the same judges, thereby giving them unlimited discretion; (4) supplanted the common law with national statutes and treaties that would be liberally interpreted; (5) vested federal jurisdiction in (diversity) cases that were better left in state courts and that would favor foreign litigants; and (6) made the states amenable to suit in federal court and subjected state courts to marginality given expansive federal jurisdiction the courts would apply liberally. ${ }^{260}$

Wilson's speech had touched on the jury trial objection, but by the end of the year the Federalists were discussing the judicial power a great deal. The most clever Federalists started with the positive case for Article III, namely the country's need for a national judiciary. As Hamilton (writing as Publius) put it, "laws are a dead letter without courts to expound and define their true meaning and operation," and treaties as well as laws must have a uniform construction. ${ }^{261}$ A problem with the Articles of Confederation was their inability to secure such uniformity of interpretation, or even impartial justice in cases such as those involving foreigners or citizens of different states; problems with the Constitution paled in comparison with the status quo. Consistent with the implications of Hamilton's response, Madison later added that Anti-Federalist charges of ambiguity in the Constitution were overstated. Even Holy Scripture contained ambiguities. ${ }^{262}$ In an observation consistent with the Federalist position throughout the debates, Madison added this generalization about statutory interpretation in 7he Federalist 37: "All new laws, though

260. For early criticism along these lines, see Centinel 1, Independent Gazeteer, Oct. 5, 1787, reprinted in 1 Bailyn's Debate, supra note 253, at 52-62 (objections (1), (2), (5), (6)); Reply to Wilson's speech: A Democratic Federalist, Penn. Herald, Oct. 17, 1787, reprinted in 1 Bailyn's Debate, supra note 253, at 70-76 (objections (1)-(3), (5), (6)); Speech of a Citizen of Philadelphia, Oct. 18, 1787, 13 Documentary History, supra note 253, at 297, 301, 303 (objections (1)-(2), (5)); Elbridge Gerry to the Massachusetts General Court, Mass. Centinel, Nov. 3, 1787, reprinted in 1 Bailyn's Debate, supra note 253, at 231-33 (objecting generally that "the judicial department will be oppressive"); The Federal Farmer 11I, N.Y. Journal, Nov. 8, 1787, reprinted in 1 Bailyn's Debate, supra note 253, at 259-74 (objections (1)-(3), (5), (6)); George Mason, Va. J., Nov. 22, 1787, reprinted in 1 Bailyn's Debate, supra note 253, at 345-49 (objections (1), (4), (5)); A Federal Republican, Nov. 28, 1787, 14 Documentary History 255, 267-69 (objections (1), (5)). Most of these early pamphlets were directly responding to Wilson's speech.

261. The Federalist No. 22, at 150 (Alexander Hamilton) (Clinton Rossiter ed., 1961); see A Landholder V [Oliver Ellsworth], A Further Reply to Elbridge Gerry, Conn. Courant, Dec. 3, 1787, reprinted in 1 Bailyn's Debate, supra note 253, at 239, 242-43.

262. The Federalist No. 37, at 229 (James Madison) (Clinton Rossiter ed., 1961). 
penned with the greatest technical skill, and passed on the fullest and most mature deliberation, are considered as more or less obscure and equivocal, until their meaning be liquidated and ascertained by a series of particular discussions and adjudications."263 Thus, a Supreme Court with final authority to construe federal statutes was necessary to both the rule of law and the operation of national statutory policies.

The Constitution's proponents left none of the critics' specific charges unanswered. Consider the Federalist response to George Mason's claim that the Constitution would effectively supersede state common law. ${ }^{264}$ James 1redell replied that the Constitution would change nothing, and the common law would remain the baseline for Americans' duties and rights, subject to lawful statutory alterations. 1ndeed, the Constitution's bar to ex post facto laws, Iredell said, would protect against retroactive legislative changes in property rights. "The principles of the common law, as they now apply, must surely always hereafter apply, except in those particulars in which express authority is given by this Constitution." 265 Madison made this point and the further one that the Constitution could not have proclaimed any rule as to the common law without disrupting the diverse decisions made by the several states as to how much and what part of the English common law they wanted to incorporate into their legal systems. ${ }^{266}$ Neutral lawyers would probably have confirmed Iredell's and Madison's observations. Mason's objection died and was scarcely heard from again.

The death of this objection was exceptional, however, for similar objections were made over and over again, incorporated into larger claims or simply reiterated. Consider the complex history of the charge that the consolidation of law and equity in Article III, Section 2 would increase the discretion of federal judges. The Federal Farmer ${ }^{267}$ early on claimed that "if the law restrain him [the judge], he is only to step into his shoes of equity, and give what judgment his reason or opinion may dictate."268 Timothy Pickering responded that the law/equity distinction went mainly

263. Id. Note the echo of Aristotle's idea that the role of the legislator is to issue general directives, with judges giving those directives meaning through application to concrete cases. See supra note 37 and accompanying text.

264. George Mason, Objections to the Constitution, Va. J., Nov. 22, 1787, reprinted in 1 Bailyn's Debate, supra note 253, at 346.

265. Marcus I-V [James Iredell], Answers to Mason's “Objections", Norfolk \& Portsmouth J., Feb. 20-Mar. 19, 1788, reprinted in 1 Bailyn's Debate, supra note 253, at 365.

266. Letter from James Madison to George Washington, Oct. 18, 1787, reprinted in 1 Bailyn's Debate, supra note 253, at 351 .

267. The identity of the Federal Farmer is contested. Some have thought this was the pen name for Richard Henry Lee, but Richard B. Bernstein argues that the Farmer's letters were penned by Melancton Smith. Richard B. Bernstein, Charting the Bicentennial, 87 Colum. L. Rev. 1565, 1592-93 (1987). Recall that Smith was one of the critics of Chief Judge Duane's decision in Rutgers v. Waddington.

268. Letter from The Federal Farmer to The Republican III, N.Y., Oct. 10, 1787, reprinted in 1 Bailyn's Debate, supra note 253, at 273. 
to the mode of trial and the kind of relief that could be granted; therefore, a grant of equitable authority did not open up new avenues for judicial thinking. He quoted these passages from Blackstone:

"It is also said, that a court of equity determines according to the spirit of the rule, and not according to the strictness of the letter. But so also does a court of law. Both, for instance, are equally bound, and equally profess, to interpret statutes according to the true intent of the Legislature."

"There is not a single rule of interpreting laws, whether equitably or strictly, that is not equally used by the judges in the courts both of law \& equity." - "Each endeavors to fix and adopt the true sense of the law in question; neither can enlarge, diminish, or alter that sense in a single tittle." 269

Note how Pickering's response is concrete confirmation of my earlier observations that English and American lawyers and jurists of the eighteenth century did not consider equitable interpretation to be an exercise of unbridled judicial discretion or lawmaking. ${ }^{270}$

Given the authority of Blackstone and the fatuous reading of Article III that the Farmer's objection represented, one would think that Pickering's response would have been decisive. It was not. One reason had to do with the nature of the debate over the Constitution. It was in some ways a national debate, with the leading letters and pamphlets disseminated throughout the country, but it was also a collection of local debates, and many documents were not widely read. ${ }^{271}$ I doubt many Americans read Pickering's response, and at the very point he was writing it several states were already ratifying the Constitution without the benefit of his arguments: Delaware on December 7, 1787, and Pennsylvania on December 12. The debate in Pennsylvania was highly contentious and touched on several judiciary issues, such as the right to jury trials in civil cases. The dissenters on December 18 promulgated their reasons. Chief among them was the fear of consolidation: Article I vested Congress with such "unlimited" powers as could easily be exercised to "swallow [the

269. Refutation of the "Federal Farmer": Timothy Pickering to Charles Tillinghurst, Phil., Dec. 24, 1787, reprinted in 1 Bailyn's Debate, supra note 253, at 289, 297 (quoting 3 Blackstone, supra note 39 , at $* 430-* 431$ ).

270. See Molot, supra note 252, at 32-41 (demonstrating that the supporters of the Constitution believed the judiciary was constrained by rules and precedents of both legal and equitable relief). But see Manning, Equity of the Statute, supra note 8 , at $85 \mathrm{n} .331$ (claiming that Pickering's response was an idiosyncratic Federalist defense of equitable interpretation but failing to cite a single Federalist author who disagreed with Pickering's observation). The only Federalist author Manning discusses is Hamilton, see id. at 81-84, whose performance in Rutgers and whose vigorous defense of equitable interpretation in The Federalist No. 78 strongly associate him with equitable interpretation's virtues, not its vices. See supra note 304-313 and acompanying text. Manning's view that Hamilton was a "faithful agent" theorist, see Manning, Equity of the Statute, supra note 8, at 83-84, is quite a stretch and is based on a quotation taken out of context, infra note 315 .

271. On the fragmentary nature of the debate, see Rakove, Original Meanings, supra note 14, at 132-34; Larry D. Kramer, Madison's Audience, 112 Harv. L. Rev. 611, 637-40 (1999). 
states] up in the grand vortex of general empire," while the judicial powers were "so various and extensive, that by legal ingenuity they may be extended to every case, and thus absorb the state judiciaries," a power grab allowed by the equitable powers given the federal courts. ${ }^{272}$ Rather than dying on the vine, as the "common law abrogation" objection had, the "law and equity" objection became one of the prominent and recurring points of contention between defenders and critics of the proposed Constitution. 273

After the Pennsylvania ratification, rapidly followed by New Jersey (December 18, 1787), Georgia (January 2, 1788), and Connecticut (January 4,1788 ), the next big battle was in Massachusetts (January 9 to February 6,1788 ). The reports we have of the debates suggest that relatively little discussion focused on the judiciary, even though relevant pamphlets were distributed at the convention and newspapers ran articles on the matter before and during the convention. ${ }^{274} \mathrm{~A}$ key argument against Article 11I was the "law and equity" one. Samuel Osgood asserted that the powers of the Supreme Court were "as indefinite \& unlimited as Words can make it." 275 The states would be helpless in the face of expansive congressional laws, which would be construed by the Court, and "they have Power, not confining themselves to the Letter of the general or State Constitutions, to consider \& determine upon it, in Equity," which would allow the Court to "make what Constitution they Please for the united States."276 Echoing Madison's The Federalist 37 (published during the Massachusetts Convention), Theophilus Parsons responded to this kind of claim that "no compositions which men can pen, could be formed, but what would be liable to the same charge" of ambiguity. ${ }^{277}$ Presumably others reassured undecided delegates that judges following ordinary rules of interpretation could be trusted with the task of application, as Hamilton and Madison had been arguing. Not only did the delegates ratify, but their mode of ratification suggests they did not consider Osgood's charge viable. Massachusetts initiated the practice of propounding desirable amendments to the Constitution at the time of its ratification; two of that state's nine amendments spoke to the jurisdiction and jury trial objections. ${ }^{278}$ Because the delegates failed to seek reassurances as to the obvious judicial power to consider equity and not just words, one might

272. The Address and Reasons of Dissent of the Minority of the Convention of the State of Pennsylvania to their Constituents, Penn. Packet, Dec. 18, 1787, reprinted in 1 Bailyn's Debate, supra note 253, at 526, 540 .

273. For different but useful accounts, see Powell, supra note 42, at 907-12; Yoo, Chancellor's Foot, supra note 85, at 1153-59.

274. See Goebel, Antecedents, supra note 190 , at $309 \&$ n.70, 348-49.

275. Letter from Samuel Osgood to Samuel Adams, N.Y., Jan. 5, 1788, reprinted in 1 Bailyn's Debate, supra note 253, at 704, 705-06.

276. 1d. at 706 .

277. 2 Elliot's Debates, supra note 253, at 104.

278. Ratification of the Federal Constitution of the Commonwealth of Massachusetts, Feb. 6, 1788, reprinted in 2 Bailyn's Debate, supra note 253, at 547, 549 . 
weakly infer that Osgood's public charge had no traction, even for some of the skeptical delegates.

During the Massachusetts debates, but presumably with an eye to the upcoming Virginia and New York conventions, the Federal Farmer made the "law and equity" argument part of a larger critique of the judicial power. ${ }^{279}$ His Letter XV started with the proposition that "judges and juries, in their interpretations, and in directing the execution of [laws adopted by the legislature], have a very extensive influence for preserving or destroying liberty, and for changing the nature of the government." 280 Even if we were to fix limits on the power, "it will yet be formidable, somewhat arbitrary and despotic - that is, after all our cares, we must leave a vast deal to the discretion and interpretation-to the wisdom, integrity, and politics of the judges." 281 The danger of judicial usurpation, the Farmer observed, is in one respect greater than the danger of legislative and executive usurpation. "A bad law immediately excites a general alarm; a bad judicial determination, though not less pernicious in its consequences, is immediately felt, probably, by a single individual only, and noticed only by his neighbours, and a few spectators in the court." ${ }^{282}$ For this reason, and the tendency of courts to cleave to their worst follies, "we are more in danger of sowing the seeds of arbitrary government in this department than in any other." 283

Having raised the stakes of Article 11I, the Farmer then analyzed its provisions. He agreed that there must be a supreme federal tribunal, in order to assure legal uniformity. The Farmer worried, however, that federal appellate authority over fact as well as law and the uncertainty of jury trials in federal cases would remove the most important check on arbitrary judging. ${ }^{284}$ These features of Article 111 reminded the Farmer of the civil law system-alien to Anglo-Saxon culture until imported through the "intrigues of the popish clergy, and of the Norman lawyers." 285 The other civil law (foreign) feature express in Article lII was of course the merging of law and equity in its judges. The Farmer confessed he did not know what the document meant by that, but it surely gave "the judge a discretionary power." He concluded with this example:

279. Federal Farmer XV, Jan. 18, 1788, in 2 The Complete Anti-Federalist, supra note 253, at 315. For other discussions of Letter XV, see Philip A. Hamburger, The Constitution's Accommodation of Social Change, 88 Mich. L. Rev. 239, 308 (1989); Todd D. Peterson, Restoring Structural Checks on Judicial Power in the Era of Managerial Judging, 29 U.C. Davis L. Rev. 41, 49-51 (1995).

280. Id.

281. Federal Farmer XV, supra note 279, at 315.

282. Id. at 316.

283. Id.

284. Id. at 319.

285. Id. at 320; cf. id. ("If the conduct of judges shall be severe and arbitrary, and tend to subvert the laws, and change the forms of government, the jury may check them, by deciding against their opinions and determinations, in similar cases."). 
Suppose a case arising under the constitution [concerning whether] congress can suppress a state tax laid on polls, lands, or as an excise duty, which may be supposed to interfere with a federal tax. By the letter of the constitution, congress will appear to have no power to do it: but then the judges may decide the question on principles of equity as well as law. Now, omitting the words, "in law and equity," they may decide according to the spirit and true meaning of the constitution, as collected from what must appear to have been the intentions of the people when they made it. ${ }^{286}$

Published less than two weeks later, Brutus's Letter Xl expanded the Farmer's argument. Article $11 \mathrm{l}$ was important to the dynamics of the proposed government, and the Constitution posed huge risks in creating a judiciary wholly outside the control of the people and the legislature-"a situation altogether unprecedented in a free country." ${ }^{87}$ Like the Farmer, Brutus asserted that the federal courts were authorized by the law and equity language to interpret statutes and the Constitution according to their own political views. In making this argument, Brutus contrasted the "law" mode of interpretation with the "equity" mode:

According to [the "law"] mode of construction, the courts are to give such meaning to the constitution as comports best with the common, and generally received acceptation of the words in which it is expressed, regarding their ordinary and popular use, rather than their grammatical propriety. Where words are dubious, they will be explained by the context. The end of the clause will be attended to, and the words will be understood, as having a view to it; and the words will not be so understood as to bear no meaning or a very absurd one. ${ }^{288}$

By the "equity" mode, in contrast, the Supreme Court could "explain the constitution according to the reasoning spirit of it, without being confined to the words or letter." 289 Brutus then quoted one of Blackstone's equitable rules for statutory interpretation:

the correction of that, wherein the law, by reason of its universality, is deficient; for since in laws all cases cannot be foreseen, or expressed, it is necessary, that when the decrees of the law cannot be applied to particular cases, there should some where be a power vested of defining those circumstances, which had they been foreseen the legislator would have expressed. ${ }^{290}$

286. Id. at 322 .

287. Brutus XI, N.Y. J., Jan. 31, 1788, reprinted in 2 Bailyn's Debate, supra note 253, at 129, 129 [hereinafter Brutus XI]; see also Brutus XV, N.Y. J., Mar. 20, 1788, reprinted in 2 Bailyn's Debate, supra note 253, at 372-73 [hereinafter Brutus XV] (asserting that while English judges "hold their offices during their good behavior," they do not control the government, because they have no authority to declare laws unconstitutional).

288. Brutus XI, supra note 287 , at 13 I.

289. Id.

290. Id. at I32 (quoting 1 Blackstone, supra note 39 , at $* 6 \mathrm{I}-* 62$ ). Note the echo of Plowden, see supra note 37 and accompanying text. 
The consequences of this equitable power to interpret laws and the Constitution were fearsome, according to its opponents. Such a power rendered the Court superior to Congress, because "the legislature themselves, cannot set aside a judgment of this court, because they are authorised by the constitution to decide in the last resort. The legislature must be controuled by the constitution," which Brutus suggested was malleable to whichever "spirit" the Court desired to invoke. ${ }^{291}$ Worse yet, not only would the Court be prone to increase its own jurisdiction through "equitable construction," but it would also encourage Congress toward aggrandizement, as the proliferation of usurpative federal statutes would increase the Court's authority as well. ${ }^{292}$ Even more than Congress, the states would be controlled by the courts, and their responsibilities would shrink. "This power in the judicial, will enable them to mould the government, into almost any shape they please."293 In Letter X11, Brutus elaborated on his fears of equitable constructions and concluded that "in proportion as the general government acquires power and jurisdiction, by the liberal construction which the judges may give the constitution, will those of the states lose its rights, until they become so trifling and unimportant, as not to be worth having." ${ }^{294}$ ln Letter XIII, however, Brutus conceded that he had no objection to federal courts having equitable powers, other than its contribution to the excessively broad federal legislative power. ${ }^{295}$

In Letter XIV, Brutus argued that the new federal judiciary would be dilatory, expensive, and bereft of jury trials, ${ }^{296}$ but he also made an interesting defensive point: The new federal judiciary was charged with nothing that the state courts could not do just as well. ${ }^{297}$ Coyly referring to Federalist arguments that state courts could not be trusted to adjudicate certain disputes (such as diversity of citizenship cases) impartially, Brutus pointed to the application of state laws allowing debts to be paid with worthless paper money. "All the acts of our legislature, which have been charged with being of this complexion, have uniformly received the strictest construction by the judges, and have been extended to no cases but to such as came within the strict letter of the law," limiting the law "as to

291. 1d. This theme is developed in greater detail in Brutus XV, supra note 287, at 375-78.

292. Brutus XI, supra note 287, at $133-34$.

293. Id. at 135. Arguing the prescience of Brutus's projections, see Paul Peterson, Antifederalist Thought in Contemporary American Politics, in Antifederalism: The Legacy of George Mason 111, 121-26 (Josephine F. Pacheco ed., 1992).

294. Brutus XII, N.Y. J., Feb. 7 \& 14, 1788, reprinted in 2 Bailyn's Debate, supra note 253, at $171,177$.

295. Brutus XIII, N.Y. J., Feb. 21, 1788, reprinted in 2 Bailyn's Debate, supra note 253, at 222-24 (accepting the Supreme Court's jurisdiction in law and equity over federal question cases but expressing bewilderment as to how such power would operate as to treaties).

296. Brutus XIV, N.Y. J., Feb. 28 \& Mar. 6, 1788, reprinted in 2 Bailyn's Debate, supra note 253 , at $258,263$.

297. 1d. at $264-65$. 
work the least possible injustice."298 Indeed, referring to Trevett $v$. Wee$d e n,{ }^{299}$ he noted that Rhode 1sland judges "gave a decision, in opposition to the words of the Statute, on this principle, that a construction according to the words of it, would contradict the fundamental maxims of their laws and constitution." 300 Brutus invoked these examples with approval, to show that impartiality and protection of vested rights against state legislative usurpation were values that the state courts already enforced in full measure-without the need for a new layer of federal judges.

By March 1788, therefore, an elaborate Anti-Federalist attack on the Constitution's judicial power article had been developed. 1 doubt that many Americans changed their minds about the Constitution after reading these letters, nor do I doubt that this was a serious indictment the Federalists needed to answer. Hamilton, as Publius, answered the various arguments in The Federalist Nos. 78-83, all published on May 28, 1788, just before Virginia and New York convened their ratifying conventions. There is much common ground with Federal Farmer, as Publius argued "the mere necessity of uniformity in the interpretation of the national laws" and treaties and the arbitration of interstate disputes as requiring a national judiciary. ${ }^{301}$ There was even common ground with the more contentious Brutus, for Publius agreed that the federal courts would have the power of judicial review over both state laws and national legislation. ${ }^{302}$ He strenuously denied that this power would enable the judiciary to dominate ("control") the states and the national legislature.

The Federalist No. 78 defended the independence of the judiciary and justified judicial review and liberty-protecting statutory constructions. Publius's primary argument was that the judiciary, possessing neither the power to tax nor the power even to enforce its own judgments, was "the least dangerous" branch, much less to be feared than Congress, ${ }^{303}$ which in any event had a powerful impeachment check against runaway judges. ${ }^{304}$ For my inquiry, his more pertinent argument was that the federal judiciary was a needed check on the legislature to protect the liberties of the people themselves. When the Supreme Court invalidated a statute it was reasserting the power of the people-not of the judges-to

298. Id.

299. See supra note 190 and accompanying text.

300. Brutus XIV, N.Y. J., Feb. 28 \& Mar. 6, I788, reprinted in 2 Bailyn's Debate, supra note 253, at 264.

301. The Federalist No. 80, at 476 (Alexander Hamilton) (Clinton Rossiter ed., 1961).

302. See The Federalist No. 78, at 434-35 (Alexander Hamilton) (Clinton Rossiter ed., 196I) (making the argument for judicial review ultimately adopted in Marbury v. Madison, 5 U.S. (I Cranch) 137 (1803)).

303. The Federalist No. 78, at 465 (Alexander Hamilton) (Clinton Rossiter ed., I96I).

304. The Federalist No. 81, at 484-85 (Alexander Hamilton) (Clinton Rossiter ed., I961). 
control their wayward, and perhaps temporarily misguided, agents. ${ }^{305}$ Publius applied the same libertarian idea to statutory interpretation:

These [ill humours of the political system] sometimes extend no farther than to the injury of the private rights of particular classes of citizens, by unjust and partial laws. Here also the firmness of the judicial magistracy is of vast importance in mitigating the severity, and confining the operation of such laws. It not only serves to moderate the immediate mischiefs of those which may have been passed, but it operates as a check upon the legislative body in passing them; who, perceiving that obstacles to the success of an iniquitous intention are to be expected from the scruples of the courts, are in a manner compelled by the very motives of the injustice they meditate, to qualify their attempts. ${ }^{306}$

Agreeing with Brutus's praise for state judicial narrowing of unjust statutes and recalling his own triumph in Rutgers $v$. Weddington, ${ }^{307}$ Publius (Hamilton) marvelled at how " $[t]$ he benefits of the integrity and moderation of the judiciary have already been felt in more states than one" and, although controversial in some circles, were applauded by "all the virtuous and disinterested." 308

The Federalist No. 78 then addressed the Anti-Federalist fear that "the courts on the pretense of a repugnancy [with the Constitution], may substitute their own pleasure to the constitutional intentions of the legisla-

305. See The Federalist No. 78, at 467 (Alexander Hamilton) (Clinton Rossiter ed., 1961). Hamilton hypothesized that unconstitutional laws would often be the result of "ill humours which the arts of designing men, or the influence of particular conjunctures, sometimes disseminate among the people themselves," which may "occasion dangerous innovations in the government, and serious oppressions of the minor party in the community." Id. at 469. See also Madison's The Federalist No. 10, which showed how temporary majorities could form to deprive individuals and groups of their vested rights and liberties. The Federalist No. 10, at 77-78 (James Madison) (Clinton Rossiter ed., 1961).

306. The Federalist No. 78, at 470 (Alexander Hamilton) (Clinton Rossiter ed., 1961) (emphasis added); see also The Federalist No. 81, at 451 (Alexander Hamilton) (Clinton Rossiter ed., 1961) ("From a body [the legislature] which had had even a partial agency in passing bad laws, we could rarely expect a disposition to temper and moderate them in the application."). Manning, Equity of the Statute, supra note 8, at 82, interprets this language to reflect the power of judges to mitigate only when laws were ambiguous. There is nothing in those passages to support such a view. Moreover, Manning's gloss is inconsistent with Hamilton's own experience in Rutgers $v$. Waddington, see supra note 169 and accompanying text (which was probably one inspiration for the statement), and with the conclusions that most serious scholars have drawn from the passage. See, e.g., David F. Epstein, The Political Theory of The Federalist 188-90 (1984) (drawing from this and other passages the conclusion that the Framers generally endorsed a liberal, equity-based approach to statutory interpretation).

307. See supra note 169 and accompanying text.

308. The Federalist No. 78, at 470 (Alexander Hamilton) (Clinton Rossiter ed., 1961); see also The Federalist No. 81, at 452 (Alexander Hamilton) (Clinton Rossiter ed., 1961) (praising those states that had placed the judicial power in an independent body). 
ture."309 Publius immediately noted that this will invariably happen "in the case of two contradictory statutes" and might happen in any "adjudication upon any single statute." 310 With some distance from his own views, he acknowledged the Anti-Federalist view that "courts must declare the sense of the law; and if they should be disposed to exercise WILL instead of JUDGMENT, the consequence would equally be the substitution of their pleasure to that of the legislative body." 311 It is not clear whether Publius agreed with this position as a normative matter, for he simply restated what he heard others saying and opined only that its logic "would prove that there ought to be no judges distinct from that body," namely the legislature. ${ }^{312}$ Obviously that was an unacceptable option, so one is left with the implication that the modern "agency problem" may be a price of an independent judiciary. But Publius insisted that this was a price worth paying; the only alternative to a judiciary which risked judicial legislation would be an unregulated legislature that enacted unjust and unconstitutional laws at its own pleasure. He also suggested, at the end of the essay, that this would not be a big problem because there were professional constraints on judges, especially precedents and rules that guided their discretion. ${ }^{313}$ Indeed, most lawyers reading The Federalist 78 would have known that Bacon's Abridgment and Blackstone's Commentaries 1961).

309. The Federalist No. 78, at 468-69 (Alexander Hamilton) (Clinton Rossiter ed.,

310. Id. at 469.

311. Id. Manning reads this language as evidence of Hamilton's "unmistakable suspicion of judicial discretion," which Manning considers "sharply at odds with the premises of the equity of the statute." Manning, Equity of the Statute, supra note 8 , at 83 . This conclusion is questionable, partly because it is not clear what Hamilton's normative stance was toward the statement in the text. More important, it is clear that discretion per se was not disapproved of by the author. Earlier in the same essay, Publius approvingly spoke of the "exercise of judicial discretion in determining between two contradictory laws," The Federalist No. 78, at 468 (Alexander Hamilton) (Clinton Rossiter ed., 1961), and later in the essay disapproved only of "an arbitrary discretion in the courts," id. at 471 (emphasis added). To the extent discretion was a problem, Publius saw the antidote as being "strict rules and precedents," id., such as those laid down in Blackstone and Bacon for equitable as well as other modes of interpretation. Moreover, the distinction between "will" and "judgment" was not necessarily a distinction between "equity" and "law," as Manning might be read to suggest. Instead, it probably distinguished between a judge's imposing his own "political preference" (to use a modern term) onto the words of a statute, as opposed to the judge's applying established precedents, common law and international law baselines, and common sense to figure out how statutes ought to apply in the context of concrete cases. An exercise of "judgment"-not "will"-is how Hamilton would likely have characterized Chief Judge Duane's opinion in Rutgers, the crowning moment in Hamilton's career as a lawyer and the most elaborate example of equitable interpretation in the $1780 \mathrm{~s}$.

312. The Federalist No. 78, at 469 (Alexander Hamilton) (Clinton Rossiter ed., 1961).

313. See id. at 471 ("To avoid an arbitrary discretion in the courts, it is indispensable that they should be bound down by strict rules and precedents, which serve to define and point out their duty in every particular case that comes before them ...."); see generally Molot, supra note 252, at 34-41 (discussing the passage's implications for statutory interpretation). 
laid out dozens of canons of statutory construction, including canons to guide judges in the exercise of their equitable glosses on statutes.

The Federalist No. 81 addressed Brutus's argument that, by equitable construction of the Constitution, the judiciary could mold the government into any shape it desired. In the Federalist No. 81, Publius wrote:

In the first place, there is not a syllable in the plan under consideration, which directly empowers the national courts to construe the laws according to the spirit of the constitution, or which gives them any greater latitude in this respect, than may be claimed by the courts of every state. I admit however, that the constitution ought to be the standard of construction for the laws, and that wherever there is an evident opposition, the laws ought to give place to the constitution. ${ }^{314}$

Note Hamilton's explicit association of how Article 111 empowered federal courts to interpret statutes and how state courts of the 1780 s were interpreting statutes in cases like Rutgers and Trevett. If state judges have behaved responsibly, as Brutus himself maintained, why should we expect federal judges to be usurpative in the way Brutus asserted? Also, Hamilton in this passage was reassuring readers that the judiciary would not enlarge federal statutes to meet constitutional allowances, but stood always ready to narrow statutes in tension with the commands of fundamental law. Consistent with all the other Federalist statements about the judiciary, Hamilton's defense of the new federal "judicial Power" was that it would be exercised the way Anglo-American courts had been responsibly exercising power-but with the added check of a written Constitution that would make the fundamental law more concrete and lawlike.

The Federalist Nos. 78 and 81 were Hamilton's primary response to Brutus's argument, but he had several others as well. Publius implicitly conceded that the courts would sometimes act contrary to "the will of the legislature," but "particular misconstructions and contraventions of the will of the legislature can never be so extensive as to amount to an inconvenience, or in any sensible degree to affect the order of the political system." 315 He claimed that there were other checks to assure that judges

314. The Federalist No. 81, at 482 (Alexander Hamilton) (Clinton Rossiter ed., 1961).

315. ld. at 484-85. Because Hamilton referred to "misconstructions . . . of the will of the legislature," Manning reads this passage as support for "the faithful agent theory, rather than the equity of the statute." Manning, Equity of the Statute, supra note 8, at 83-84. For reasons already rehearsed, Federalists like Hamilton did not see a conflict between equitable interpretation and legislative supremacy; Brutus and Federal Farmer (the losers in the ratification debates) were in the minority on this point. Also, this passage in The Federalist No. 81 is normatively ambiguous: Publius does not unequivocally condemn the occasional "misconstruction," he just shows how the legislature ought not to fear them. (A few sentences later, Publius took a clearer normative stand against "a series of deliberate usurpations," The Federalist No. 81, at 485 (Alexander Hamilton) (Clinton Rossiter ed., 1961)). Moreover, this passage must be read against the backdrop of The Federalist No. 78, published the same day, which explicitly rejected the premises of what Manning calls the faithful agent theory: "[T] he courts were designed to be an intermediate body between the people and the legislature, in order . . . to keep the latter 
would not grab power under the guise of either statutory or constitutional constructions: "the general nature of the judicial power" and "the manner in which it is exercised"; the "comparative weakness" of the judiciary vis-à-vis the political branches; and the possibility of impeachment, which "is alone a complete security." ${ }^{16}$ Note that Publius only answered half, and the lesser half, of Brutus's complaint: While the Supreme Court might be cautious in pressing its authority vis-à-vis Congress, Publius presented few if any reasons to think the Court would not work with Congress to marginalize or even abrogate state authority.

In other papers published on May 28, Publius defended Article III's prohibition against salary reduction ${ }^{317}$ and its extensive heads of federal jurisdiction, ${ }^{318}$ and refuted the claims that state courts would lose jurisdiction over cases within the heads of federal jurisdiction ${ }^{319}$ and that people's right to civil trial by jury would not be abrogated or abridged. ${ }^{320}$ The May 28 Federalist papers constituted not only the Federalist response to Brutus's and Federal Farmer's critiques of Article III and the "judicial Power" it created, but also set forth the position defended by the Federalists in the Virginia and New York conventions.

The judicial power and fears of extensive judicial review were discussed at length at the Virginia convention, albeit in fairly general terms. ${ }^{321}$ George Mason linked the judicial power to the general charge that consolidated government would destroy the states and individual liberties. $^{322}$ Mason's arguments were often iguorant and were never as

within the linits assigned to their authority," The Federalist No. 78, at 467 (Alexander Hamilton) (Clinton Rossiter ed., 1961); the "will of the legislature declared in its statutes," is subordinate to the will of the people, declared in the Constitution, and judges are ultimately agents only of the latter, id. at 468 ; a firm commitment to the people equally well undergirds the obligation of judges in normal statutory interpretation cases to mitigate the severity and confine the operation of "unjust and partial laws," id. at 470 . Finally, Manning's claim is inconsistent with the deeper account of Hamilton's ideology in David McGowan, Ethos in Law and History: Alexander Hamilton, The Federalist, and the Supreme Court, 85 Minn. L. Rev. 755, 755-60 (2001).

316. The Federalist No. 81, at 485 (Alexander Hamilton) (Clinton Rossiter ed., 1961).

317. The Federalist No. 79, at 472 (Alexander Hamilton) (Clinton Rossiter ed., 1961).

318. The Federalist No. 80, at 475-81 (Alexander Hamilton) (Clinton Rossiter ed., 1961).

319. The Federalist No. 82, at 492-95 (Alexander Hamilton) (Clinton Rossiter ed., 1961).

320. See The Federalist No. 81, at 489-91 (Alexander Hamilton) (Clinton Rossiter ed., 1961) (arguing that Supreme Court's appellate jurisdiction will "extend in the broadest sense to matters of fact," though "subject to such exceptions as the natural legislation may prescribe regarding factual findings made by juries"); The Federalist No. 83, at 498-99 (Alexander Hamilton) (Clinton Rossiter ed. 1961) (arguing that silence of Constitution in regard to civil causes is not abolition of trial by jury, with exception of cases in admiralty, which already were determined under existing government without use of jury).

321. See Kramer, supra note 255, at 124 n.5 (listing sources).

322. See George Mason, Address to the Virginia Convention (June 4, 1788), reprinted in 2 Bailyn's Debate, supra note 253, at 605, 609 (making general charge); George Mason, Address to the Virginia Convention (June 19, 1788), reprinted in 2 Bailyn's Debate, supra 
clever as those of Brutus, but he did press the view that Article III courts would "tend[ ] to impair and ultimately destroy the State Judiciaries, and by the same principle, the legislation of the State Governments." 323 Young John Marshall answered Mason's long list of charges with a series of rhetorical questions revealing their flaws. ${ }^{324}$ For example, in response to Mason's argument that the federal government would execute laws tyrannically, Marshall queried, "If a law be executed tyrannically in Virginia, to what can you trust? To your Judiciary. What security have you for justice? Their independence. Will it not be so in the Federal Court?" 325 It seems doubtful that the judicial tyranny arguments had any traction in the convention. Virginia's ratification, like that of Massachusetts before it and New York later, included a list of suggested amendments to the Constitution, including several relating to the judiciary, but none seeking to compromise judicial independence or the power of federal judges to declare state as well as federal laws void and unconstitutional. Indeed, Edmund Randolph, a key moderate whose support for the Constitution was pivotal, emphasized the libertarian value of the independent judiciary. "If Congress wish to aggrandize themselves by oppressing the people, the Judiciary must first be corrupted."326

The records we have for the New York convention barely mentioned the judiciary article-itself a remarkable development. One might (weakly) infer that Hamilton's May 28 response to the Federal Farmer and Brutus had been so persuasive as to remove the judiciary as an important focus of concern about excessive power in the federal government. ${ }^{327}$ The debate instead focused on issues such as insufficient separation of powers in the national government. By this point, Madison had articulated the Federalist position, which emphasized the way in which the different branches were "connected and blended, as to give to each a constitutional controul over the others." ${ }^{328}$ Hamilton took the same position at the New York Convention. Critics of the Constitution objected that the document offered too few protections against tyranny by Con-

note 253, at 720, 720-29 (making extensive argument that various features of Article III would undermine state governance).

323. George Mason, Address to the Virginia Convention (June I9, 1788), reprinted in 2 Bailyn's Debate, supra note 253, at 720, 726.

324. John Marshall, Address to the Virginia Convention (June 20, 1788), reprinted in

2 Bailyn's Debate, supra note 253 , at $730,730-41$.

325 . Id. at 738 .

326. 3 Elliot, supra note 253 , at 205.

327. This inference would be bolstered somewhat more if Melancton Smith, the main speaker critical of the Constitution in the New York debates, were the author of the Federal Farmer's letters, as Bernstein argues. See Bernstein, supra note 267, at 1592-93. (Smith had also been a critic of Rutgers.) Smith's questions about the Constitution focused overwhelmingly on Congress and the representation therein and made no objection to Article III, judicial independence, or equitable construction. See Melancton Smith, Address to the New York Ratifying Convention (June 2I, 1788), reprinted in 2 Bailyn's Debate, supra note 253 , at $757-65,773-75$.

328. The Federalist No. 48, at 308 (James Madison) (Clinton Rossiter ed., 1961). 
gress, which might regulate and tax the states out of existence. Hamilton responded that the separation of legislative, executive, and judicial powers and the federal structure constituted the best assurance anyone could devise to protect citizens' liberties. ${ }^{329}$ The goal of the constitutional structure of separated and balanced powers was to make the government's organization "so complex, so skilfully contrived, that it is next to impossible that an impolitic or wicked measure should pass the scrutiny with success." ${ }^{330}$ In such an organization, people's liberty was protected in three ways from hasty or undue encroachment by the federal government: Congress could not even act without agreement from two differently constituted chambers; the President, armed with a national constituency and a broader view, could block most measures through a veto; and the Court could narrow or invalidate unjust and partial laws. The Federalists had coalesced around this account, and it was a winner. Not only did New York ratify, but its proposed amendments, like those in Massachusetts and Virginia, omitted any mention of trimming back the judiciary's equity power. ${ }^{331}$ After New York ratified, the union was virtually complete. After much delay, North Carolina and Rhode lsland bowed to the inevitable and ratified in November 1789 and May 1790, respectively. ${ }^{332}$

Consider the foregoing account of the ratification debates in light of my three categories of nonliteral judicial power exercised by English judges before 1776. The Anti-Federalists' attacks focused on the judiciary's purported threat to common law liberties and state autonomy. Accordingly, they objected mainly to a voidance power by which judges would hold state laws unconstitutional and to a suppletive power by which federal judges would interpret federal law broadly to derogate from state authority and individual rights. Heydon's spirit-based interpretation ex-

329. Alexander Hamilton, Address to the New York Convention (June 21, 1788) reprinted in 2 Elliot's Debates, supra note 253, at 251, 257-58. Hamilton carried the debate for the supporters of the Constitution, against attacks from a variety of speakers. He was joined in support of the Constitution by Duane, the judge who decided Rutgers.

330. Alexander Hamilton, Address to the New York Convention (June 27, 1788) reprinted in 2 Bailyn's Debate, supra note 253, at 348.

331. New York's complex deal ratifying the Constitution included a series of declarations as to that state's understanding of the Constitution, reprinted in 2 Bailyn's Debate, supra note 253 , at $536-40$, as well as proposed amendments, id. at 540-45. The declarations expressed the delegates' understanding that the Constitution would not undermine jury trial rights, abrogate the states' sovereign immunity from suits, or enlarge federal court jurisdiction "by any fiction, collusion, or mere suggestion." 1d. at 539. The proposed amendments focused on reducing the heads of federal court jurisdiction. 1d. at 540-45.

332. See Rakove, Original Meanings, supra note 14, at 127-28. The delegates at the first North Carolina convention debated the old charge that the Constitution was vague and broadly phrased. E.g., 4 Elliot's Debates, supra note 253, at 55-56 (Timothy Bloodworth); see also id. at 136-39 (Spencer) (objecting to broad jurisdiction of federal courts). The Federalists insisted that interpretation would proceed according to the "maxim [s] of universal jurisprudence, of reason and common sense," and would follow "plain, obvious" constructions. 1d. at 71 (John Steele). 
panding upon either constitutional or federal statutory texts was the object of attack, but neither Bonham's Case nor Eyston v. Studd was drawn into question as a legitimate approach to statutory interpretation. Thus, no leading Anti-Federalist objected to a federal judicial power to void or narrowly construe national laws traversing the jurisdictional or other limits of the Constitution, and their widespread insistence on a bill of rights was premised on the desirability of federal judges' having authority to invalidate congressional enactments or to give them a narrowing construction so as to protect the liberty and property of the people. ${ }^{333}$ Nor did any Anti-Federalist writer object to the federal courts having ameliorative powers, that is, authority to read nontextual exceptions and limitations into broadly written congressional enactments.

Responding to these attacks, the Federalists emphasized the ways in which constitutional and statutory interpretation by an independent judiciary served libertarian goals and denied that the judiciary posed a significant threat to state autonomy. Accordingly, the leading authors claimed that the voidance power protected against usurpative legislation at both state and national levels, and implicitly favored a judicial authority to interpret federal laws narrowly in order to avoid constitutional infractions. ${ }^{334}$ Likewise, they explicitly embraced judges' ameliorative powers to argue that federal judges would-as state judges had been doingmitigate the severity and confine the operation of "unjust and partial laws." 335 The Federalists did not explicitly speak of the suppletive power or Heydon's Case. Their main strategy as to possible supplementations was avoidance and minimization. Thus, they maintained that broad interpretations of federal jurisdiction or substantive law would not be serious enough to abandon the other advantages of an independent federal judiciary. Although his normative stance toward judicial discretion was somewhat ambiguous, Hamilton sought in The Federalist 78 to reassure moderates that judges would not always or in most cases substitute their policy preferences ("WILL") for those of the legislature, but instead would usually exercise their powers in conformity with precedent and established rules ("JUDGMENT") - just as the state courts had been doing in the 1780 s.

333. Brutus's favorable mention of Trevett $v$. Weeden, see supra note 300 and accompanying text, can be read as an endorsement of this idea by the leading AntiFederalist writer on the judiciary. Even Jefferson came around to the idea that there should be a judicially enforceable Bill of Rights. See Letter from Thomas Jefferson to James Madison (Mar. 15, 1789), in 14 The Papers of Thomas Jefferson 659, 659-60 (Julian P. Boyd ed., 1958).

334. Given his experience in Rutgers, Hamilton would have been sympathetic to this variation, and his praise for state judicial narrowing of debtor-relief laws also supports such a notion. See supra note 315 and accompanying text.

335. The Federalist No. 78, at 470 (Alexander Hamilton) (Clinton Rossiter ed., 1961); see Epstein, supra note 306, at 189-90 (stating that Hamilton and other Federalists went so far as to urge that courts sometimes ought to be "lenient against the lawmakers' intention"). 
My account of the ratifying debates suggests a few hypotheses. To begin with, there was a relative consensus among the active debaters that federal courts would have voidance powers under the Constitution, and there was surprisingly little controversy about whether federal courts should narrow federal statutes to the extent they were inconsistent with the Constitution. Some Anti-Federalists did dispute the power of federal courts to void or narrowly interpret state laws. But they lost. Every state ratified the Constitution, notwithstanding their arguments. The most the Anti-Federalists could claim were proposed constitutional amendments endorsed by the Massachusetts, Virginia, New York, and a few other conventions-but none of those conventions made any proposal to narrow the authority of federal courts to review or interpret state or federal laws for consistency with the Constitution.

There was little discussion about any ameliorative powers federal judges would have, which is remarkable in light of the thorough scouring of Article III by its critics (Centinel, Mason, Federal Farmer, Brutus). What discussion there was suggests agreement in favor of such a power. Brutus, the leading critic of Article III, and Publius, the leading defender, both explicitly maintained that judges have and ought to have the power to give statutes narrowing constructions. One of Publius' main arguments in favor of judicial independence was that it would give federal judges freedom to mitigate the effect of "unjust and partial laws." No one questioned the rule of lenity, nor did any debater ever question the authority of Blackstone and Bacon, whose canons of statutory construction were libertarian and protective of common law rights.

In contrast, federal courts' suppletive powers were attacked-and defended weakly or indirectly. Critics like Federal Farmer and Brutus worried that federal courts would not only allow Congress to pass usurpative laws invading individual liberties and state authority but would also add to the usurpation by expansive interpretations of federal legislative (Article I) and judicial (Article III) jurisdiction. Publius nowhere defended expansive interpretation of either the Constitution or federal statutes. His apparent disclaimer that judges would exercise "JUDGMENT" rather than "WILL" can be read as a claim that judges would not themselves be an engine for expanding the federal government at the expense of the states or citizens. Some Federalists (such as Marshall) at the state ratifying conventions denied that the judicial power authorized federal judges to expand statutes. On the other hand, none of the Federalists retreated from the authority of Heydon's Case, and none denied the desirability of federal judges' expanding statutes, incrementally, to fill in gaps with precepts drawn from "fundamental law." ${ }^{366}$ If the ratifying debates are inconclusive as to any matter, it is the suppletive power. They are clear as to, and entirely supportive of, the ameliorative and voidance powers.

336. Cf. The Federalist No. 78, at 468 (Alexander Hamilton) (Clinton Rossiter ed., 1961) ("[Judges] ought to regulate their decisions by the fundamental laws, rather than by those which are not fundamental."). 


\section{Early Statutory Interpretation by Federal Judges, 1791-1806}

It might be informative to investigate the early practice of statutory interpretation by federal judges. How did the first men to exercise the "judicial Power" under Article III view their authority, and how did they actually interpret statutes? Generally, the utility of practical interpretations in illuminating original Constitutional expectations or meaning is greatest when a public discussion settling a matter left ambiguous occurred within a few years after the Constitution went into effect. ${ }^{337}$ Unannounced or undebated understandings that crept into federal practice a decade or more after the founding have much less (if any) value in discerning original constitutional expectations. As this Part demonstrates, judicial practices in the first several years, or even the first decade, after the ratification of the Constitution went into effect simply confirm the points I have already made. Manning claims that the statutory practice of the Marshall Court (1801-1835) represented a "shift to the faithful agent theory as the dominant constitutional foundation of statutory interpretation," whereby "federal judges had an affirmative duty to decipher and enforce, rather than improve upon, statutory commands-provided that they were clear in context." 338 The Marshall Court does not provide the most illuminating evidence of the Framer's original expectations of 1787-1789, because of the historical distance and because of that Court's unique circumstances. Nonetheless, I will examine the early statutory decisions by Chief Justice John Marshall, which do evidence a shift in style, but not entirely of the sort that Manning describes.

During the first decade of experience with the judicial power, the federal judiciary's legitimacy had to be earned rather than sustained. The presidencies of George Washington and John Adams made that process harder by embroiling judges in unpopular causes. These administrations urged the Supreme Court to abrogate the states' common law immunities from suit, dragooned Chief Justice Jay to negotiate a new treaty with England, prosecuted political enemies under the Seditious Libel Act of 1798 , and finally sought to stack the judiciary with Adams-Federalists after losing the election of $1800 .^{339}$ The latter election created fresh problems, as the victorious Jefferson-Republicans engaged in a campaign to reduce the power of the national judiciary and purge it of leading Federalists. The first fifteen years were rocky ones for the federal judici-

337. The leading case is McCulloch v. Maryland, 17 U.S. (4 Wheat.) 159 (1819). The Court found it instructive that the first Congress, after full and open debate, and the first President, after debate within his cabinet, authorized the first Bank of the United States. See also Myers v. United States, 272 U.S. 52, 174-76 (1926) (arguing that weight will be given to the First Congress's interpretation of the Constitution because these Congressmen were contemporaries of the Framers of the Constitution); Wisconsin v. Pelican lns. Co., 127 U.S. 265, 297 (1888) (same).

338. Manning, Equity of the Statute, supra note 8 , at 86; see id. at 85-102.

339. See Goebel, Antecedents, supra note 190, at $641-51,722-93$. On the travails and emerging party politics of this consolidating period, see Stanley Elkins \& Eric McKitrick, The Age of Federalisin 257-302 (1993). 
ary, truly the "least dangerous branch" of the fledgling national government.

Another important feature was that the federal judiciary, even more than the state courts, started from scratch. The Judiciary Act of 1789 created a politically balanced structure for the judiciary. ${ }^{340}$ The new law exercised Congress' authority to create inferior federal courts, but organized the judiciary in ways that were sensitive to the states' rights and individual liberty objections of the Anti-Federalists. District courts were vested with jurisdiction over federal crimes, foreigners accused of torts violating the law of nations or a treaty of the United States, suits by the United States at common law, and admiralty and maritime actions; in all but the last, jury trials were provided for ${ }^{341}$ Circuit courts had jurisdiction over diversicy cases, but only if the amount in controversy exceeded $\$ 500$, a large sum in those days, and cases where the United States was a party. ${ }^{342}$ These courts also had jurisdiction over most appeals from district court rulings. The Supreme Court had original jurisdiction as set forth in Article 11I, Section 2 and over specified appeals, including cases where the highest court of a state had found a federal law or treaty invalid, had upheld a state law against claims of inconsistency with federal law, or had interpreted a federal constitutional, statutory, or treaty provision. ${ }^{343}$ Although the Act borrowed concepts from equity, it forbade federal judges from granting injunctions unless it was completely clear that there was no remedy at law. ${ }^{344}$ Section 34 of the Act provided that unless there was a federal law on point, state laws would provide the "rules of decision" in federal cases. ${ }^{345}$ Although the Act contemplated Supreme Court review of state laws, it did not otherwise establish a structure that invited rampant nationalization of law. Nor did the Judiciary Act even assure nationalization of procedure in federal courts, for the Process Act of 1789 directed that procedures in federal cases at common law should be those of the state in which the court was sitting. ${ }^{346}$

Unlike the English and state cases discussed above, the early federal cases almost always involved recent statutes or treaties. That the new statutes were sometimes badly drafted made the interpretive task harder.

340. See Judiciary Act of 1789, ch. 20, 1 Stat. 73 (1789). The best examinations of the new law are Goehel, Antecedents, supra note 190, at 458-508; Henry J. Bourguignon, The Federal Key to the Judiciary Act of 1789, 46 S. Cal. L. Rev. 647, 667-700 (1995); Maeva Marcus \& Natalie Wexler, The Judiciary Act of 1789: Political Compromise or Constitutional Interpretation, in Origins of the Federal Judiciary: Essays on the Judiciary Act of 1789, at 13 (Maeva Marcus ed., 1992); Charles Warren, New Light on the History of the Federal Judiciary Act of 1789, 37 Harv. L. Rev. 49, 131 (1923).

341. $\S 9,1$ Stat. at 76-77.

342. $\S 11,1$ Stat. at $78-79$

343. $\S 13,1$ Stat. at $80-81$. Note that $\S 13$ assumes that state courts will exercise avoidance power and vests the Supreme Court with such a power.

344. $\S 16,1$ Stat. at $82-83$.

345. $\S 34,1$ Stat. at 92 .

346. Act of Sept. 29, 1789, ch. 22, 1 Stat. 94 (1789); see Goebel, Antecedents, supra note 190, at 509-40 (describing drafting history of the Process Act). 
Their contemporaneity made the task easier, because most of the big issues were settled by the statutory text or by congressional negotiations that were known to the judges deciding the cases; the unforeseen circumstances requiring judicial interpolation were typically minor. That the statutes being interpreted by Federalist judges (James Wilson, John Jay, William Paterson, James 1redell, Oliver Ellsworth, Bushrod Washington, and later John Marshall) were for the most part drafted by comrades in the ratification campaign (such as Ellsworth and Hamilton) also lessened at least some of the potential conflicts between statutes as written and as applied, because the drafters and interpreters were on the same political as well as intellectual wavelengths.

\section{A. The Jay and Ellsworth Courts, 1789-1801}

Although memorialized with few reported cases ${ }^{347}$ and little speechifying about method in any but the most eventful decisions, the first decade of federal court statutory decisions bespeaks strong continuity with the English and American state court practice surveyed above. Generally, the decisions attended to statutory words read in light of other provisions or statutes, the legislative intent and the spirit of the statute, the law of nations, constitutional precepts, and the common law. Not infrequently, these contextual sources yielded a statutory meaning that went beyond or against the enacted words. Interpretations invoking equity and statutory spirits continued to flourish, increasingly under the aegis of fundamental principles embodied in the Constitution.

An early public statement by James Wilson, one of the most active debaters at Philadelphia, the mastermind of Pennsylvania's ratification of the Constitution, and one of the first Justices of the Supreme Court, illustrates the interpretive theory then prevalent:

In making laws, it is impossible to specify or to foresee every case: it is, therefore, necessary, that, in interpreting them, those cases should be excepted, which the legislator himself, had he foreseen them, would have specified and excepted. Such interpretation, however, ought to be made with the greatest circumspection. By indulging it rashly, the judges would become the arbiters, instead of being the ministers of the laws. 1t is not to be used, unless where the strongest and most convincing reasons appear for using it. A strong reason for using it is drawn from

347. See 2 U.S. (2 Dall.) and 3 U.S. ( 3 Dall.) for the Supreme Court decisions and most of the reported lower federal court decisions. Goebel, Antecedents, supra note 190, at 552-721, discusses a number of unreported Supreme Court and lower court decisions. As in my survey of state cases in Part 1I, my survey of federal cases in this Part is not a complete sample, because I did not read the unreported or the unwritten decisions. I offer the analysis in this Part as evidence that federal judges continued to exercise the nonliteralist authority exercised by English and state judges before 1789. At the very least, my survey requires more evidence from Manning to establish his claim that federal judges were confused and their methodology inconclusive during this period. Manning, Equity of the Statute, supra note 8, at 86-88. 
the spirit of the law, or the motive which prevailed on the legislature to make it. When equity is taken in this sense, every court is also a court of equity. ${ }^{348}$

Note the rhetorical echo of Plowden and Aristotle. This was a modest expression of equity-influenced thinking and did not present itself as judicial lawmaking. Consistent with the ratifying debates, this stance toward statutes was seen as part of the rule of law that protected fundamental rights of the people.

Wilson's modest statement can be contrasted with his analysis of the first big statutory case decided by the U.S. Supreme Court. In Chisholm $v$. Georgia, the Court held that Article 11I and the Judiciary Act of 1789 gave federal courts jurisdiction to entertain common law damages suits against the states. ${ }^{349}$ Attorney General Edmund Randolph, representing the claimants, relied on the letter of the Constitution and the statute. ${ }^{350}$ The Judiciary Act vested the Supreme Court with exclusive jurisdiction in civil cases "where a state is a party, except between a state and its citizens; and except also between a state and citizens of other states or aliens," where the Court would have original but not exclusive jurisdiction. ${ }^{351}$ Randolph argued that because neither the law nor the analogous constitutional provision distinguished between the state as a plaintiff and the state as a defendant, the Act constitutionally vested jurisdiction in federal courts against the states, and abrogated their common law immunities from suit. ${ }^{352}$

The Justices did not follow Randolph's literalist approach, but a majority agreed with his conclusions. Going well beyond the cautiously equitable views quoted above, Justice Wilson interpreted the statute and Article III in a broadly equitable way. "A cause so conspicuous and interesting, should be carefully and accurately viewed from every possible point of sight," including "principles of general jurisprudence," the practice of other countries, and the goals and spirit of the Constitution. ${ }^{353}$ The philosophy of "common sense" and popular sovereignty that animated the American Revolution and found ultimate refuge in the Constitution was, reasoned Wilson, deeply inconsistent with the old notions of sovereign immunity on which Georgia was relying. ${ }^{354}$ Only after establishing

348. 2 The Works of James Wilson 478 (Robert Green McCloskey ed., 1967).

349. 2 U.S. (2 Dall.) 419, 433-38 (1793).

350. 1d. at 419-29 (reporting Randolph's argument).

351. Judiciary Act of 1789, ch. 20, $\$ 14,1$ Stat. 73, 80-81 (1789).

352. See 2 U.S. (2 Dall.) at 426. Randolph also relied on the fact that the law clearly contemplated that states be defendants in at least one category of cases, namely, states suing other states. Further, he noted that there was no provision for executing judgments against states, but section 14 of the Act could accommodate that necessity, just as it apparently gave the Supreme Court authority to enforce judgments in state-versus-state lawsuits. See id. at 426-27.

353. Id. at 453 (Wilson, J.).

354. See id. at 453-54 (invoking Dr. Reid's philosophy of "common sense" as basis for rejecting traditional political categories), 455-56 (stating that Georgia's argument 
this baseline did Wilson examine the plan of the Constitution and, almost as an afterthought, the "direct and explicit declaration of the Constitution itself." ${ }^{555}$ The opinion of Chief Justice Jay, another Framer and the third author of the famous Federalist papers, was equally broad and philosophical. Jay followed Randolph in emphasizing the letter of the statute, ${ }^{356}$ but gave greater emphasis to the general plan of the framing, which necessarily stripped the states of any special privileges. "The exception contended for, would contradict and do violence to the great and leading principles of a free and equal national government, one of the great objects of which is, to ensure justice to all." ${ }^{57}$ Like Wilson's, Jay's reading of the statute was pervasively influenced by his understanding of Article III.

Only Justice Iredell (another key Framer who served as a Justice on the early Court) dissented from Randolph's reading of the Judiciary Act and Article III. He did not dispute that the words of the law seemed to include lawsuits against the states but instead focused on section 14's grant of power to issue writs necessary for the exercise of their jurisdiction, "and agreeable to the principles and usages of law."358 This language suggested (to lredell) the relevance of the common law, which assured states of immunity from suit, subject to a clear statement to the contrary by Congress. ${ }^{359}$ He was invoking an ameliorative power to narrow the words of a broadly phrased statute in light of the common law, and the end of his opinion invoked the voidance power, as he further opined that the Constitution did not authorize the abrogation of state immunity. ${ }^{360}$ Although his colleagues announced that the spirit as well as the letter of the Judiciary Act and the Constitution failed to recognize state immunity, lredell felt that his approach to both the Constitution and the Act was more faithful to their original expectations. ${ }^{361}$ As a prac-

"Invert[s] [the] course of things" against their "natural order"), 464-66 (asserting that "general texture" of the Constitution is inconsistent with retained state sovereignty).

355. Id. at 466.

356. See id. at 476-77 (Jay, C.J.) (reading the "words" of both Article III and $§ I 4$ to be "free from ambiguity").

357. Id. at 477; see id. at 479 (stating that "[ $t]$ he extension of the Judiciary power of the United States to such controversies, appears to me to be wise, because it is honest, and because it is useful.").

358. Judiciary Act of I789, ch. 20, § I4, I Stat. 73 (I789).

359. 2 U.S. (2 Dall.) at 433-36 (Iredell, J.). By this move, common law immunity became the baseline, and the inquiry was whether the Constitution or some other new development abrogated it; Justice Iredell believed it did not. See id. at 437-49.

360 . Id. at $449-50$.

36I. During the ratification debates, Brutus claimed that Article III by its words abrogated state immunity from suit, Brutus XIII, N.Y. J., Feb. 2I, I788, reprinted in 2 Bailyn's Debate, supra note 253, at 223, a charge that Publius denied, The Federalist No. 8I, at 487-88 (Alexander Hamilton) (Clinton Rossiter ed., I961); see also John Marshall, On the Fairness and Jurisdiction of the Federal Courts (June 20, 1788), reprinted in 2 Bailyn's Debate, supra note 253, at 734 (same). I do not have an opinion as to who was right in the Wilson-Iredell debate. There is an impressive modern scholarship on this issue. See, e.g., Akhil Reed Amar, Of Sovereignty and Federalism, 96 Yale L.J. 1425, 
tical matter, his position was the more tenable in the 1790s. Chisholm was denounced as repugnant to the principles of American governance; within four years the country overrode it with the Eleventh Amendment-an exercise of constitutional retraction not to be repeated until the Reconstruction amendments overrode Dred Scott.

The Chisholm opinions were a clear signal that the Federalist Justices intended to follow equitable constructions and to consider fundamental law in appropriate statutory cases, including those which could have easily been decided by simple application of the ordinary understanding of the letter of the law. In the next important case, Ware v. Hylton, the Court stretched the words of a treaty to carry out its goals and to establish an important national policy. ${ }^{362}$ In 1777 , Virginia enacted a law allowing people to discharge debts owed to British subjects by paying a sum to the state. ${ }^{363}$ The creditors in suit relied on Article IV of the Treaty of Peace entered between the United States and England in 1783. Article IV stipulated that "Creditors on either side shall meet with no lawful impediment to the recovery of the full value in sterling money, of all bona fide debts heretofore contracted." 364 The debtors, through their counsel John Marshall, responded that the treaty provision only applied in cases where a debt existed in 1783; they had been discharged from debt by the 1777 law. "The words [of the treaty] ought, surely, to be very plain, that shall work so evident a hardship, as to compel a man to pay a debt, which he had before extinguished." 365 Two Justices agreed with Marshall that Virginia had extinguished the debt, ${ }^{366}$ but the Court unanimously ruled that Article IV trumped state law anyway.

"The intention of the framers of the treaty, must be collected from a view of the whole instrument, and from the words made use of by them to express their intention, or from probable or rational conjectures," said Justice Samuel Chase. ${ }^{367}$ When the words are "clear and precise," no further evidence is needed. ${ }^{368}$ Chase responded to Marshall's argument that his clients' debts had been extinguished by 1783: "This adhering to the letter, is to destroy the plain meaning of the provision; because, if the treaty does not extend to debts paid into the state treasuries, or loan offices, it is

1467-92 (1987) (discussing early sovereign immunity jurisprudence); John J. Gibbons, The Eleventh Amendment and State Sovereign Immunity: A Reinterpretation, 83 Colum. L. Rev. 1889, 1920-39 (1983) (describing Chisholm and its aftermath).

362. 3 U.S. (3 Dall.) 158, 175-225 (1796) (seriatim).

363. Id. at 175 .

364. Definitive Treaty of Peace, Sept. 3, 1783, U.S.-U.K., art. IV, 18(2) Stat. 206, 207.

365. Ware, 3 U.S. (3 Dall.) at 213.

366. See id. at 233-35 (Chase, J.); id. at 270 (Iredell, J.). Justice Paterson disagreed with Chase and Iredell on this point, id. at 247 , and the other Justices assumed rather than ruled on the proposition. See id. at 281 (Wilson, J.); id. at 282 (Cushing, J.).

367. Id. at 239 (Chase, J.); cf. id. at 249 (Paterson, J.) (agreeing).

368. 1d. at 240 (Chase, J.). 
very clear that nothing was done by the treaty as to those debts . ..."369 This answer was confused and circular. Marshall's argument was that Article IV's words were not aimed at debts that had been extinguished before 1783; its non-evasion rule only reached state laws barring British creditors from the use of state courts to enforce existing debts or requiring the creditors to accept worthless paper currency in discharge of preexisting debts. ${ }^{370}$ Nor was Chase able to explain why the creditors should not have been required to sue the state itself, for Virginia had received money from the debtors and implicitly assumed whatever obligations the debts still carried with them. Chisholm was then good law, and the creditors could theoretically have gotten a judgment from the state. In the end, Chase's position, and the Court's, rested more on the broad remedial purpose of the treaty, to eradicate all state impediments to creditor expectations, than on any persuasive exposition of the treaty's words.

As in Hylton $v$. Ware, the Justices typically paid due regard to statutory words and often spoke of their primacy, ${ }^{371}$ but often failed to analyze the import of statutory language in any careful way. Consider Priestman $v$. United States. ${ }^{372}$ Section 19 of a federal coasting trade law required a federal permit for the transport of foreign goods from Maryland across the state of Delaware and into Pennsylvania. ${ }^{373}$ Section 19 further required the owner to swear that import duties had been paid and imposed a forfeiture penalty on the owner for failure to comply with the various permit requirements. ${ }^{374}$ William Priestman had imported watches into Baltimore and had paid duties on them. He shipped the watches to Pennsylvania without the permit required by the statute but objected that the provision did not apply to him because of section 33 near the end of the statute:

That in all cases where [the cargo] on board any ship [etc.] shall belong bona fide to any person or persons other than the master, owner, or mariners of such ship or vessel and upon which the duties shall have been previously paid or secured, according to law, shall be exempted from any forfeiture under this act, any thing therein contained to the contrary notwithstanding. ${ }^{375}$

The government responded that section 33 only related to the sections of the statute that were exclusively concerned with transport across water,

369. Id. at 243. The quotation in text suggests that the term plain meaning signified something different in the eighteenth century than it does today.

370. See id. at 213-14 (reporting Marshall's argnment).

37I. E.g., Bas v. Tingy, 4 U.S. (4 Dall.) 37, 37 (1800) (discussing the possible meanings of the word "enemy" in an Act of Congress).

372. 4 U.S. (4 Dall.) 28, 29 (1800) (per curiam) (summarily affirming the circuit court).

373. Act of Feb. 18, I793, ch. $8, \S 19,1$ Stat. 305, 313 .

374. Id.

375. $\S 33,1$ Stat. at $316 ; 4$ U.S. (4 Dall.) at 31 . 
which this was not (although Priestman had engaged vessels to transport his watches to Pennsylvania). ${ }^{376}$

As counsel had cited Plowden for the defense, Justice Chase's opinion for the circuit court commenced with a criticism of the English practice "distinguishing between the intent, and the words, of the legislature," whereby:

a case not within the meaning of a statute, according to the opinion of the Judges, shall not be embraced in the operation of the statute, although it is clearly within the words: or, vice versa, that a case within the meaning, though not within the words, shall be embraced. ${ }^{377}$

As he was "sitting in an American Court," Chase insisted he would follow the "letter of the statute, when free from ambiguity and doubt; without indulging a speculation, either upon the impolicy, or the hardship, of the law." 378 Chase then simply announced that section 19 applied to the case and section 33 did not. The Supreme Court affirmed, without the literalist rhetoric, but also without much more analysis of the statutory words. The Court held that Priestman fell within section 19, which needed to be "strictly executed" because "[p]ublic policy, national purposes, and the regular operations of government, require, that the revenue system should be faithfully observed." 379 The Court then ruled section 33 inapplicable because its object was different from that of section 19, but that sensible argument was rendered less clear by the Court's earlier statement. If the object of section 19 were to assure the collection of revenue (the Court's emphasis), the exception in section 33 for cases where the owner had paid all the import duties owed under the law does not seem so unfair. All the Justices paid attention to statutory words, but words that were not tightly drafted, as section 19 did not fit into the statutory scheme and section 33 was written with odd and probably unintended breadth. Moreover, all the Justices narrowed section 33, creating an exception for section 19 cases.

Priestman also suggests that Justice Chase was a more literalist rhetorician than most other Justices-unsurprising when one recalls that Chase had been a Brutus-like opponent of the Constitution. ${ }^{380}$ Following the Anti-Federalist approach to statutory interpretation, Chase emphasized a rudimentary version of what twentieth-century writers would call the plain meaning rule: If the text is plain, context cannot derogate from it. Contrast his approach with the more contextual one of Justice Wilson, quoted

376. $\$ 32,1$ Stat. at 316 (providing for forfeiture of vessel and cargo if vessel engages in trade for which it is not licensed, etc.); 4 U.S. (4 Dall.) at 32-33.

377. 4 U.S. (4 Dall.) at 30-31 n.1 (Chase, J.) (reproducing in full the detailed opinion of the circuit court).

378. Id.

379. Id. at 34 (per curiam).

380. But astounding in light of Chase's broad approach to constitutional interpretation in Calder v. Bull, 3 U.S. (3 Dall.) 386, 388 (1798), to which Iredell responded witl a cautious approach to constitutional construction, id. at 398-401. 
at the beginning of this Part, ${ }^{381}$ and of Chief Justice Ellsworth in Wiscart $v$. Dauchy:

The law may, indeed, be improper and inconvenient; but it is of more importance, for a judicial determination, to ascertain what the law is, than to speculate upon what it ought to be. If, however, the construction . . . would amount to a denial of justice, would be oppressively injurious to individuals, or would be productive of any general mischief, I should then be disposed to resort to any other rational exposition of the law, which would not be attended with these deprecated consequences. ${ }^{382}$

To similar effect were Justice Iredell's opinions in Chisholm and in Minge v. Gilmour. ${ }^{383}$ In the latter case, involving the assertedly retroactive application of a statute to affect property rights, Iredell set forth his understanding of the interpretive enterprise:

All courts, indeed, as being bound to give the most reasonable construction to acts of the legislature, will, in construing an act, do it as consistently with their notions of natural justice (if there appears any incompatibility) as the words and context will admit; it being most probable that, by such construction, the true design of the legislature will be pursued; but, if the words are too plain to admit of more than one construction, and the provisions are not inconsistent with any articles of the constitution, I am of opinion ... that no court has authority to say the act is void because in their opinion it is not agreeable to the principles of natural justice. ${ }^{384}$

These understandings by three of the most prominent supporters of the Constitution during the ratification period (Wilson, Ellsworth, Iredell) are reminiscent of Blackstone and Hamilton. Like Hamilton in The Federalist 78 and 81 , however, these jurists avoided the term "equitable" when they spoke of construction. This may have reflected Pickering's notion that law and equity were two sides of the same coin. It may have reflected normative questions that had been raised against such rhetoric during the ratification process-questions that continued to be pressed by their colleague Chase and perhaps by other lawyers in the 1790s. Although the Court did not share Chase's literalism, the other Justices were politically savy enough to avoid the unnecessary red flags that might be raised by opinions laced with equity talk. (The adverse political reaction to Chisholm, and especially Wilson's rhetorically high-flying opinion, may have contributed to this process.).

381. See supra note 348 and accompanying text.

382. 3 U.S. (3 Dall.) 321, 328-29 (1796); see supra text accompanying note 167 (explaining that Ellsworth as a superior court judge in the 1780 s frequently engaged in equitable interpretation). But elsewhere Ellsworth said, "Suggestions of policy and conveniency cannot be considered in the judicial determination of a question of right." Moodie v. The Ship Phoebe Anne, 3 U.S. (3 Dall.) 319, 319 (1796).

383. 17 Cas. 440 (C.C.D.N.C. 1798) (No. 9631).

384. Id. at 444. Iredell ruled the statute constitutional and, finding it most consistent with principles of natural justice, gave it a retroactive effect. 
Justice Iredell's opinions in Minge and Chisholm call forth the most significant change I found between the state cases of the 1780s and early 1790s, and the federal cases of the 1790s. Although the Supreme Court did not flatly invalidate any federal statute before 1803, the Justices applied statutes to fit their understanding of constitutional principles and limits, and sometimes rewrote statutes in the process. As it waned in England, the voidance power waxed in America. Its earliest invocation by Supreme Court Justices was the opinion of Chief Justice Jay, Justice Cushing, and Judge Duane ${ }^{385}$ for the New York Circuit regarding their appointment to adjudicate pension claims, subject to administrative and then legislative review. ${ }^{386}$ The bench opined that the Constitution's separation of powers would not allow Congress to require the judicial branch to adjudicate cases under those circumstances but interpreted the law to appoint the three judges as "commissioners," carrying out the executive duties outside their official capacities as judges. ${ }^{387}$ This was a highly normative reading of the statutory words, but a reading which reflected the judges' insistence on separating their office from politics and administration.

A few other like cases followed. The issue in Mossman $v$. Higginson was whether the federal courts could entertain a lawsuit between two aliens. ${ }^{388}$ The Judiciary Act gave circuit courts jurisdiction in cases "where an alien is a party." 389 The Court rejected a broad-and arguably the most natural-reading of the law and narrowed it to cases "between citizens and foreigners," because that was all that Article III, Section 2 authorized. $^{390}$ In Vanhorne's Lessee v. Dorrance, Pennsylvania claimants relied on a state law allegedly divesting Connecticut settlers of their rights to disputed property. ${ }^{391}$ Finding the law inconsistent with the state constitution, Justice Paterson (on circuit) refused to apply it on the ground that it was void-applying the dictum in Bonham's Case to cases where a state statute and its constitution clash. ${ }^{392}$ As an alternative basis for his holding, Paterson then ruled that if the law were assumed to be valid, it

385. Judge Duane was the same jurist who decided Rutgers as well as a major speaker for ratification at the New York Convention.

386. See Hayburn's Case, 2 U.S. (2 Dall.) 409, 410 n. $\ddagger$ (1792) (quoting opinion of Apr. 5, 1791 by the Circuit Court of New York).

387. 1d. The Circuit Court for Pennsylvania refused to participate in the unconstitutional scheme, id. at 411-12 (quoting Letter from Members of the Circuit Court, District of Pennsylvania to Supreme Court and President of United States (Apr. 18, 1792)), and the Circuit Court for the District of North Carolina participated only in part, id. at 412-14 (quoting Letter from Members of the Circuit Court, District of North Carolina to Supreme Court and President of United States (June 8, 1792)). Congress changed the law the next year. See Act of Feb. 28, 1793, ch. 11, 1 Stat. 324.

388. 4 U.S. (4 Dall.) 12, 13-14 (1800) (per curiam).

389. Id. at 14 .

390. Id. For another example of the Court's reading statutes to reflect constitutional limits, see Hepburn v. Ellzey, 6 U.S. (2 Cranch) 445, 448 (1805) (Marshall, C.J.).

391. 2 U.S. (2 Dall.) 304, 306 (C.C.D. Pa. 1795).

392. See id. at 308 (clearly referring to Bonham's Case but not naming it). 
must be interpreted narrowly to avoid clashing with common law property rights. ${ }^{393}$ Because a raw transfer of land from one party to another by the legislature would be "extraordinary," the court ruled that it should be "viewed with jealous eyes, examined with critical exactness, and scrutinized with all the severity of legal exposition. An act of this sort deserves no favor; to construe it liberally would be sinning against the rights of private property." 394 The court ruled that implicit conditions of the statute had not been fulfilled and therefore that the statute did not apply. "This construction corresponds with the meaning and spirit, the tendency and scope, of the act itself." 395

Vanhorne's Lessee and the other voidance power cases not only reflected the Justices' pragmatic willingness to bend the words of the law in light of the larger legal landscape, but also their willingness to ameliorate the application of federal statutes when the reach of their broad language would be unfair or unnecessary for legitimate legislative objects. Nowhere was the courts' ameliorative power more pronounced than in admiralty cases, a big portion of the early federal caseload. ${ }^{396}$ Many of the cases were adjudicated by South Carolina District Judge Bee, in whose hands equity smoothed the rough edges of the law. For example, in Bray v. The Atalanta, a seamen's wage case, Judge Bee interpreted both the seamen's contracts and a 1792 statute equitably, forgiving most of the men for leaving an unseaworthy ship and giving them partial but not full wages. ${ }^{397}$ On other occasions, Judge Bee was willing to supplement statutory law, incrementally. The seaman's wage law did not say anything about forfeiture of wages for insubordination, but in Drysdale $v$. The Ranger, Bee drew from English maritime law the principle that under some circumstances disobedience to the captain's orders can justify withholding some or all the seaman's wages. ${ }^{398}$ ln the case before him, where

393. "Every statute, derogatory to the rights of property, or that takes away the estate of a citizen, ought to be construed strictly." Id. at 316; see Bacon, supra note 38, at 647 (setting forth a similar maxim).

394. Vanhome's Lessee, 2 U.S. (2 Dall.) at 318.

395. Id.

396. One would expect decisions interpreting admiralty statutes to invoke nontextual considerations more often than other kinds of statutes, because maritime law enjoyed a tradition of equitable principles. See The Ship Virgin v. Vyfhius, 33 U.S. 538, 550 (1834); Oliver v. Alexander, 31 U.S. 143, 146 (1832); Brown v. Lull, 4 F. Cas. 407, 410 (C.C.D. Mass. 1836) (No. 2018). For English authorities, see The Juliana, 165 Eng. Rep. 1560, 1567 (Adm. 1822); The Fortitudo, 165 Eng. Rep. 1415, 1419 (Adm. 1815); Buck v. Rawlinson, 1 Eng. Rep. 470, 470 (P.C. 1704).

397. 4 F. Cas. 37 (D.S.C. 1794) (No. 1819). In construing the contract, Judge Bee found "a state of things not contemplated at the signing of these articles," which "must be taken into consideration by every court acting upon equitable principles." 1d. at 38 . Although not authorized by the statute, Judge Bee insisted that the seamen have restitution for work actually performed. See id. (relying on English maritime law to soften the statute); see also Coleman v. The Harriet, 6 F. Cas. 62, 62 (D.S.C. 1796) (No. 2982) (awarding only a portion of the extra pay statute provided for as remedy for lack of provisions, because it was "sufficient compensation for the deficiency").

398. 7 F. Cas. 1118, 1118 (D.S.C. 1799) (No. 4097). 
a seaman called the captain a fool and suffered blows, Judge Bee concluded: "If, indeed, resistance had been made, and this [sea]man's hand lifted against his captain, I should have decreed a forfeiture of wages without hesitation. As the seaman's life is a hard one, and as the actor did his duty faithfully for a long time, with this only exception, 1 shall order and adjudge that his wages be paid." 399

Federal judges in the 1790s were not as willing to supplement criminal statutes, ${ }^{400}$ but 1 was surprised by their reluctance to ameliorate their harsh operation either. Decisions showing criminal defendants lenity in the 1790 s typically involved procedural rather than substantive rights. ${ }^{401}$ For political reasons, the federal judges accommodated prosecutors' needs, construed criminal laws broadly, and procured convictions in almost all the reported cases. Some of the cases involved the Seditious $\mathrm{Li}$ bel Act of 1798, ${ }^{402}$ adopted by Congress to silence critics of the Adams administration. Although the statute liberalized the common law by making truth a defense, it was applied to chill First Amendment political speech. While some states protested the legality of these prosecutions, the federal judges presiding over the trials showed not an ounce of lenity. ${ }^{403}$ Other cases involved prosecutions for treason following the 1794 insurgency in the western counties of Pennsylvania. In his notorious jury charge in the retrial of In re Fries, Justice Chase ruled that Congress could not change the Constitution's definition of treason ("levying War against [the United States] or in adhering to their Enemies") but then interpreted the Constitution broadly, to include riots protesting government taxes and to make every accessory to the riot a principal subject to the

399. Id. at 1119.

400. For example, federal judges debated whether the Constitution required a statutory basis for the prosecution of federal crimes. Compare United States v. Worrall, 2 U.S. (2 Dall.) 384, 388-93 (C.C.D. Pa. 1798) (Chase, J.) (requiring specific statutory authorization), with id. at 393-96 (Peters, J.) (finding common law federal crimes implicit in section 11 of the Judiciary Act).

401. See United States v. Fries, 9 F. Cas. 826, 921-22 (C.C.D. Pa. 1799) (No. 5,126) (ruling that court has the power to grant new trials in criminal cases only for the benefit of the accused and not for the government); United States v. Insurgents, $26 \mathrm{~F}$. Cas. 499, 514 (C.C.D. Pa. 1799) (No. 15,443) (rejecting most of defendants' procedural claims but insisting that prosecution provide more detailed addresses for juror and witness lists, in light of the purpose of the rule); United States v. Stewart, 2 U.S. (2 Dall.) 343, 344 (C.C.D. Pa. 1795) (liberally interpreting same law, requiring lots of time for defendants to conduct their investigations, even though this would require the cases to be put over to the next term).

402. Act of July 14, 1798, 1 Stat. 596 (1798).

403. See United States v. Haswell, 26 F. Cas. 218, 219 (C.C.D. Vt. 1800) (No. 15,324) (finding that even though truth was a defense, a defendant must still show a justification for the charge); Lyon's Case, 15 F. Cas. 1183, 1185 (C.C.D. Vt. 1798) (No. 8,646) (charging jury to try defendant without consideration as to the constitutionality of the statute). 
death penalty. ${ }^{40,4}$ : Chase's aggressive charge in Fries, where a man's life was at stake, was a nasty contrast to his pious literalism in Priestman. ${ }^{405}$

\section{B. The Early Marshall Court, 1801-07}

The Supreme Court's second decade occurred in circumstances hardly imaginable to the Constitution's Framers, as party politics replaced consensus and threatened the independence of the federal judiciary. John Marshall's appointment as Chief Justice came in the late hours of the Adams administration. Having lost the election of 1800, the Federalists sought to pack the bench, which stimulated a Republican attack on the judiciary that almost doomed its independence. The Jefferson Administration procured legislation abolishing the new federal judgeships created by the Federalists after the election and canceling the June 1802 Term of the Supreme Court. The House voted to impeach senile Judge John Pickering and the arrogant Justice Chase, and the Senate voted to remove Pickering. ${ }^{406}$ Marshall himself was saved from impeachment by the Senate acquittal of Chase, but his Court got started under siege-like circumstances. The Court not only survived but prospered, and Marshall's brilliant deployment of statutory analysis was part of his phenomenal success story. ${ }^{407}$

At the Court's lowest point, following the lost June 1802 Term and a week before the Court issued its decision acquiescing in the Republicans' abolition of existing judicial offices, ${ }^{408}$ Marshall delivered his opinion in Marbury v. Madison. ${ }^{409}$ Marbury invoked the Supreme Court's original jurisdiction to sue Secretary of State Madison for mandamus requiring him to deliver his judicial commission. Marshall's opinion denying relief was oddly structured, deciding the merits and then determining that the statute giving the Supreme Court original jurisdiction in the case was un-

404. See 9 F. Cas. 924, 930-32 (C.C.D. Pa. 1799) (No. 5,127) (reading the British idea of "constructive treason" into the Constitution and statute). After Fries was convicted, Chase lectured the defendant about how the government had shown lenity in prosecuting only a fraction of the insurgents for the capital crime of treason. See id. at 933-34.

405. See supra note 378 and accompanying text.

406. The best account of the Republican purge remains 3 Albert J. Beveridge, The Life of John Marshall: Conflict and Construction, 1800-1815, at 50-100, 157-222 (1919); see also George L. Haskins \& Herbert A. Johnson, Foundations of Power: John Marshall, 1801-1815, at 13, 141-42, 151-81, 205-45 (1981) (The Oliver Wendell Holmes Devise History of the Supreme Court of the United States vol. II).

407. On Marshall generally, see the thorough but hagiographic treatment in Albert J. Beveridge, The Life of John Marshall (1919) (4 volumes), as well as Charles F. Hobson, The Great Chief Justice: John Marshall and the Rule of Law (1996); William E. Nelson, The Eighteenth Century Background of John Marshall's Constitutional Jurisprudence, 76 Mich. L. Rev. 893 (1978). On Marshall's Court, see Haskins \& Johnson, supra note 406; G. Edward White, The Marshall Court and Cultural Change, 1815-1835 (1988) (The Oliver Wendell Holmes Devise History of the Supreme Court of the United States vol. III \& IV) [hereinafter White, Marshall Court].

408. See Stuart v. Laird, 5 U.S. (1 Cranch) 299, 309 (1803).

409. 5 U.S. (1 Cranch) 137 (1803). 
constitutional, but this structure allowed him to announce the Court as guarantor of a nonpartisan rule of law that limited all three branches of government: The executive branch had discretion in political matters but not matters of vested legal right, the legislature could not validly enact laws inconsistent with the Constitution, and the judiciary was limited to the heads of jurisdiction in Article III and to issues of right and not issues of policy. ${ }^{410}$ Ironically, Marshall's ode to the rule of law was accomplished in the teeth of the statute he invalidated. Section I3 of the Judiciary Act, defining the jurisdiction of the Supreme Court, had four sentences: Sentences one and two gave the Court original jurisdiction over specified cases; sentence three assured that trials of any issue of fact, presumably in original jurisdiction cases where the Court would be the trier of fact, would be by jury; sentence four provided that the Court should have appellate jurisdiction in specified cases and "shall have power to issue writs of prohibition to district courts [in admiralty cases] ... and writs of mandamus, in cases warranted by the principles and usages of law, to any courts appointed, or persons holding office, under the authority of the United States." 411 Like Marbury, Marshall treated the mandamus clause as vesting original jurisdiction in the Court to consider the claim against Madison, who was "precisely within the letter of the [statutory] description." 412 That was not the case at all. Sentences one and two gave the Court no basis for original jurisdiction, and sentence four's mandamus clause was part and in aid of the Court's appellate jurisdiction. ${ }^{413}$ By no reasonable reading of the statute's words was the Court given original jurisdiction just because the petitioner was suing in mandamus.

Although Marbury is the most counter-textual opinion examined in this Article, its statutory sleight of hand was not a result of carelessness or inability, for the author was the most astute statutory analyst of the founding and consolidating periods. ${ }^{414}$ Chief Justice Marshall was a master at

410. See William W. Van Alstyne, A Critical Guide to Marbury v. Madison, 1969 Duke L.J. 1 passim (providing critical in-depth analysis of the opinion in its context); see also Robert Lowry Clinton, Marbury v. Madison and Judicial Review 81-101 (1989) (same).

411. Judiciary Act of 1789, 1 Stat. 73, 80-81 (1788) (footnotes omitted).

412. Marbury, 5 U.S. (1 Cranch) at 173.

413. See Thomas R. Haggard, Marbury v. Madison: A Concurring/Dissenting Opinion, 10 J. L. \& Pol. 543, 550-52 (1994). Mandamus could be an instrument of either appellate or trial court authority, but writs of prohibition-the object of the other clause in sentence four, right before the mandamus clause-were only issued in connection with appeals. It may be that mandamus was mentioned only in sentence four because it was a routine power of a trial court but a more exceptional power of an appeals court. For somewhat different argumentation for the proposition that Marshall misconstrued section 13, see Akhil Reed Amar, Marbury, Section 13, and the Original Jurisdiction of the Supreme Court, 56 U. Chi. L. Rev. 443, 456-63 (1989).

414. Marbury was not the only big constitutional case where Marshall's strategy included an unpersuasively broad statutory construction. See also Worcester v. Georgia, 31 U.S. (6 Pet.) 515, 561-62 (1832) (broadly construing federal laws and treaties regarding Native Americans); Gibbons v. Ogden, 22 U.S. (9 Wheat.) 1, 210-14 (1824) (broadly 
arguing from statutory text and structure, and at fitting the arguments into a coherent substantive vision, as he had shown in Bracken and Hylton (and dozens of other appellate cases he argued in the 1790s). His overall project was to position the Court as the guarantor of a federal rule of law-creating predictable, fair, and nationally integrated rules of conduct from federal statutes, treaties, and constitutional rules. To accomplish that end, Marshall polished a methodology that merged logos and equity: The words of the law adopted by the legislature would be vigorously applied, but would be read in light of the policy choices made by the legislature and in light of the fundamental law of the Constitution, the law of nations, and the common law. 415 Thus, Marshall was neither a literalist like Justice Chase nor an equity judge like Justice Washington. His opinions transcended the logos/equity debate of the 1780s and 1790s.

Three of Marshall's other early opinions illustrate my thesis. One of his first cases, Talbot v. Seeman, involved a 1799 re-capture by Americans of the Amelia, a ship from Hamburg that had been captured by the French, who were then engaged in partial hostilities with the United States (but not with Hamburg). ${ }^{416}$ The American captain requested an award of salvage amounting to half the value of the ship. The issues on appeal were whether the re-capture was lawful and, if so, what salvage amount was proper. Six federal statutes related to capture and salvage; none authorized an American ship to re-capture a neutral vessel that had been highjacked by the French or any hostile power. ${ }^{417}$ Three statutes adopted in 1798 authorized the re-capture of vessels belonging to citizens of the United States; a fourth authorized the capture of "any armed French vessel found on the high seas." 418 Marshall conceded that the recaptured vessel was neither owned by U.S. citizens nor accurately characterized as a "French vessel." 419 Yet he filled in the statutory gap, ruling the Amelia's re-capture lawful, based on the "universal principle . . . that where there is probable cause to believe the vessel met with at sea, is in the condition of one liable to capture," that is, one might reasonably have believed the Amelia was a French vessel (even though it was not), "it is lawful to take her, and subject her to the examination and adjudication

construing federal licensing statute, to assure preemption of state law); Osborn v. Bank of the United States, 22 U.S. (9 Wheat.) 738, 817-18 (1824) (employing a broad reading of the Bank's sue-or-be-sued clause to vest jurisdiction in federal circuit courts for lawsuits brought by the Bank).

415. For detailed exegesis of this methodology in the Indian law context (cases decided after 1807), see Philip P. Frickey, Marshalling Past and Present: Colonialism, Constitutionalism, and Interpretation in Federal Indian Law, 107 Harv. L. Rev. 381, 406-I7 (I993)

416. 5 U.S. (1 Cranch.) 1, 1 (1801).

4I7. See id. at 29-31 (quoting the six statutes and concluding that none authorized re-capture by its plain words).

418. Id. at 30 .

419. Id. at 31 . 
of the courts." 420 Could a right of salvage emerge from such a mistake? Marshall thought so, for "it would probably have been a great departure from the real intent of congress, to have permitted such vessel to cruise unmolested." To say that an actual French vessel, armed and capable of attacking American ships, could be seized (as the statutes explicitly authorized), but not a vessel the French had commandeered to equal bad effect, "would be to attribute a capriciousness to our legislation on the subject of war, which can only be proper when inevitable."421 Marshall did not use the term equity of the statute, but refusing to attribute capriciousness to the legislature played the same role; there is no better example of that concept than his analysis of the re-capture issue in Talbot $v$. Seeman. ${ }^{422}$ Nor is there any clearer example of a judge's reworking of statutory language to fit with broader principles of the law.

No clearer example, but for the Chief Justice's treatment of the amount of salvage issue in the same case. The Act of March 2, 1799, authorized salvage of one-half for vessels owned by citizens of friendly countries that were re-captured after more than four days "in the possession of the enemy." 423 The American captain stoutly maintained that his re-capture "is in the very words of the act," which Marshall conceded.424 But the Amelia's owners made a counterargument that Marshall liked better:

[1]t has been urged, and we think with great force, that the laws of the United States ought not, if it be avoidable, so to be construed as to infract the common principles and usages of nations, or the general doctrines of national law. If the construction contended for be given to the act, it subjects to the same

420. Id. at $31-32$.

421. Id. at 32-33.

422. Marshall wrote:

The court goes no further than to use the provisions in one of several acts forming a general system, as explanatory of other parts of the same system; and this appears to be in obedience to the best established rules of exposition, and to be a necessary to a sound construction of the law.

Id. at 35. Marshall also pointed out that an Act of June 28, 1798 authorized re-capture of vessels whose captures had not been expressly regulated. This suggested to him that the various statutes did not comprehensively regulate the area and left room for application of "the principles of general law." Id. at 34. The state of war between the United States and France was sufficient to trigger the re-capture rights in this kind of case. Finally, Marshall invoked the Act of March 3, 1800, adopted well after the Amelia's capture and re-capture, to illustrate his proposition that a right of salvage could exist for re-capture not authorized in the earlier statutes. 1d. at 34-35.

423. Id. at 30. The Act of March 2, 1799, suggests a text-based reason that could have supported the first holding of Seeman: Because Congress was assuming in the latter statute that re-capture was authorized for vessels owned by neutrals but captured by a hostile country (France), the badly drafted earlier statutes should be construed to include this arguably inadvertent omission. See id. at 29-30.

424. 1d. at 43. That is, the Americans' re-capture of the Amelia was of a vessel "belonging to . . . citizens or subjects of any nation in amity with the United States," which had been held for more than four days "in possession of the enemy," France. Id. at 30. 
rate of salvage a re-captured neutral, and a re-captured belligerent vessel. Yet, according to the law of nations, a neutral is generally to be restored without salvage. ${ }^{425}$

Based on this idea, Marshall announced that the 1799 statute should be limited to those cases where the prize seizure was by an "enemy . . of both parties," both the United States and Hamburg. ${ }^{426}$ That not being the case, Marshall ruled the statute inapplicable. He observed, "[b]y this construction the act of congress will never violate those principles which we believe, and which it is our duty to believe, the legislature of the United States will always hold sacred." 427 Based upon the maritime law of nations, the Chief Justice deemed one-sixth salvage to be a "reasonable allowance" for the Americans. ${ }^{428}$ So in one case Chief Justice Marshall extended the words of re-capture statutes to cover a casus omissus (suppletive power, or equity of the statute), while also narrowing the words of a salvage-value law (ameliorative power). But he did so by enriching rather than disrespecting the words Congress had chosen to regulate these matters.

A second Marshall decision, United States v. Schooner Peggy, provides context for a deeper reading of Seeman. ${ }^{429}$ The Schooner Peggy was an armed French vessel captured by an enterprising American captain; the 1798 statutes discussed in connection with Seeman authorized the capture and promised the captor half the value of the ship as salvage. The issue in Schooner Peggy arose out of a treaty entered in 1800 that settled the informal war between the United States and France. Article IV of the treaty provided that "property captured, and not yet definitively condemned . . . shall be mutually restored." The American captain had already obtained a court order condemning the Schooner Peggy, and the order had been executed on the vessel, so that it was within the possession of the American. Notwithstanding these facts, Chief Justice Marshall ruled that the vessel had not been "definitively condemned," because the order was on appeal and therefore could have been reversed at the time the treaty took effect. ${ }^{430}$ This was an odd interpretation of the treaty's words and seemed to suggest that all captures effected during the informal war were susceptible to return. Professor Mark Graber persuasively maintains that Marshall knew that his broad interpretation was flatly contrary to the intended construction of the treaty but adopted it anyway to avoid a conflict with the Jefferson administration and to signal that his Court was prepared to cooperate in the Administration's efforts to nor-

425. Id. at 43 .

426. Id. at 44. The language quoted in text is not a quotation from the statute, which just says "enemy," certainly of the United States. The quoted language is the statute as Marshall rewrote it.

427. Id. (emphasis added).

428. Id.

429. 5 U.S. (1 Cranch) 103 (1803).

430. Id. at 109 . 
malize relations with France. ${ }^{431}$ Graber's idea also helps explain the Chief Justice's stingy approach to salvage in Seeman, which would have been an early signal to the Jefferson Administration that the Court would go along with the new tilt in favor of France. ${ }^{432} 1$ t also illuminates Marbury: Marshall's approach to statutory interpretation was highly strategic; the Chief Justice was willing to bend words into any shape that would allow him to avoid damage to the fledgling institution of the Court.

Schooner Peggy was also strategic in another way. Marshall was surely aware that he was giving the words of the treaty a very broad construction, in a case where they could easily have been construed more narrowly (to require return of vessels where there had been no final adjudication or, perhaps, where the final judgment had not been executed). His remarkable opinion justified the broad rather than narrow reading of the words in an openly normative way that gave the citizenry libertarian assurances:

1t is true that in mere private cases between individuals, a court will and ought to struggle hard against a construction which will, by a retrospective operation, affect the rights of parties, but in great national concerns where individual rights, acquired by war, are sacrificed for national purposes, the [treaty], making the sacrifice, ought always to receive a construction conforming to its manifest import; and if the nation has given up the vested rights of its citizens, it is not for the court, but for the government, to consider whether it be a case proper for compensation. ${ }^{433}$

As he would later accomplish in Marbury, Chief Justice Marshall delivered an opinion whose holding was motivated by short-term political considerations but whose dicta reflected a longer-term project. That project had two prongs, both reflected in the previous quotation. On the one hand, Marshall was announcing fundamental principles of law that would, in less sensational cases, protect the vested property rights of citizens. On the other hand, he was also announcing a potentially ambitious basis for extensive national power, namely, the need to deal with foreign crises in ways that sacrificed traditional notions of contract and property. The next case 1 shall examine is an even better example of this Marshallian vision for public law.

The issue in United States $v$. Fisher was whether a 1797 statute made the United States a super-preferred creditor, whose claims were to be sat-

431. See Mark Graber, Establishing Judicial Review? Schooner Peggy and the Early Marshall Court, 51 Pol. Res. Q. 221, 228-31 (1998). Graber also points out that the Jefferson Administration was not pleased with the general rule adopted in Schooner Peggy, just as it would later disrespect the idea of judicial review announced in Marbury. See id. at 229, 232-35.

432. See Jean Edward Smith, John Marshall: Defender of a Nation 291-95 (1996) (ascribing strategic behavior to Marshall's willingness to reduce the salvage award in Seeman).

433. Schooner Peggy, 5 U.S. (1 Cranch) at 110. 
isfied ahead of all others. ${ }^{434}$ The act concerned "settlements of accounts between the United States, and receivers of public money," and the first four sections dealt only with such receivers. ${ }^{435}$ The fifth section said that "where any revenue officer, or other person[,] hereafter becoming indebted to the United States . . . shall become insolvent, ... the debt due to the United States shall be first satisfied." 436 Commercial assignees objected to the government's claim for preference, on the ground that the reference "revenue officer, or other person" should have been limited by the ambit of the rest of the statute to "receivers of public money." (The bankrupt was not a receiver of public moneys.). Because of its clear language, pointedly omitting the creditors' argued qualification, the Court found the fifth section severable from the first four and imposed the burden on the creditors to show a clear legislative intent to read the fifth section as narrowly as those four. ${ }^{437}$

In that context, Marshall considered the creditors' argument that the government's reading would result in "mischiefs":

That the consequences are to be considered in expounding laws, where the intent is doubtful, is a principle not to be controverted; but it is also true that it is a principle which must be applied with caution, and which has a degree of influence dependent on the nature of the case to which it is applied. Where rights are infringed, where fundamental principles are overthrown, where the general system of the laws is departed from, the legislative intention must be expressed with irresistable clearness to induce a court of justice to suppose a design to effect such objects.-But where only a political regulation is made, which is inconvenient, if the intention of the legislature be expressed in terms which are sufficiently intelligible to leave no doubt in the mind when the words are taken in their ordinary sense, it would be going a great way to say that a constrained interpretation must be put upon them, to avoid an inconvenience which ought to have been contemplated in the legislature when the act was passed . . . 438

As he had done in Schooner Peggy, Marshall took this opportunity to present the privilege he was creating for the national government in a cautious light. The statute did not void recognized liens or vested property

434. 6 U.S. (2 Cranch) 358, 358 (1805).

435. Act of Mar. 3, 1797, 1 Stat. 512.

436. $\S 5,1$ Stat. at 515. The bracketed comma is part of the text in Marshall's opinion, Fisher, 6 U.S. (2 Cranch) at 385 , but not part of the law as reported in 1 Stat. at 515. The law as punctuated in Marshall's opinion is a little more ambiguous than that in the Statutes at Large, for in the former the "hereafter becoming indebted to the United States" can more easily be read as primarily modifying "revenue officer," with "other person" as an afterthought (as it is in $\S 1$ of the law, 1 Stat. at 512).

437. See Fisher, 6 U.S. (2 Cranch) at 388-97, sharply contested in a separate statement by Justice Washington, who had authored the circuit court decision being reversed, id. at 397-405 (Washington, J., dissenting).

438. 1d. at 389-90. 
rights-a move that would presumably require a cléarer statement from Congress-but only created a payment preference, a matter wholly within the legislative discretion. He also turned the argument around, concluding his opinion with a survey of the hodgepodge of provisions in other federal statutes, including an ambiguous provision in the bankruptcy law adopted in $1799 .{ }^{439}$ The analytical point of the survey was to show that the provisions did not dislodge the plain meaning of the 1797 law, but the policy point was more potent. By construing the 1797 law with the breadth suggested by its encompassing language, the Court was making sure Congress did what it failed to do in 1799 and earlier-create an easyto-apply bankruptcy preference rule that would protect the public fisc. Even more powerful was the assumed, hidden constitutional point: Pursuant to its bankruptcy powers explicitly given in Article 1, Section 8 and the "implied" powers under the Necessary and Proper Clause, Congress had significant authority to displace state law and even to prefer its own interests over those of private creditors. ${ }^{440}$

Seeman, Schooner Peggy, and Fisher illustrate how Marshall from the beginning of his tenure as Chief Justice expansively applied federal statutes, under a text-based analysis that had room for broader considerations of equity and principle. ${ }^{441}$ In other cases, Marshall and other federal judges narrowed statutes even while reaffirming both the rule of law and expansive federal power. The statute in Willing $v$. United States provided that "when" any federally registered ship was sold to American citizens, the new owners were required to register the ship "anew" and were not entitled to the "privileges or benefits" of American registry if the ship had not been "registered anew." 442 The American defendants had bought the ship while at sea and had been assessed full duties upon arrival in the United States, because they did not-could not-register the ship until after their return. They argued that the statutory obligation was satisfied if they registered soon after arrival. District Judge Peters told the defendants they had the better rule, but the government had the law. "In the department in which I am placed, I am not competent to give relief; or by interpretations of supposed spirit and intention, supply omis-

439. See id. at 391-95.

440. See id. at 396 (directly anticipating McCulloch v. Maryland, 17 U.S. (4 Wheat) 316, 420-21 (1819)).

441. In Adams v. Woods, 6 U.S. (2 Cranch) 336 (1805), Marshall expanded a statutory limitations period for criminal prosecutions to cover qui tam actions, partly because the criminal prosecutions law used broad language, see id. at 340-41, and (more cogently) because "to declare that the [criminal] information was barred while the action of debt was left without limitation, would be to attribute a capriciousness on this subject to the legislature, which could not be accounted for." Id. at 341; see also Huidekoper's Lessee v. Douglass, 4 U.S. (4 Dall.) 391, 395 (1805) (Marshall, C.J.) (rewriting an incoherently drafted statute to make sense of it); Schooner Paulina's Cargo v. United States, 11 U.S. (7 Cranch) 34, 42-43 (1812) (Marshall, C.J.) (editing a sentence in a forfeiture law to remove "confusion").

442. 4 U.S. (4 Dall.) 374, 376 (C.C.D. Pa. 1804), aff'd sub nom. United States v. Willings \& Francis, 8 U.S. (4 Cranch) 48 (1807). 
sions, or add to the provisions of the then existing law." 443 The judge was partly consoled that Congress in 1803 had created a mechanism authorizing the Secretary of the Treasury to refund duties unfairly paid by owners under this and other maritime registry laws. Although Peters's literalist reading of the statute seems simple-minded, his sentiment was not isolated. Federal judges wanted to avoid the appearance of judicial legislation. "That a law is in itself inequitable . . . will not justify the court in dispensing with it. This would be to usurp the legislative power." 444

Notwithstanding this concern, the circuit court reversed. Justice Washington objected that the law, as the trial court construed it, required either an impossibility or arbitrarily prohibited such transfers while at sea. He refused to impute such a reading to the legislature. "There is no part of our navigation system, that expressly avows this to be the intention of the legislature; and from what principle of public policy can it be inferred, or presumed?" 445 Washington's circuit court opinions typically settled on constructions that were most "consistent with the acknowledged spirit of the law" and avoided practical "difficulties." 446 Nor was he idiosyncratic. When they construed statutes, federal judges not only weighed the words of the statute but also followed Washington in considering "inconveniences" and "well established principles," 447 as well as the "mischiefs" statutes were intended to address. ${ }^{448}$

The Peters/Washington debate recalled the law/equity debate during the founding period-a debate which the Chief Justice was eager to

443. See id. at $380 \mathrm{n} .1$ (reproducing district court opinion).

444. Wilson v. Wilson, 30 F. Cas. 248, 249 (C.C.D.C. 1805) (No. 17,848) (Kilty, G.J.); see also Evans v. Jordan, 8 F. Cas. 872, 873 (C.C.D. Va. 1813) (No. 4,564) (Marshall, Circuit Justice), aff d, 13 U.S. (9 Cranch) 199 (1815) (stating that interpretation "is never to be carried so far as to thwart ... [ [the] policy which the legislature has [adopted]"); The Adventure, 1 F. Cas. 202, 204 (C.C.D. Va. 1812) (No. 93) (Marshall, Circuit Justice) (explaining that rule of lenity is not meant to "overrule[ ]" legislature, but to avoid "extend[ing] the law to cases to which the legislature had not extended it").

445. Willing, 4 U.S. (4 Dall.) at 385.

446. Huidekoper v. Burrus, 12 F. Cas. 840, 842-43 (C.C.D. Pa. 1804) (No. 6,848) (Washington, Circuit Justice); see also United States v. Fisher, 25 F. Cas. 1087, 1089 (C.C.D. Pa. 1803) (No. 15,103) (Washington, Circuit Justice), rev'd, 6 U.S. (2 Cranch) 358 (1805); Anonymous, 1 F. Cas. 1032, 1035 (C.C.D. Pa. 1804) (No. 475) (Washington, Circuit Justice).

447. Bowerbank v. Morris, 3 F. Cas. 1062, 1064 (C.C.D. Pa. 1801) (No. 1,726) (Tilghman, C.J.); see United States v. Hammond, 26 F. Cas. 96,97 (C.C.D.C. 1801) (No. 15,293) (Cranch, Circuit Judge, joined by Marshall, Circuit Judge) ("No repugnancy or absurdity shall be presumed, especially in a statute, if the words will bear such a construction as to avoid it."). Washington and the other judges were perfectly willing to apply statutory plain meanings and could analyze complicated texts. E.g., Balfour's Lessee v. Meade, 2 F. Cas. 543, 546 (C.C.D. Pa. 1803) (No. 808) (Washington, Circuit Judge) (invoking the "plain meaning" of a complex settlement statute).

448. E.g., McCall v. Eve, 15 F. Cas. 1232, 1232 (C.C.D.D.C. 1804) (No. 8,670) (Fitzhugh, J.) ("In expounding statutes, the meaning of the legislature is to be ascertained, if possible, and the mischief defeated."); Burmus, 12 F. Cas. at 844 (Washington, Circuit Justice) ("To understand the provisio, it is always the safest way to discover the mischief or hardship to be removed ...."). 
transcend. In his opinion affirming the circuit court, Marshall found the statute itself grammatically ambiguous-an ambiguity easily removed once the practicalities of the situation were explored.449 Rather than reading an impossibility exception into the law, as Washington had done, Marshall reread the language of the statute to show that it did not really require such an impossibility. His opinion was a virtual merger of law and equity: The fair result provided the best way to make sense of the statutory scheme and its language. (As in the earlier cases, the opinion ignored statutory text that complicated the Chief Justice's story, in this case the 1803 statute that provided an equitable remedy within the executive department. ${ }^{450}$ ) This approach, too, had echoes among lower court judges. "No repugnancy or absurdity shall be presumed, especially in a statute, if the words will bear such a construction as to avoid it." 451

Whether Marshall was reading federal statutes narrowly or broadly, he was always alert to their broader legal context. Like the Jay and Ellsworth Courts, the Marshall Court construed statutes to be consistent with the Constitution (except in Marbury) and the law of nations (as in Seeman). For an aggressive example of the first point, Ex parte Bollman ruled that section 14 of the Judiciary Act authorized the Supreme Court to issue writs of habeas corpus cum causa. ${ }^{452}$ The government maintained that the first sentence of section 14, authorizing federal courts to issue writs of habeas corpus and other writs, was limited by its terms to cases where the writ was "necessary for the exercise of their respective jurisdictions." 453 Only the second sentence of section 14, limited to individual judges in their chambers, allowed habeas as an "inquiry into the cause of commitment," as Bollman was requesting. ${ }^{454}$ This was a good letter-ofthe-law plain meaning argument, yet not one the Court was prepared to accept.

449. See United States v. Willings \& Francis, 8 U.S. (4 Cranch) 48, 55-57 (1807).

450. Had Marshall bothered to answer this point, he could have dismissed the 1803 statute as, at best, a (subsequent) "legislative construction" carrying no great weight for judges seeking the true meaning of the 1797 law. Marshall, however, relied on a subsequent statute to inform his reading of various re-capture laws in Talbot v. Seeman, 5 U.S. (1 Cranch) 1, 34-35 (1801).

451. Hammond, 26 F. Cas. at 97.

452. 8 U.S. (4 Cranch) 75, 101 (1807). Justices Johnson (a friend of Jefferson) and Chase (a letter-of-the-law jurist) dissented from the Court's ruling. 1d. at 101-07. For an excellent historiographical treatment of Bollman, see Eric M. Freedman, Milestones in Habeas Corpus: Part I: Just Because John Marshall Said It, Doesn't Make It So: Ex parte Bollman and the Illusory Prohibition on the Federal Writ of Habeas Corpus for State Prisoners in the Judiciary Act of 1789, 51 Ala. L. Rev. 531, 558-74 (2000) (demonstrating that Marshall's bold holding, allowing the writ for men accused as conspirators in the Aaron Burr treason plot, was purchased at the expense of wrongheaded dicta taking a narrow view of the habeas power for state prisoners).

453. Bollman, 8 U.S. (4 Cranch) at 94.

454. $1 \mathrm{~d}$. 
Marshall suggested there was a grammatical objection to this argument but declined to rest the decision on linguistic niceties. ${ }^{455}$ Instead, "the sound construction which the court thinks it safer to adopt," was the one consistent with a central goal of the Constitution-to assure "that the privilege of the writ of habeas corpus should not be suspended, unless when, in cases of rebellion or invasion, the public safety might require it." 456 "Acting under the immediate influence of this injunction, they [Congress in 1789] must have felt, with peculiar force, the obligation of providing efficient means by which this great constitutional privilege should receive life and activity ..."457 Given the centrality of this writ to the liberty assured by the Constitution, as well as the common law, the Chief Justice reasoned that "congress could never intend to give a power of this kind to one of the judges of this court, which is refused to all of them when assembled. ... This is not consistent with the genius of our legislation, nor with the course of our judicial proceedings." 458 To reconcile the first and second sentences of the confusing statute, Marshall concluded that "the first sentence vests this power in all courts of the United States; but as those courts are not always in session, the second sentence vests it in every justice or judge of the United States."459 Marshall cemented his argument with precedent: the Court had already resolved the issue of its habeas jurisdiction by granting the writ in the 1795 case of United States v. Hamilton. ${ }^{460}$

Bollman was one of Marshall's boldest as well as least text-based decisions. Bollman was allegedly part of the Aaron Burr conspiracy to overthrow the Jefferson Administration. Granting the habeas petition over the dissent of Jefferson's first nominee to the Court, Justice Johnson, and then presiding over the trial that acquitted Burr himself of treason, ${ }^{461}$

455. Marshall noted the rule of the last antecedent: Because the limiting language of the first sentence followed "all other writs not specially provided for by statute," it only modified that item in the list, and not the habeas corpus item. Id. at 95. As the Chief Justice surely recognized, this was a weak argument, in part because a comma set off the qualifying phrase from the items in the list, see Lawrence M. Solan, The Language of Judges 29-38 (1993) (maintaining that last antecedent rule-weak to begin with-does not apply when the modifying phrase is set off from list by comma), and in part because the point of the first sentence seems to be the qualification, with no apparent reason for limiting it only to the third catch-all item in the list.

456. Bollman, 8 U.S. (4 Cranch) at 95 (quoting U.S. Const. art. 1, \$9).

457. Id.

458. 1d. at 96 .

459. 1d.

460. Id. at 100; see United States v. Hamilton, 3 U.S. (3 Dall.) 17 (1795). The Court in Hamilion, however, did not explicitly address the jurisdiction question, and so it is a particularly weak precedent in this regard. Justice Johnson's dissent in Bollman further argued that it was overtaken by Marbury, which had held that Congress could not add to the Court's jurisdiction except in appellate cases. Bollman, 8 U.S. (4 Cranch) at 104. Johnson viewed habeas as neither original nor appellate jurisdiction; Marshall characterized habeas as an exercise in appellate jurisdiction. Id. at 100-01, 104-05.

461. See United States v. Burr, 25 F. Cas. 55, 159-61 (C.C.D. Va. 1807) (No. 14,693), where Marshall delivered a series of opinions and jury charges that narrowly construed the 
Marshall embroiled the Court in fresh controversy at the end of the period under examination, even as he reaffirmed the Court's steadfastness as guarantor of the rule of law. Marshall's solicitude for the rights of the accused was in striking contrast to previous Justices' eager participation in prosecutions for participation in the Western Insurgency of 1794 and violations of the Seditious Libel Act of 1798. It was also under his leadership that the Court ruled that it would not recognize common law crimes, ${ }^{462}$ that ambiguities in penal statutes should be construed against the government, ${ }^{463}$ and that forfeiture statutes should be narrowly construed. ${ }^{464}$

Just as Marshall fit statutes into the larger fabric of constitutional and common law, so he also fit them into the fabric of international law. Seeman was his first exercise in this kind of construction, but the most celebrated was Murray $v$. Schooner Charming Betsy. ${ }^{465}$ The issue was whether the Non-Intercourse Act of $1800^{466}$ had been violated when an American vessel, which had been sold to a Danish burgher, was seized on its way to Guadaloupe, a possession of France, the object of the act's nonintercourse. The law's words did not cover this situation, ${ }^{467}$ but Marshall declined to decide the case on the bare words. Instead, he started with various interpretive presumptions, chiefly, that "an act of Congress ought never to be construed to violate the law of nations if any other possible construction remains, and consequently can never be construed to violate neutral rights, or to affect neutral commerce, further than is warranted by the law of nations as understood in this country." 468

law of treason by reference to English law, norms of justice, and constitutional principles. Interestingly, Marshall retreated from some broad dicta in Bollman. See id. at 161. After Marshall's ameliorative charge, the jury acquitted Burr of treason. See id. at 180-81.

462. Compare United States v. McGill, 26 F. Cas. 1088, 1090 (C.C.D. Pa. 1806) (No. 15,676) (Peters \& Washington, JJ.) (refusing to create common law crime), with United States v. Lindsay, 26 F. Cas. 971, 971 (C.C.D.C. 1805) (No. 15,602) (recognizing common law crime for selling liquor to disorderly [black] people). Marshall's opinion in United States v. Hudson \& Goodwin, 11 U.S. (7 Cranch.) 21 (1812), ruled that federal courts could not recognize common law crimes.

463. See United States v. Wiltberger, 18 U.S. (5 Wheat.) 35, 48 (1820); United States v. Sheldon, 15 U.S. (2 Wheat.) 57, 58 (1817).

464. See Schooner Paulina's Cargo v. United States, 11 U.S. (7 Cranch) 34, 40-43 (1812) (narrowing two separate forfeiture laws adopted to enforce national embargo, lest such statutes be applied to normal coasting and other trade not falling within statutory mischiefs).

465. 6 U.S. (2 Cranch) 64 (1804).

466. Act of Feb. 27, 1800, 2 Stat. 7.

467. Section 1 of the Act only applied to persons resident in or citizens of the United States, which the Danish burgher was not, or to American citizens seeking to evade the law by sale to a foreigner (a mens rea for which there was no evidence in this case). $\$ 1,2$ Stat. at $7-8$.

468. Charming Betsy, 6 U.S. (2 Cranch) at 118. Also, Marshall stressed that disruption of the "profitable business" whereby American shipbuilders would sell vessels to neutrals "Congress cannot be intended to have prohibited, unless that intent be manifested by express words or a very plain and necessary implication." Id. 
Even without such presumption, there was little doubt the act did not apply. ${ }^{469}$

By 1807 , the Supreme Court had not only weathered the Republican assault on its independence, but had laid the foundations for its central role in American public discourse. Greatly strengthened by the addition of Joseph Story as Associate Justice in 1811, the Court flowered in the next quarter century. During that time, the Marshall Court deployed Fisher's implied-powers idea to assert ever-broader authority for the federal government and an expansive spirit-based method for construing the Constitution, ${ }^{470}$ aggressively construed federal jurisdictional rules and applied Marbury-like judicial review to state statutes, ${ }^{471}$ established a substantive rule of lenity for construing federal criminal statutes, ${ }^{472}$ and vigorously and often innovatively implemented the statutory schemes developed by the political branches. ${ }^{473}$ In both statutory and constitutional cases, Marshall's method was a discreet synthesis of law and equity, construing "the literal meaning of the words" with a view to "the general objects to be accomplished by [them]," as well as fundamental and abiding legal principles. ${ }^{474}$

\section{Provisional Conclusions About Early Federal Statutory Decisions}

Professor John Yoo, a leading commentator on early American statutory practice, has argued that before 1801 "[c]onfusion reigned due to the Court's failure to adopt any consistent procedure or rationale" for reconciling the competing law and equity traditions. "Under Marshall, the Court resolved the tension between equity and judicial discretion in an innovative way. The Court made the intent of the legislature, as ex-

469. For a more elegant application of international law to a more difficult problem, see Marshall's opinion in Blane v. Drummond, 3 F. Cas. 681, 682-85 (C.C.D. Va. 1803) (No. 1,531) (concluding that assignees of bankrupt person in England cannot sue debtor in Virginia in their own name).

470. See McCulloch v. Maryland, 17 U.S. (4 Wheat.) 316, 420-21 (1819).

471. See Cohens v. Virginia, 19 U.S. (6 Wheat.) 264; 413-23 (1821); Martin v. Hunter's Lessee, 14 U.S. (1 Wheat) 304; 336-50 (1816). For an excellent analysis of the Court's jursidictional cases, see White, Marshall Court, supra note 407, at 485-594.

472. See United States v. Wiltberger, 18 U.S. (5 Wheat.) 76, 92 (1820); United States v. Sheldon, 15 U.S. (2 Wheat.) 119, 121 (1817). But compare United States v. Palmer, 16 U.S. (3 Wheat.) 610,627-32 (1818) (declining to apply the rule of lenity when application is supported by clear words and purpose of statute), with id. at 635-36 (Johnson, J., dissenting) (arguing that statutory words support defendants and, even if ambiguous, should be construed their way).

473. See Osborn v. Bank of the United States, 22 U.S. (9 Wheat.) 738, 817-18 (1824) (employing broad construction of Bank Act, assuring federal jurisdiction in all cases involving the Bank of the United States); McCulloch v. Maryland, 17 U.S. (4 Wheat.) 159, 213 (1819) (holding Bank of the United States immune from state taxation).

474. The quotes are from Brown v. Maryland, 25 U.S. (12 Wheat.) 266, 277 (1827), a constitutional case, and the idea is derived from White, Marshall Court, supra note 407, at 8. Note also the echo of Marshall's argument in Bracken, see supra notes 136-139 and accompanying text. 
pressed in the text, the controlling factor in construing the laws." 475 Manning follows this line. ${ }^{476} \mathrm{I}$ do not.

There was neither unusual "confusion" among federal judges in the 1790 s, nor a sea change after 1801. Instead, there is substantial continuity of judicial practice between 1783 and 1807. State judges of the 1780 s and 1790s, and federal judges in the Jay, Ellsworth, and early Marshall Courts followed roughly the same kind of methodology in statutory cases:

- The words of the statute were critically important and were read to be coherent with ordinary usage, the remainder of the statute and other relevant laws, constitutional principles, the spirit of the statute and the intent of the legislature, the common law, the law of nations, and various canons of statutory construction such as those collected in Bacon's Abridgment;

The letter of the law either gave way to, or was understood in light of, the "fundamental law," including not just state and federal constitutions, but also what judges variously termed the general law, the common law, and the law of nations; and

- The ordinary usage of words was usually the surest guide to statutory meaning, but sometimes the (imputed) legislative intent required narrowing or extending the ordinary meaning of the letter of the law to include omitted cases or to exclude unreasonable applications, lest a literal application of the statute undermine the spirit of the law, impede its ability to regulate the mischiefs identified by the legislature, or create unreasonable consequences the legislature should not be assumed to have wanted.

- Neither state nor federal judges in this period held themselves out as officials authorized to impose their "will" onto statutes or to engage in "legislative" activities, nor did judges present themselves as having "discretion" to depart from statutory language they did not like as a policy matter. Throughout, judges presented themselves as Blackstonian discoverers of the law. In statutory cases, logos was the object of inquiry, but discovery of the words' meaning entailed a process whereby the great judges-McKean, Duane, Wilson, Iredell, Ellsworth, Marshall (all of whom were important in the campaign for ratification of the Constitution) - understood the words through a process by which the entire legal landscape came into play. That the interpretation was external to the judge did not entail that it was bound by the text or the actual expectations of the legislature.

475. John Choon Yoo, Note, Marshall's Plan: The Early Supreme Court and Statutory Interpretation, 101 Yale L.J. 1607, 1615 (1992) (citation omitted) [hereinafter Yoo, Note].

476. See Manning, Equity of the Statute, supra note 8, at 86-88 (describing preMarshall Court statutory jurisprudence as "inconclusive"); id. at 89-102 (arguing that a "more definite" approach, following the legislature's intent as evidenced in its words, came to fruition under Marshall's tenure). 
Moreover, the evidence and the historiography do not support Manning and Yoo's presentation of the Marshall Court as an early prototype of the new textualism. To the extent that these authors portray Marshall as a judge who focused on the words of the statute and read them in light of the canons of statutory construction and various public law norms, they are simply presenting an extraordinary practitioner of the methodology deployed by earlier federal and state judges. To the extent that these authors portray Marshall as inaugurating the faithful agent theory in statutory cases and deploying that theory to insist upon judges' following the plain meaning of statutes, notwithstanding inequitable results, they have read their own views back into the earlier figure and have overlooked what Marshall actually said and did in the cases. Marshall did more with words than any other American judge, before or since. Often, he brilliantly analyzed and followed the literal import of the words (Fisher); only occasionally did he disregard them (Marbury). Most of the time, he smoothed over statutory edges that other sources of law considered rough. So the country's greatest Chief Justice ignored inconvenient clauses or strong-armed words when their literal application would unfairly restrict avenues for redress of important grievances (Bollman), unwittingly violate maritime practice and the law of nations (Seeman), unsettle measures taken to deal with foreign crises (Schooner Peggy), arbitrarily deprive a defendant of his liberty (the rule of lenity cases) or his property (Willing), and so forth. ${ }^{477}$

That I have documented a lot more continuity than these earlier authors found, and questioned their bootless allegation of "confusion" in the 1790 s, does not mean there was no change. Although federal judges' methodology in the 1790s and 1800 s was much like that of the state cases from the 1780s and 1790s, federal judges did emphasize the common law less and constitutional values more than the earlier state judges had. They also crafted their opinions with fewer references to equity and more

477. Realizing that there is suspicion afoot that Marshall actually "bent the text of the law," Manning responds-not by defending any of his decisions along textualist lines-but by confession and avoidance. According to Manning, Marshall's desire to justify his decisions by reference to the faithful agent theory and his insistence that text-bending requires "some exceptional justification" rescue the Chief Justice as an early hero of textualism. Manning, Equity of the Statute, supra note 8, at 99-100. Can that be squared with his opinions in Seeman, Schooner Peggy, Bollman, Marbury, the various Indian law cases (see Frickey, supra note 415), McCulloch, Osbom, and so forth? The short answer is "no." Marshall conceded that he was departing from the letter of the law in all those cases, except Marbury, where the departure was both most profound and most strategically motivated. To say that Marshall is an avatar of the faithful agent theory requires a lot more support than Manning is able to muster. Marshall's whole philosophy was that judges are agents of "We the People" and the law in all its forms. Not only was Marshall a devotee of Blackstone (anathema to the new textualists), but also of Lord Mansfield (the Antichrist!). Marshall considered Mansfield "one of the greatest Judges who ever sat on any bench," because he had "done more than any other to remove those technical impediments which grew out of a different state of society, \& too long continued to obstruct the course of substantial justice." Hobson, supra note 407, at 37 (quoting Marshall). 
references to logos. The Marshall Court made this shift dramatically apparent, because Marshall could go on for page after page analyzing statutory language and structure. This gift for extended (often gassy and obfuscating) textual analysis served the Court well. Marshall's many enemies (Jefferson and his allies) (pre)tended to be literalists in matters of interpretation. By exhaustive textual analysis and results tailored to the interests of his enemies, Marshall left them without any clear hook for complaint. For this reason, and surely others as well, early federal practice suggests a surprising twist on the ratification debates. Judges were just as theoretically attentive to the admonitions of Brutus (representing the losers) as to those of Publius (the winners). As Marshall put it in Fisher, the federal judiciary presented itself as applying statutes as they were written in the ordinary cases, and bending statutes only when necessary to conform to the larger fabric of the law-the "fundamental law"in the great cases. ${ }^{478}$ Beneath the rhetoric, however, federal judges during the Marshall Court were constructing statutes not so differently than state judges did in the $1780 \mathrm{~s}$.

Even within the framework of overall continuity, the Marshall Court was brilliantly innovative. For one thing, it spoke with virtually a single voice, rather than with the multiple voices reflected in the seriatim opinions of the Jay and Ellsworth Courts. ${ }^{479}$ There was just as much intellectual diversity on the Marshall Court as on the earlier Courts. For example, Justice Chase remained a literalist, Justice Washington favored equitable interpretations, and Justice Johnson was a states-oriented pragmatist. Unlike the earlier Courts, opinions for the Marshall Court usually spoke for all the Justices, and spoke more consistently from case to case. The dominant voice was the Chief Justice's, and it advances our understanding of statutory interpretation: Marshall's approach was emphatically textual and thickly contextual, simultaneously. The focus was on statutory words and structure, but the words were read in light of common law and other context to reflect principles.

Marshall was also either innovative or just plain brilliant in his strategic formalism. Formalism was a strategic move that prior Courts had appreciated, for that methodology presented the judiciary as the branch of government essential to a nonpartisan, objective, predictable rule of law in America-even when, especially when, the Court was exercising its greatest power, judicial review. ${ }^{480}$ Marshall's formalism was strategic in a politically more sophisticated way as well. He knew when to back away

478. See supra notes $434-441$ and accompanying text.

479. After 1801, the Justices largely ceased issuing seriatim opinions, as the Jay and Ellsworth Courts had done. Although Justices Washington and Johnson, in particular, sometimes disagreed with Chief Justice Marshall in statutory cases, the latter almost always wrote for the Court, and usually with no dissent. See White, Marshall Court, supra note 407 , at 349 .

480. The prevailing argument for judicial review was rooted in the rule of law: if two sources of law (a statute and the Constitution) direct a court to two different rules, the court must choose the superior source, namely the Constitution. See Marbury v. Madison, 
from strict formalist methods, but without renouncing formalism as a method. Unlike the majority in Chisholm, he knew when a stringent formalism would get his Court into trouble; like the majority in Ware, he also knew how a formalist presentation could strengthen a functionalist result. Thus, in Marshall's hands, inconvenient textual arguments would sometimes be ignored (Marbury), texts not completely clear would sometimes be presented as clear (Schooner Peggy and Fisher), incoherent texts would be straightened out (Bollman), and reasonably clear texts would sometimes be subjected to contextual analysis anyway (Charming Betsy) -all because the author had a larger agenda that could be advanced through these moves. In Marshall's case, that larger agenda was not just the personal one attributed to him, namely, embarrassing the Jefferson Administration, which he did cordially despise. Rather, the agenda was apparently a more principled one: situating the judiciary above politics and as the guarantor of a reasonably neutral rule of law, integrating statutes into fundamental law, and asserting a broad national power checked by constitutional limits. ${ }^{481}$ Consistent with the Hamiltonian vision for the judiciary, Marshall was also deploying formalism to position his Court as a body, outside of politics because it was professional and technocratic, that provided bedrock protections for Americans' everyday liberties and for a rough continuity of their fundamental rights and obligations. ${ }^{482}$

1 also view Marshall as the epitome of a method I call pragmatic textualism: The statutory text is the starting point and is thoroughly analyzed, as only lawyers can do, but must be read in light of legal and sometimes political context. An exemplar of this approach is Bollman. ${ }^{483}$ Conceding its ambiguities, Marshall started with-and constantly returned tothe text of the statute. Most of the opinion, however, was a deeper exploration of the legal terrain within which the provision must be situated: the constitutional assurance of habeas as a protection for individual liberty and Congress's general purpose to deliver on that assurance. Marshall sealed his case with the invocation of precedent: Whatever one's opinion of the ability of the Court to intervene in Bollman's highly controversial case, an American judge must follow the statutory interpreta-

5 U.S. (1 Cranch) 137, 177 (1803); The Federalist No. 78, at 466-68 (Alexander Hamilton) (Clinton Rossiter ed., 1961).

481. The observations in text are related to historian Sylvia Snowiss's argument that Marshall was a key figure in the legalization of fundamental law, whereby the vague English concept, bruited about by the likes of Coke and Mansfield, came to be concretized in a written Constitution that judges like Marshall were able to dissect using the traditional tools of the statutory technician. See Snowiss, supra note 236, at 64-65; see also Hobson, supra note 407, at 199 .

482. The point in text is inspired by Gordon Wood's argument that early federal judges, starting with those of the Jay Court and strongly continuing with the Marshall Court, were seeking to re-present themselves as legal professionals whose legitimacy was bolstered by their ability to knit together diverse pieces of law into a coherent whole. See Wood, Origins, supra note 75 , at 803-07.

483. Ex parte Bollman, 8 U.S. (4 Cranch) 75 (1807). 
tions laid down by prior Courts, and the Ellsworth Court's decision in Hamilton bound Marshall's Court to consider the writ. ${ }^{484}$

\section{The Relevance of the Founding History to Statutory INTERPRETATION TODAY?}

Like Manning and earlier authors, I consider the history of statutory interpretation theory and practice by the founding as well as subsequent generations intrinsically interesting but also potentially illuminating about current debates in statutory interpretation. 485 To begin with, American legal practice and early constitutional deliberations pose a genuine dilemma for the new textualists today. Textualists in statutory interpretation such as Scalia and Manning are originalists in constitutional construction-but the original expectations of the Framers were decidedly not any kind of strict textualism. If anything, the Framers practiced and preached a highly contextual approach which was open to revising, ameliorating, and bending statutory words in light of reason and fundamental law, including the law of nations. Their sophisticated, cosmopolitan approach to statutes is much more like that of Justice Stevens and my own theory than like that of Justice Scalia and Manning's theory. Read in light of the extensive historiography and original sources examined in this Article, the new textualists' statutory revisionism creates a crisis of sorts for constitutional originalists like Justice Scalia. Should they soften their claims about statutory interpretation? Surely so. Should they also re-present their statutory theories as more deeply contextual? You bet. Manning's article is the first big step in this direction, so good for him!

More illuminating are the lessons of my exegesis for the relationship among text, context, and the situated interpreter. The deepest intellectual error of textualist theory, as elaborated today, is its assertion that determination of textual plain meaning is segregable from normative context. John Marshall cannot be the hero of such a theory, as Professors Yoo and Manning make him. Marshall was a brilliant analyst, but the benefit of historical distance allows us to see that he ruled statutory texts, not vice-versa. A starkly textualist theory, especially at the Supreme Court level, is simply an impossible dream, and no Justice who has ever served could credibly carry it out for long. But Marshall's practice remains fabulously impressive, for he demonstrates how multifaceted analysis of

484. Id. at 100. In dissent, Justice Johnson argued that Hamilton had been abrogated by Marbury, which had ruled that Congress could not vest the Supreme Court with any further original jurisdiction cases than were listed in Article IlI, Section 2. 1d. at 104 (Johnson, J., dissenting). The Chief Justice responded with the claim that habeas petitions filed with the Court (without going through lower federal courts) are in the nature of appellate rather than original cases. ld. at 100-01 (Marshall, C.J.). This distinction has endured. E.g., Felker v. Turpin, 518 U.S. 651, 667 n.1 (1996) (Souter, J., concurring) (invoking distinction).

485. See Flaherty, History Lite, supra note 13, at 550-51 (citing reasons why history of framing period ought to be of interest to nonoriginalists). 
statutory texts can interweave with the broader legal landscape and public norms. That the judge is creative in the great cases does not mean that she or he is lawless. One way that creativity and law-faithfulness interact is through the canons of statutory construction. From Bacon and Blackstone to Yoo and Manning, the canons have been presented as constraints on judicial discretion-and judges from Marshall to Scalia have deployed the canons in creative, law-bending ways. From a new textualist perspective the malleability and evolution of the canons ought to be alarming. I am not as alarmed as they should be, so long as the evolution of the canons is open and public-regarding-a condition that the Marshall Court met better than subsequent Courts have.

\section{A. Original Intent about the Judicial Power in Statutory Interpretation? The Three Faces of Textualism}

For those who believe that the Constitution's authoritative power is based, at least in part, on its process of popular ratification, any consensus as to statutory practice among ratifiers provides some guidance for statutory interpreters today. Some of today's most ardent statutory textualists are constitutional originalists of this stripe; Justices Scalia and Thomas, Judge Easterbrook, and Professors Manning and Yoo come to mind.486 Scalia's book and several opinions on statutory interpretation defend a strict textualism by reference to the Constitution's separation of powers as well as the bicameralism and presentment requirements for legislation. ${ }^{487}$ As I have earlier demonstrated, these constitutional precepts provide no analytical support for his brand of textualism. ${ }^{488}$ This Article adds an historical dimension to my critique. The framing and ratifying discussions of statutory interpretation never occurred in the context of bicameralism and presentment, and were connected with separation of powers in a very different way than Scalia envisions. ${ }^{489}$ Instead, exactly as

486. See Manning, Equity of the Statute, supra note 8 , at $26-27$. The thinkers noted in text tend to be critical of reliance on the deliberations at the Philadelphia Convention, so Part III of this Article is irrelevant to them.

487. See Scalia, supra note 2, at 9-13, 34-35; cf. United States v. Taylor, 487 U.S. 326, 345 (1988) (Scalia, J., concurring in part) ("[W] hat the Members of the House and the Senators thought they were voting for, and what the President thought he was approving when he signed the bill, was what the text plainly said.").

488. See Eskridge, Unknown Ideal, supra note 7, at 1526-30.

489. In a most useful communication to me about this Article, Professor Yoo opined that my disagreement with him and Professor Manning is a "level of generality" debate. He and Manning rely on the Constitution's general principle of separate powers to support textualist method, while I rely on the more specific practices of the framing period. I respectfully disagree with this thoughtful defense, in part because I do not see how the Constitution established such a strict separation of powers that the neo-formalists support, see supra note 84 and accompanying text, and in part because the state and federal judges of the 1790 s were thinking about statutory interpretation in light of judicial independence and separation of powers as a protection of liberty-which suggested to men as diversely brilliant as Hamilton, Madison, McKean, Duane, Wilson, Iredell, and Ellsworth that what we would call "plain meaning" of statutory text was only part of the interpretive enterprise 
one would expect, the discussions occurred in the context of Article 111 and the "judicial Power" it conveyed on the Supreme Court and whatever inferior courts Congress would establish.

Serious originalist inquiry should therefore focus on Article III and any meaning the "judicial Power" would have had to the ratifiers or (possibly) to the ratifying generation. Thus, Manning's article is on the right track and, as a bonus, displays a healthy skepticism about what conclusions can be drawn from the disorderly materials of the founding period (1787-91). 1 join his skepticism. Originalism as a constitutional methodology is problematic for several reasons: The issues that engage us today, such as the admissibility of legislative history and the legitimacy of dynamic statutory interpretations, especially by agencies, were not ones our forebears attended to, and their discussions assumed a world vastly different from our own. ${ }^{490}$ Even when currently relevant issues, like the importance of statutory language and fair applications, were ones the Framers and ratifiers discussed, there are problems of generalizing the statements of some to the beliefs of all or even most of their contemporaries. ${ }^{491}$ It is far from clear that the Framers and ratifiers believed-or that we should believe-that their understandings should be binding on future generations. ${ }^{492}$ Ironically, most of these criticisms of originalism in constitutional interpretation were first made by John Marshall's Supreme Court

and that principles, public norms, and legislative policies were another important component.

490. This is the problem of anachronism or cbanged circumstances. See generally Paul Brest, The Misconceived Quest for the Original Understanding, 60 B.U. L. Rev. 204, 229-31 (1980) (critiquing strict originalism as ignoring the shifting of consensus over time); Martin S. Flaherty, The Practice of Faith, 65 Fordham L. Rev. 1565, 1565-80 (1997) (posing a further problem of shifting bistorical paradigms); Mark V. Tushnet, Following the Rules Laid Down: A Critique of Interpretivism and Neutral Principles, 96 Harv. L. Rev. 781, 786-804 (1983) (discussing the external and internal critiques of originalism, noting the limited vision of the Founders and the ambiguity of transposing former world views to modern society).

491. This is the aggregation problem. See generally Albert Furtwangler, The Authority of Publius: A Reading of the Federalist Papers 80-97 (1984) (making devastating critique of view that the Federalist Papers are authoritative evidence of ratifiers' intent); Rakove, Original Meanings, supra note 14, at 17-19 (explaining that the principle of popular sovereignty vests ratifying debates with special legitimacy, but that generalizing from thirteen different debates is speculative); Larry D. Kramer, Madison's Audience, 112 Harv. L. Rev. 611, 611 (1999) (arguing that The Federalist No. 10, emphasized by modern originalists, was marginal to the actual ratification debates).

492. This is the problem of intent about intent. See generally Rakove, Original Meanings, supra note 14, at 366-68 (showing that Madison thought it indefensible that his and other ratifiers' views should be binding on subsequent generations). Even if the ratifiers intended that we be bound by their intent, that does not answer the further question "what level of intent"-specific answers the Framers would have given, or merely the purpose of the Constitution or its provisions. Cf. Laurence H. Tribe \& Michael C. Dorf, Levels of Generality in the Definition of Rights, 57 U. Chi. L. Rev. 1057, 1086-1108 (1990) (arguing that "judges possess the requisite tools to make principled distinctions in the selection of a level of generality in defining fundamental rights"). 
partner and friend, Joseph Story. ${ }^{493}$ By the way, if one adheres to the kind of skeptical originalism that Manning and 1 both endorse, it would be very hard to justify the originalist activism the Supreme Court has shown in recent Tenth and Eleventh Amendment cases. ${ }^{494}$

But thoroughgoing originalists, like Justices Scalia and Thomas, must surmount these analytical hurdles or concede that their strict textualist approach to statutory interpretation has no connection to Article 111 and the original expectations of the ratifiers. This is troublesome for them, not only because they are constitutional originalists, but also because adoption of their approach would represent a major departure for the Court and therefore requires a particularly strong justification. ${ }^{495}$ My account provides originalist support for the proposition that statutory text (including the whole statute and related provisions) ought to be the primary source of statutory meaning. This was the English practice in the eighteenth century, the early state practice, the assumption of the Framers as well as both the defenders and opponents of the Constitution during ratification, and was the accepted view of federal judges implementing the constitutional design. But this proposition needs little defense today. We are all textualists.

But what kind of textualists? One conclusion I have drawn from engaging in debates with modern textualists and, now, in considering those debates from an originalist perspective, is that there are many ways you can be a textualist. The background and history of Article IIl help us evaluate the different kinds of textualism.

1. Strict (New) Textualism. - The new textualism of the sort defended and practiced by Justice Scalia has the following traits: (a) the statutory text, including the whole statute and related code provisions, is the focus of statutory interpretation, and statutory language needs to be understood in light of ordinary usage, established canons of construction, and precedent; (b) once the judge discerns a statutory plain meaning from the foregoing sources, there is no justification for further inquiry into (i) statutory purpose, (ii) administrative construction, or (iii) other

493. See 1 Joseph Story, Commentaries on the Constitution of the United States 391 (1833) (rejecting Jefferson's "spirit-of-the-original-debates" rule for construing the Constitution as "loose and incoheren $[\mathrm{t}]$ ").

494. See Seminole Tribe of Fla. v. Florida, 517 U.S. 44, 100 (1996) (Souter, J., dissenting) (showing the Court's Eleventh Amendment jurisprudence to be inconsistent with both constitutional text and original assumptions); Vicki C. Jackson, Federalism and the Uses and Limits of the Law: Printz and Principle?, 111 Harv. L. Rev. 2180, 2180 (1998) (criticizing the Court's Tenth Amendment jurisprudence along similar lines); Vicki C. Jackson, The Supreme Court, the Eleventh Amendment, and State Sovereign Immunity, 98 Yale L.J. 1, 1 (1988) (same).

495. See the sources in supra note 5 for the Court's traditional approach. This is why Scalia feels the need to make constitutional arguments for his position. So far those arguments have been unsuccessful, but I find greater cogency in the more moderate textualism constitutionally defended in John Manning, Textualism as a Nondelegation Doctrine, 97 Colum. L. Rev. 673, 731-39 (1997) [hereinafter Manning, Nondelegation]. 
legal context, such as substantive or constitutional canons-unless the plain meaning generates an "absurd result"; (c) legislative history as a general matter should be ignored, even when the statute has no plain meaning. ${ }^{496}$

Point (a) reflects the Supreme Court's longstanding practice and earns added normative support from my account of the historical context for the federal "judicial Power." A focus on the words of the whole statute was the primary rule suggested by Blackstone, characterizes the state court practice of the $1780 \mathrm{~s}$, is consistent with the discussions about the judicial power at Philadelphia and during the ratification campaign, is strongly supported by the principles underlying separation of powers and bicameralism/presentment in the Constitution, and is strongly supported by federal practice in the early years of the republic. The legisprudence of John Marshall is icing on the cake in support of this idea.

As to point (c), the original materials have little to say, as legislative history was not discussed one way or the other. The reasons for originalist silence are various. For the most part, legislative materials were not published and even if published were not widely available. The statutes construed in the first few decades of the new republic were ones whose legislative background was known to the early judges, without need for specific reference. Finally, eighteenth century lawyers did not understand legislatures as having "intents" in the subjective manner that some lawyers use the term today. ${ }^{497}$ One could argue from the originalist evidence that modern legislative history should be suspect, because its extensive use is an innovation in the way the Supreme Court interprets statutes or because it is in tension with the general principles of separation of powers and bicameralism/presentment. 1 consider the latter point dubious; the former (innovation) point is plausible, but I doubt it can carry the normative heft needed to oust more than one hundred years of federal court practice with legislative history. ${ }^{498}$

496. See generally Scalia, supra note 2, at 3-25, 29-37 (discussing textualism and criticizing the use of legislative history); Eskridge, New Textualism, supra note 4, at 650-66 (describing Scalia's brand of textualism); Manning, Equity of the Statute, supra note 8, at 105-25 (defending textualism and describing use of background principles when plain meaning leads to absurd results).

497. See Powell, supra note 42, at 897-98 n.60. Recall that eighteenth-century judges deployed the concept of intent as a way to impute objective or widely accepted purposes or concepts of reasonableness to legislatures. See id. at 894-96; supra note 96 and accompanying text.

498. See William N. Eskridge, Jr., Legislative History Values, 66 Chi.-Kent L. Rev. 365, 365-66 (1992). For the persistence of legislative history even today, see FDA v. Brown \& Williamson Tobacco Corp., 529 U.S. 120, 143-159, 181-192 (2000), where all nine Justices lavishly debated the nuances of legislative history. The Court's new textualists joined the majority opinion, which contains the most exhaustive deployment of legislative history 1 have ever seen in a Supreme Court opinion. This history was deployed in an effort to refute the dissenting Justices' view that the agency rule was well within the words used in the statute. 
Point (b) is another feature of the new textualism that represents a significant departure from the Court's practice in the twentieth century, and is least consistent with the original understandings of Article 1II. Scalia's strong version of the plain meaning rule was clearly not the English practice, even as articulated by the conservative Blackstone, nor was it the practice of the early state courts; it was not the position of any Framer or any supporter of the Constitution in the ratification debates; it was specifically rejected by leading ratifiers such as Hamilton and Duane (New York), Wilson and McKean (Pennsylvania), Ellsworth (Connecticut), Iredell (North Carolina), and Madison and Marshall (Virginia); and, finally, it was not the practice of the early federal judges-not even of John Marshall, who almost never halted his inquiry once he was persuaded there was a plain meaning, and who frequently adjusted statutory words. Where all of the evidence providing the historical context of Article III points in the same direction, even some nonoriginalists might take note. ${ }^{499}$

Point (b) becomes particularly problematic when strict textualists take a dogmatic view of a potentially ambiguous statute's plain meaning, either by refusing to recognize alternative usages or by strong-arming statutory language into an artificial clarity. Unfortunately, this has been the frequent practice of the Rehnquist Court generally and of its most textualist Justices specifically. For example, the Court in Chapman v. United States ruled that a statute requiring a minimum sentence of 20 years for distribution of one gram of a "mixture or substance" containing LSD included the full weight of blotter paper impregnated with the LSD. ${ }^{500}$ ln an opinion joined by Justice Scalia and affirming Judge Easterbrook, Chief Justice Rehnquist insisted on the law's plain meaning, notwithstanding the absurdity of applying the law in the context of the particular case, the lack of support for such a conclusion among linguists, ${ }^{501}$ and the tension such a harsh construction engendered with constitutional norms. ${ }^{502}$ Many of Justice Scalia's leading textualist opinions have similar problems. ${ }^{503}$

499. See Randy E. Barnett, An Originalism for Nonoriginalists, 45 Loy. L. Rev. 611 , 613-20 (1999).

500. 500 U.S. 453, 461-62 (1991), aff'g, United States v. Marshall, 908 F.2d 1312 (7th Cir. 1990) (en banc).

501. See Lawrence Solan, When Judges Use the Dictionary, 68 Am. Speech 50, 51-55 (1993).

502. See Marshall, 908 F.2d at 1332-34 (Posner, C.J., dissenting).

503. See, e.g., West Virginia Hosp. v. Casey, 499 U.S. 83, 100-02 (1991) (Scalia, J.) (holding that expert fees may not be shifted to losing party in civil rights case as reasonable "attorney's fees"), criticized in Lawrence M. Solan, Learning Our Limits: The Decline of Textualism in Statutory Cases, 1997 Wis. L. Rev. 235, 245-47, 258-60; Green v. Bock Laundry Mach. Co., 490 U.S. 504, 528-29 (1989) (Scalia, J., concurring in the judgment) (interpreting "defendant" as meaning "criminal defendant"), criticized in Eskridge, Dynamic Interpretation, supra note 2, at 42-47; Jett v. Dallas lndep. Sch. Dist., 491 U.S. 701, 738-39 (1989) (Scalia, J., concurring in the judgment) (arguing that section 1981 
Even more troubling has been textualists' tendency to narrow statutory language through the invocation of clear statement rules, including new ones or old ones toughened up for the occasion. ${ }^{504}$ For example, in EEOC v. Arabian American Oil Co., the Court refused to apply the broadly written text of Title VIl to asserted race discrimination by American companies against their American companies in foreign offices. ${ }^{505}$ Even though the statute was not only written broadly enough to include such claims, but contained provisions that assumed such claims, ${ }^{506}$ the Court announced a new rule whereby Congress could only assert extraterritorial jurisdiction if it did so clearly on the face of the statute. In my view, the Court in this case was acting neither as a faithful agent of Congress nor as a scrupulous reader of plain English-yet Justice Scalia went along with its result and reasoning. Some of his own opinions reflect a refusal to engage fully with statutory texts by opting for clear statement rules, which avoid analysis. ${ }^{507}$

2. A Kinder, Gentler Textualism. - Although Professor Manning repeatedly invokes Justice Scalia's opinions and has developed the Justice's constitutional arguments in a highly sophisticated way, he really has a different theory from that of his mentor. Thus, Manning is willing to examine contextual evidence, including legislative history, ${ }^{508}$ and analyzes statutory texts less dogmatically than Scalia does. ${ }^{509}$ To the extent that Manning offers a textualism tempered with reasonableness and equity, as he does in his article in this Review, ${ }^{510}$ it is more faithful to the original expectations of the Framers, defenders, and early implementers of Article 1II. To the extent that Manning's kinder, gentler textualism

cannot establish liability by a state actor that is excluded in the more closely related and specific section 1983), criticized in Eskridge, New Textualism, supra note 4, at 675-76.

504. For a critique of the Court's manipulation and creative use of clear statement rules, see William N. Eskridge, Jr. \& Philip P. Frickey, The Supreme Court, 1993 TermForeword: Law as Equilibrium, 108 Harv. L. Rev. 26, 81-87 (1994); see also William N. Eskridge, Jr. \& Philip P. Frickey, Quasi-Constitutional Law: Clear Statement Rules as Constitutional Lawmaking, 45 Vand. L. Rev. 593, 595-98 (1992) [hereinafter Eskridge \& Frickey, Clear Statement Rules] (criticizing clear statement rule).

505. 499 U.S. 244, 246-47 (1991).

506. See id. at 266-71 (Marshall, J., dissenting).

507. See, e.g., United States v. Nordic Village, Inc., 503 U.S. 30, 33-37 (1992) (Scalia, $\mathrm{J}$.) (holding that waiver of government's sovereign immunity in action seeking recovery in bankruptcy must be unequivocally expressed).

508. See Manning, Nondelegation, supra note 495, at 731-33 (arguing that legislative history such as committee reports cannot be considered authoritative but may be useful contextual evidence of textual meaning).

509. But there is much overlap between Manning's spin and Scalia's performance. For example, Scalia's dissenting opinion in Smith v. United States, 508 U.S. 223, 241-42 (1993) (Scalia, J., dissenting) (arguing that sentence enhancement for use of firearm during and in relation to a drug crime should not have applied because "use" of a firearm implied use as a weapon, not as an item for trade), is exemplary of a reasonable user textualism which is sensitive to context and even equity. Cf. Manning, Nondelegation, supra note 495 , at $702-05$ (discussing Scalia's statutory analysis in two separate cases).

510. See Manning, Equity of the Statute, supra note 8, at 105-26. 
insists that statutory plain meaning cannot yield to equitable or legislative purpose considerations that do not rise to the level of absurdity, it is inconsistent with these original materials. Like the plain meaning rule, the narrowness of the absurd result exception is an idea more characteristic of the twentieth century than the eighteenth.

The plain meaning rule, nascent in the founding period and fullblown in the late nineteenth and early twentieth centuries, should be gentle rather than rigid. Under the traditional plain meaning rule, once the interpreter believes he or she has discerned the plain meaning of the statute, contextual inquiry ceases. This rule is often applied abrasively, seemingly as a means of cutting off contextual inquiry, and with arbitrary results. One way the rule can be applied more gently is at the beginning: The statute must be plain to a reasonable reader, as Manning suggests. ${ }^{511}$ This was the approach Marshall followed in Willing. ${ }^{512}$ Linguist Lawrence Solan has made a most useful textualist suggestion: When Congress uses words, presume that the words are limited to their prototypical senses, unless the words are terms of art or unless the statutory purpose (often set forth on the face of the statute nowadays) requires a broader reading. ${ }^{513}$

Another way the rule can be opened up is at the end: Plain meaning is the presumptive right answer but does not terminate further contextual inquiry. This was the approach Marshall followed in Fisher, where his opinion was a thorough reflection on the consequences of the broad statutory exemption for bankruptcy policy and individual property and contract rights. ${ }^{514}$ An even gentler rule, which $\mathrm{I}$ think inspired Marshall's great opinions, is that words are vessels for principles, and the interpretive task is to apply the letter of the law to specific and often unforeseen factual circumstances in light of the whole legal landscape.

3. Pragmatic Textualism. - The founding and consolidating era materials provide some normative support for a pragmatic textualism in statutory interpretation, of the sort that Phil Frickey and I have defended theoretically515 and that Justices John Paul Stevens, Sandra Day O'Connor, David Souter, and Stephen Breyer have applied in Supreme Court cases. ${ }^{516}$ Thus, the English case law and treatises and the early state practice emphasized statutory text and usually applied what we would call plain meanings, but also gave judges leeway to soften texts

511. See Manning, Equity of the Statute, supra note 8, at 108-15.

512. United States v. Willings \& Francis, 8 U.S. (4 Cranch) 48, 55-59 (1807); see supra notes 449-451 and accompanying text.

513. See Solan, supra note 503, at 270-78 (using Bailey v. United States, 516 U.S. 137 (1995), to show how textualism can be reasonable and equitable but should not draw hard lines against considering legislative materials in exploring the words of the statute).

514. United States v. Fisher, 6 U.S. (2 Cranch) 358, 385-97 (1805); see supra notes 434-440 and accompanying text.

515. See Eskridge \& Frickey, Practical Reasoning, supra note 5, at 345-84.

516. See Charles Tiefer, The Reconceptualization of Legislative History in the Supreme Court, 2000 Wis. L. Rev. 205, 209-10, for an analysis of the approach taken by these Justices in recent cases, and their rejection of strict textualism. 
when fundamental rights were involved or to extend texts when needed to fulfill statutory purposes. That practice was the background for the framing discussions, which added the caveat that judges should not use this power to read their own policy views into statutes. The ratification debates accepted these premises and made clear that federal judges would have more authority to ameliorate statutes trenching on fundamental rights than to expand federal statutes. Chief Justice Marshall's opinions in Bollman and Seeman are classics of this genre. On the other hand, modestly expansive readings of statutory words can be appropriate when needed to carry out important statutory policies or achieve surpassing national goals. Marshall's opinions in Seeman, Schooner Peggy, and Fisher are classics of this genre.

Pragmatic interpretation considers statutory texts relevant and dispositive but insists that the proper reading of them depends on context. In addition to the facts of the case and fundamental law, pragmatic context also includes the particular history and norms characteristic of the field of law in which the statute is situated. In the founding and consolidating periods, the best contrast is between criminal statutes and laws regulating admiralty matters. Consistent with the rule of lenity and the liberty values at stake, judges generally stuck to the texts of the former and gave them narrow readings. Consistent with admiralty's equitable history, judges read the latter very broadly and sometimes quite creatively. Early judges also read procedure statutes pretty flexibly, usually with an eye on basic ideas of procedural fairness. Just as these early areas of American law called for different strategies of interpretation because of their own internal norms, so does statute law today. Whereas tax statutes probably should be applied in a manner consistent with their plain meanings and accompanying legislative history, administrative and procedure statutes should be construed more purposively and flexibly. ${ }^{517}$ Modern scholars of statutory interpretation need to be more attentive to the field-sensitive norms that undermine the global applicability of any foundational approach to statutory interpretation.

A further feature of pragmatic theories of interpretation is their attention to institutional and even political context. The Supreme Court, for example, has more leeway to bend a statute's plain meaning than a circuit court does, because the lower court is more likely to be reviewed and to be disciplined for risk-taking than is the highest court. When the political process is normatively invested in a particular statute, the Supreme Court itself is likely to be disciplined for an interpretation at odds with the prevailing political consensus. When the political process is suspicious of or hostile to the Court, dictionaries will not save its decisions. Yet, in a strategic context such as this, textualism is sometimes the best

517. See Jonathan R. Siegel, Textualism and Contextualism in Administrative Law, 78 B.U. L. Rev. 1023, 1033-41, 1055 (1998) (contrasting the contextualist approach that should be used in administrative law cases with a more rule-based approach in tax cases because "[ $t]$ here is no 'background' tax rate"). 
strategy. But a heavy-handed or dogmatic textualism is generally a bad strategy, as illustrated by the consolidating period. The biggest blunder of the period-Chisholm-involved a statute the majority Justices read too literally and may have erred in not narrowing, and the biggest triumphMarbury-involved a statute the Justices rewrote in order to make a broader strategic point. The Justice most like Scalia and Thomas methodologically-Chase-was the only Justice impeached in the history of the Court, while the Justice most like Stevens and O'Connor methodologically-Marshall-was the greatest in our history.

\section{B. The Relationship Between Text and Context}

My most subtle but also most fundamental disagreement with the textualisms of both Manning and Scalia is that I do not accept a premise of their textualism, namely, that discernment of plain meaning is independent of norms and other nontextual considerations such as precedent, legislative history and purpose, practice, and fairness. ${ }^{518} \mathrm{ln}$ most cases, the connection between fact and value is invisible. The fact of communicative utterance, as understood by the interpreter, fits snugly with what she thinks is reasonable under the circumstances. Sometimes fact will be softened by value. If I tell you, "Drop everything and come to me," you will not drop the vase you are carrying, yet without any consciousness that you are not following the strict meaning of my directive. Other times value will be informed by fact. If the state says you must wear seat belts, you may adjust your attitudes to believe that seat belts are good.

The connection between fact and value gets exposed in the great cases-the cases that raise tough normative issues for incompletely specified statutes. Because there is much reasonable play at both the descriptive (plain meaning) and normative levels, the great cases test both textualist and contextualist theories. Foundationalist theories of any kind (plain meaning, original intent, simple purpose) usually fail such tests. For me, a big reward of this Article's survey was discovering that the founding and consolidating periods generated great cases involving statutory interpretation-Bracken, Rutgers, and M'Claws at the state level, and Chisholm, Ware, Seeman, Schooner Peggy, Marbury, Fisher, and Bollman at the federal level. What makes these cases great is not just the important public law issues they presented, but also the dialectic between text and context they posed. The best legal minds of the era were involved in these cases: Hamilton, Marshall, Ellsworth, Jay, Wilson, Iredell (and Madison, as a defendant!). They all agreed that statutory text not only must be read in context, including relevant public norms and principles embodied in the common law, the law of nations, and the Constitution, but the interpreters (in my view) had some understanding of the modern concept that their interaction with authoritative texts was creating meaning

518. See William N. Eskridge, Jr., Gadamer/Statutory Interpretation, 90 Colum. L. Rev. 609, 610-12, 679-81 (1990). 
that was inchoate beforehand. This insight originates with Aristotle, whose approach was carried forward by Plowden and the English equitable construction cases. Our nation's founders understood this intuition at some level. This idea informs my reading of Hamilton's The Federalist 78, and Madison made this point explicitly in The Federalist 37: "All new laws, though penned with the greatest technical skill and passed on the fullest and most mature deliberation, are considered as more or less obscure and equivocal, until their meaning be liquidated and ascertained by a series of particular discussions and adjudications." 519

Many of the cases decided in the founding and consolidating periods could be cited as examples of the plain meaning rule, but the best reading of those cases suggests that textual plain meaning cannot be separated from statutory policy, fundamental principles, and other contextual considerations. For an early example, the federal prize court's 1782 decision in Miller v. The Ship Resolution (holding that neutral ships were not subject to statutory capture) both exemplifies and complexifies the notion of a plain meaning rule. ${ }^{520}$ The judges started with and focused on the statutory text, but to determine the meaning of the key term "prize" they looked to international law and practice and attributed that understanding to Congress. Plain meaning is unintelligible without thick legal context. The Miller opinion was openly contextualist, but the clinching context was a subsequently enacted ordinance. Legal context itself is formed by surrounding statutory texts. This is the point of the whole act rule.

Contrariwise, the Attorney General and some of the Justices were wrong in Chisholm to suggest that the Judiciary Act had a plain meaning simply because it gave federal jurisdiction for suits among states and citizens of other states, without distinguishing between cases where states were defendants and those where they were plaintiffs. There was a history against which the statute was written: the common law immunity of the states, charges and denials during the ratification debates that Article III would abolish that immunity, and various decisions made in the drafting of the Judiciary Act which suggested its sensitivity to claims of state autonomy.521 If I tell you, "Fetch me three pounds of soupmeat," that directive's plain meaning is dependent on its historical and normative background. If our practice has long been that soupmeat means a particular kind of beef, then the plain meaning presumptively reflects that. That there was no simple plain meaning does not mean that Chisholm was wrongly decided, necessarily. Justice Wilson's opinion supporting the majority's result read the Judiciary Act in light of the transformation wrought by the Constitution. Because the new founding rested upon a

519. The Federalist No. 37, at 229 (James Madison) (Clinton Rossiter ed., 1961).

520. 2 U.S. (2 Dall.) 1 (1781). See discussion at supra notes 97-101 and accompanying text.

521. For example, the Act provided no mechanism by which judgments against the states could be executed. 
new conception of sovereignty-"We the People," not "The States Assembled"-Wilson maintained that common law notions of state sovereign immunity were not appropriate in the national court system. ${ }^{522}$ Whether right or wrong, this was a sensible argument. It illustrates how plain meaning depends on normative assumptions as well as descriptive ones. ${ }^{523}$

Rutgers and Ware were both cases where patriot claimants could rely on the plain meaning of state laws giving them rights against loyalists and former enemies-yet these "plain meanings" could not be sustained in light of the Treaty of Paris ending the Revolution. Ware also presented a nice issue of the treaty's meaning. Although the Justices presented Ware as a plain meaning case, it was in my view a great deal more, for the holding was not required-and perhaps not supported-by Article IV's plain meaning. ${ }^{524}$ Yet, unlike their exercise in Chisholm, the Court decided this case correctly. The Justices were all cognizant that the purpose of Article IV was to nullify the nettlesome state laws, no matter how ingenious, that had been devised to deny British creditors payment of debts owed them by patriots, and the purpose of the Treaty of Paris was apparently to nullify any and all state laws impeding collection. If knowledge of the 1783 treaty were not enough, the Justices were surely also aware that Congress had debated this issue in 1794 (after the trial in Ware but before the Court's opinion) and had defeated bills to renounce pre-war debts. ${ }^{525}$ The Justices were aware that their former Chief Justice, John Jay, had in I 795 negotiated a new treaty in which the United States government itself had promised to pay debts that British creditors were not able to collect under the normal legal process. ${ }^{526}$ Moreover, the Justices probably knew that the government had committed the country to the controversial treaty; that opposing the treaty had cost John Rutledge Senate confirmation as Chief Justice; and that a firm resolution of the debt matter was necessary for any kind of normal relations with Great Britain, as well as, possibly, with other countries. ${ }^{527}$ The overall political and international context created the interpretive baseline in Ware just as much as the language of the 1783 treaty. That some of the Justices genuinely thought

522. Chisholm v. Georgia, 2 U.S. (2 Dall.) 419, 453-57 (1793) (Wilson, J.).

523. For a similar debate, in which the background assumption about popular-versusstate sovereignty critically affects how one reads the historical evidence, compare U.S. Term Limits, Inc. v. Thornton, 514 U.S. 779, 803 (1995) (starting with assumption that Framers rejected idea that nation was collection of states, and reading constitutional text and historical materials to deny states power to impose term limits on their national representatives), with id. at 846 (Thomas, J., dissenting) (starting with the assumption that the nation was a collection of states, and reading same materials to conclude that states could impose term limits on their national representatives).

524. See supra notes $362-370$ and accompanying text.

525. See IV Annals of Congress 535 \& 715-16 (May 25, 1794) (defeating motion to vote on House resolve); id. at 94 (May 6, 1794) (Senate defeating bill, with only the two Virginia senators in favor).

526. See Goebel, Antecedents, supra note 190, at 749 .

527. See id. at $748-49 \&$ n. 120 . 
that the treaty's words clearly covered the extinguished debts, when a modern observer would think there was considerable ambiguity, is testimony to the ability of thick context to bring closure to otherwise inchoate texts.

A lesson of Ware is that plain meaning can also depend on the legislative purpose that gave rise to the rule, the central point of Heydon's Case. This has bearing on the current debate about the use of legislative history. Justice Scalia's campaign to exclude it would deprive judges of frequently valuable background evidence about the linguistic as well as policy assumptions of the legislature-evidence that helps judges evaluate plain meaning arguments as well as intent and purpose ones. ${ }^{528}$ For example, the Court's willingness to narrow the statutory exemption in Priestman is plausible, but 1 would be much more comfortable with that inequitable result if 1 were more certain of the Court's assumptions about the statutory goal-a certainty that could best be acquired if there were committee reports explaining the statutory purposes and explaining how each section fit into the overall scheme. The same is true, for me, with Fisher.

Chief Judge Duane's opinion in Rutgers was important for its suggestion that the state law should be read in light of the Treaty of Paris and of the law of nations generally. Duane essentially rewrote state law to satisfy this norm, and in Charming Betsy Chief Justice Marshall announced the same norm as the premise for reading a federal law essentially the way it was written. In both cases, the jurists were making the point that textual meaning depends upon presumptions, and presumptions can be normatively inspired. We presume that the legislature does not adopt laws that traverse the rules of the Constitution (Chisholm), of treaty obligations (Ware), of international law (Charming Betsy), or even of the common law (M'Claws). 1t requires a clearer statement from the legislature before we shall believe its directives would derogate from these enduring sources of fundamental law. All the major judges of this period subscribed to this critical idea, the progeny of Bonham's Case.

\section{Insights About the Canons of Statutory Construction and Recent Decisions}

One thing that can be said with assurance is that judges and lawyers throughout the framing and consolidating periods understood the im-

528. See Eskridge, Unknown Ideal, supra note 7, at 1517-19, 1533-40 (showing that Scalia misanalyzes Church of the Holy Trinity v. United States, 143 U.S. 457 (1892), the only case example in A Matter of Interpretation, because he ignores the historical context of the statute, which we can learn about through study of legislative history). Compare Adrian Vermeule, Legislative History and the Limits of Judicial Competence: The Untold Story of Holy Trinity Church, 50 Stan. L. Rev. 1833, 1837 (1998) (arguing that the legislative history supports Scalia's conclusion), with Carol Chomsky, Unlocking The Mysteries of Holy Trinity: Spirit, Letter, and History in Statutory Interpretation, 100 Colum. L. Rev. 901, 907 (2000) (arguing that legislative materials and historical context support the Court's conclusion, not Scalia's). 
portance of the canons of statutory construction. ${ }^{529}$ Most were familiar with Bacon's list of dozens of canons in his Abridgment and with the shorter list in Blackstone's Commentaries. In my survey, I found no thinker questioning the canons as a methodology; contemporaries believed they brought greater order and predictability to the law. ${ }^{530}$ They were the lingua franca of statutory interpretation. No one appreciated the canons' ability to give a rule of law veneer to statutory cases more than John Marshall, but the Marshall Court was far from unique in presenting decisions as required by an orderly deployment of the canons, including textual canons, extrinsic source canons, and substantive canons. ${ }^{531}$

$1 \mathrm{t}$ is hard to grasp precisely what the consequences of this descriptive insight ought to be for modern practice. Influenced, or corrupted, by Karl Llewellyn's nasty list showing every canon to have a counter-canon negating it, ${ }^{532}$ we are more reluctant to believe that the canons "determine" (ex ante) rather than "justify" (ex post) judicial decisions in the hard cases. Perhaps the faith of the founders is better justified than Llewellyn's list would suggest. The canons may form an interpretive regime which at least puts the legislature and the citizenry on notice as to the rules of thumb judges will follow in applying statutes. ${ }^{533}$ In the same spirit, discourse about the canons helps us identify interpretive baselines that genuinely and perhaps deeply affect statutory applications.

In my view, debate and practice in the founding and consolidating periods do pose some normative canonical ideas. This concluding Section will present some hypotheses and suggest applications to two of the most controversial statutory decisions of the last generation: United Steelworkers $v$. Weber, ${ }^{534}$ where the Court interpreted Title VII's bar to job "discrimination" as not disallowing some voluntary affirmative action plans seeking to remedy underrepresentation of minorities, and BFP v. Resolution Trust Corp. ${ }^{535}$ where the Court construed the Bankruptcy Act's requirement that certain property transfers be in exchange for "a reasonably equivalent value" to be satisfied by any price fetched at a foreclosure

529. In addition to my survey in Parts II-V, supra, see also Molot, supra note 252, at 35-4I; Yoo, Note, supra note 475, at I609-I0, I6I8-29 (describing how Hamilton "saw the canons of construction as a source of law that could restrain Congress").

530. See Molot, supra note 252, at 35-36, 40-41 (discussing The Federalist No. 78). Please note, however, that some thinkers, including Brutus and Federal Farmer during the founding period and Justice Chase and Judge Peters during the consolidation period, objected to particular equity-based canons, which were found in Bacon and Blackstone. See supra notes $279-294,320,377-378$, and accompanying text.

531. See William N. Eskridge, Jr. \& Philip P. Frickey, The Supreme Court, 1993 Term-Foreword: Law as Equilibrium, I08 Harv. L. Rev. 26, 96-108 (1994) [hereinafter Eskeridge \& Frickey, Equilibrium] (including appendix that lists canons used by the Rehnquist Court, sorted in the manner described in the text).

532. Karl N. Llewellyn, Remarks on the Theory of Appellate Decision and the Rules or Canons about How Statutes Are to Be Construed, 3 Vand. L. Rev. 395, 401-06 (I950).

533. See Eskridge, Dynamic Interpretation, supra note 2, at 276.

534. 443 U.S. 193, 208 (1979).

535. 511 U.S. 531,545 (1994). 
sale. Both opinions have been assailed as violating statutory plain meanings and original legislative intent. ${ }^{536}$ The history of statutory interpretation in the founding and consolidating periods provides surprisingly supportive insights into these contentious cases.

Consider, for example, how a gentler plain meaning rule would work in these cases. Critics of Weber maintain that allowing race-based affirmative action is at best a benign form of discrimination-but therefore still "discrimination" in violation of the statute's clear command. ${ }^{537}$ In light of the foregoing discussion, one might wonder whether this is not too dogmatic a reading of the statutory term. "Discriminate" can certainly mean any differentiation, which would include benignly inspired affirmative action, but it can also mean disadvantaging someone else because of prejudice, which would not so readily embrace remedial action. ${ }^{538}$ Particularly in regard to such a contentious issue, it is injudicious to be so insistent that Title VIl has a plain meaning in the Weber case-especially when the Court was interpreting "discriminate" in its prototypical sense. Thus, both majority and dissenting Justices appropriately engaged in a thorough and illuminating discussion of the policy and deliberative context of the statutory language, as well as the subsequent history and interpretation of Title VII, to try to figure out which great antidiscrimination principle should have been read into the law for that case.

1. Contextual Application of Textualist Canons (Such as Inclusio Unius). - One lesson of my examination of the early cases is that application of the various textualist canons of statutory construction is anything but mechanical. For example, the history suggests caution in using the canon inclusio unius est exclusio alterius (the inclusion of one thing suggests the exclusion of all others). Inclusio unius cuts against the early federal judicial opinions in Darby $v$. The Brig Ersten and Seeman, yet those cases were in my view correctly decided. The reason has to do with normative baselines. In Seeman, for example, the baseline established by Congress was that American ships should be encouraged to re-capture vessels captured by enemy nations. Because there was no evident reason for the legislature to exclude situations where an enemy ship had captured a neutral vessel and turned it to their own uses-and indeed some evidence that

536. For the record, I am a defender of Weber, see Eskridge, Dynamic Interpretation, supra note 2, at 14-34, and a (most reluctant) critic of $B F P$, see Eskridge \& Frickey, Equilibrium, supra note 531, at 83-87.

537. E.g., Johnson v. Transp. Agency, 480 U.S. 616, 657-77 (1987) (Scalia, J., dissenting) (delivering a brilliant and outraged critique of Weber, and making one central textualist point, namely, that "discriminate" clearly includes affirmative action preferences).

538. Indeed, dictionaries of the 1960s, when Title VII was enacted, often gave the prejudice meaning as the first definition of discrimination-in contrast with today's dictionaries, which usually list the differentiation one first. See William N. Eskridge, Jr. et al., Legislation and Statutory Interpretation 225-26 n.25 (1999). For a host of other textual arguments relating to Weber, see Eskridge, Dynamic Interpretation, supra note 2, at 42-44. 
such situations were within the statutory scheme-inclusio unius was decidedly not appropriate. Instead, Seeman was an appropriate case for application of the equity of the statute to fill in a statutory gap, as the Court ruled.

Consider this thought experiment. Mother tells Sally, "You may not kick or pinch your sister Anne." Thinking inclusio unius, Sally hits her little sister. That is an abuse of both logic and the sister, for the normative baseline against which Mother was speaking was the principle, "do not harm sister." On the other hand, if Mother had told Sally, "You may have one scoop of ice cream and one cookie," inclusio unius properly suggests to Sally that she is not authorized to eat a candy bar. The baseline is, "only a few teeth-destroying non-nutritious snacks for children." This line of thinking supports the deployment of inclusio unius in Weber. Section $703(\mathrm{j})$ provided that Title VIl should not be applied to "require" employers to grant preferences based on race or sex. Justice Brennan's majority opinion reasoned from this prohibition that the statute could be applied to "permit" such preferences: Because Congress had only prohibited mandatory preferences, it had not prohibited voluntary ones. ${ }^{539}$ This is a correct use of the canon-but only if one assumes (as Brennan did) that the baseline norm of Title VI1 is to redress historic racial segregation in the workplace and exclusion of people of color from desirable jobs.

Other canons of construction must be understood the same way. For example, the canon noscitur a sociis (a thing is known by its associates) ought not be applied without consideration of statutory goals and purposes, as well as other legal values. Thus, the Court was right in Babbitt $v$. Sweet Home Chapter of Communities for a Great Oregon to read the statutory term "harm" in light of the strong purpose of the Endangered Species Act to protect endangered species against indirect as well as direct threats. ${ }^{540}$ Justice Scalia's effort, in dissent, to invoke noscitur a sociis was potentially persuasive, because "harm" was part of a list that included direct rather than indirect threats ("pursue," "shoot," "capture," etc.) ${ }^{541}$ but only if Congress had adopted the norm of state noninterference with private property use that did not directly threaten endangered species. Sweet Home illustrates my notion that norms will and must influence the reasonable person's understanding of texts. Nonetheless, that notion does not undermine the legitimacy of the Court's interpretation, because Justice Stevens's excellent opinion persuades me that he was internalizing the norms that Congress and administrative practice had set afoot. Creativity and normative influences are not the same as lawlessness. Because he was internalizing Congress's norms, and not his own, Justice Stevens's opinion exemplifies the rule of law in statutory interpretation.

539. Weber, 443 U.S. at 205-06.

540. 515 U.S. 687, 708 (1995).

541. Id. at 714-25 (Scalia, J., dissenting). 
2. Erring Amelioratively Is Better Than Erring Suppletively. - My historical excursus also lends startling support to Earl Maltz's neglected idea that statutory interpreters should be more willing to err by construing statutes too narrowly than too broadly. ${ }^{542}$ Starting with common law baselines, Maltz argues that a libertarian presumption ought to be generally relevant in statutory interpretation. Most of the state and early federal cases examined in this paper are consistent with Maltz's presumption, and it is further supported by the ratification debates. Recall that the Anti-Federalists were most afraid that federal judges would supplement national power through their constitutional and statutory interpretations as they endorsed narrowing interpretations, while the Federalists stressed the need for the latter while saying little or nothing in defense of the former.

Early federal practice lends mixed support to the hypothesis, however. Cases like Ware v. Hylton, Schooner Peggy, and Fisher are strongly statist, sacrificing private contracting rights to the public interest. Cases like Chisholm and Seeman are hard to characterize. The rule of lenity, which is highly libertarian, was unevenly deployed during the founding and consolidating periods. But decisions like Rutgers, M'Claws, Willing, and Bollman were highly libertarian. Although one may object to Maltz's hypothesis on the ground that the circumstances of the modern regulatory state require a rethinking of the Constitution's libertarian baselines, ${ }^{543}$ these early libertarian decisions (with the obvious exception of $M^{\prime}$ 'Claws) remain attractive today.

This kind of thesis lends support to the result as well as methodology in Weber, which was a libertarian interpretation of Title VIl. The common law rule was that employers could hire or promote whomever they wanted; Title VIl was a reversal of the common law rule. Weber limited the reach of that reversal, for it created a space where employers and unions could voluntarily rectify racial disparities in their workforces. ${ }^{544}$ It is ironic that Weber is the leading Supreme Court decision recently following Heydon's idea that statutes should be construed to fulfill the "spirit" of the statute, for the interpretation is ameliorative rather than suppletive. From the perspective of the founding and consolidating generations, the Burger Court's willingness to bend the statute in Weber was more defensi-

542. See Earl M. Maltz, Rhetoric and Reality in the Theory of Statutory Interpretation: Underenforcement, Overenforcement, and the Problem of Legislative Supremacy, 71 B.U. L. Rev. 767, 791-92 (1991).

543. See, e.g., 1 Bruce Ackerman, We the People: Foundations 6-10 (1991); 2 Bruce Ackerman, We the People: Transformations 72-80 (1998).

544. Note, however, that the state created strong incentives for employers and unions to engage in private remediation. The Johnson and Nixon Administrations required federal contractors to achieve racial balance, see United Steelworkers v. Weber, 443 U.S. 193, 223 n.2 (1979) (Rehnquist, J., dissenting), and the Supreme Court had recognized a claim for relief if an employer had bad numbers and could not explain them by reference to job-related qualifications, see id. at 209-14 (Blackmun, J., concurring). 
ble than the Warren Court's willingness to expand federal statutes to unanticipated situations.

From that same perspective, the Rehnquist Court's most aggressive interpretations are also more defensible. That Court frequently narrows federal statutes to protect state sovereignty and regulatory primacy. ${ }^{545}$ $B F P$ has been the most aggressive example of this approach, but its result and methodology can be defended from the perspective of the founding and consolidating periods. The statutory language of the bankruptcy law was open-ended, inviting contextual analysis. The governing context, Justice Scalia's opinion for the Court reasoned, was that applying the statute to reexamine foreclosure sales for reasonableness would not only supplant state law but would unsettle the security of property transactions and titles more generally. ${ }^{546}$ ln light of those consequences, the Court thought it better to err on the side of caution: Construe the law narrowly, and Congress could override the Court if it seriously objected. As in Weber, the Court construed the law amelioratively-in the latter case to protect state regulatory baselines, while in the former case to protect individual economic liberties. The archaeology in this Article suggests that, for the Framers and ratifiers, those interests would have been comparable.

3. The Rule of Continuity-And Aggressive Applications of the Voidance Power. - Finally, my historical account lends support to and deepens David Shapiro's suggestion that "close questions of construction should be resolved in favor of continuity and against change." 547 A major lesson I draw from the ratification debates and early cases like Bollman is that the rule of law is not just a law of rules, but a law of ongoing practice. The idea of Bonham's Case-that there is fundamental law stretching over decades or even generations that citizens ought to be able to take for granted-was an essential premise of Article 1II's judicial power and required cautious interpretations of statutes seeming to alter fundamental rights, especially constitutional rights. Recall Marshall's articulation of this point of view in Fisher. "Where rights are infringed, where fundamental principles are overthrown, where the general system of the laws is departed from, the legislative intention must be expressed with irresistable clearness to induce a court of justice to suppose a design to effect such objects." 548

The rule of continuity provides support for the Court's nontextualist approach to $B F P$, where the Court was narrowing a federal statute that seemed to create discontinuities for both state regulatory schemes and

545. E.g., Gregory v. Ashcroft, 501 U.S. 452, 470 (1991) (“In the face of such [statutoryl ambiguity, we will not attribute to Congress an intent to intrude on state governmental functions ....").

546. BFP v. Resolution Trust Corp., 511 U.S. 531, 544 (1994).

547. David L. Shapiro, Continuity and Change in Statutory Interpretation, 67 N.Y.U. L. Rev. 921, 925 (1992).

548. United States v. Fisher, 6 U.S. (2 Cranch) 358, 390 (1805). 
private property. $B F P$ can also be read for a more aggressive proposition, that federal statutes raising troubling constitutional issues should be narrowly (amelioratively) construed. ${ }^{549}$ This is one of the most controversial canons of statutory construction. Although modern commentators support the legitimacy of the canon that courts should interpret statutes to avoid a construction that violates the Constitution, some commentators strenuously object to what they see as a more recent variation, that courts should construe statutes to avoid troubling constitutional problems. ${ }^{550}$

The critics may well be correct, but early federal practice provides precedential support for both versions of the rule. Rutgers, M'Claws, and Vanhorme's Lessee applied the idea of Bonham's Case to narrow statutes whose literal interpretation would have violated the Constitution. But Bollman, arguably the greatest statutory decision of the Marshall Court, would support the broader version of the canon. Chief Justice Marshall did not suggest that Congress had no power to limit habeas grants to Supreme Court Justices in chambers rather than sitting as a Court, but he still started with the constitutional principle that Congress was obliged to give the writ teeth. That, together with the other contextual factors, supported a nonliteral interpretation of the habeas provision of the Judiciary Act.

I remain uncertain as to my own attitude toward the canon to avoid constitutional difficulties and toward $B F P$, but 1 view these notions as examples of the current productivity of historical inquiry. Others will occur to the gentle reader.

\section{ConCLusion}

John Manning's fascinating article is all about separation of powers. It is a brilliantly executed work of theory, for the author comprehensively reinterprets statutory practice in the founding and consolidating periods through the lens of strict separation of law-making and law-interpreting powers that he and other scholars believe was instinct in the new science of politics created in those years. Most of my objections arise from the observation that Manning's theory does not fit the facts as understood by the leading historians and as presented in this Article and others published in this Review. ${ }^{551} 1$ am pretty confident that Manning is factually off-base but worry that he is in the process of hitting a normative home

549. There is no suggestion in BFP that Congress does not have Article I authority to enact bankruptcy laws that preempt state property law, but the Court did cite to Gregory, 501 U.S. at 460-62, where the Court invoked constitutional principles of federalism and the Tenth Amendment to require a super-strong clear statement before Congress would be understood to regulate the states directly. BFP, 511 U.S. at 540.

550. E.g., Richard A. Posner, The Federal Courts: Crisis and Reform 284-85 (1985); John Copeland Nagle, Delaware \& Hudson Revisited, 72 Notre Dame L. Rev. 1495, 1495-98 (1997).

551. See Flaherty, History Lite, supra note 13, at 536-49; Martin S. Flaherty, History Right, supra note 25, at 2099-2105. 
run. That is, an ostensibly originalist but dedicatedly textualist or conservative Supreme Court is quite capable of accepting his normative theory-and then retro-fitting the historical materials to fit the theory, and not nearly so capably as Manning has done.

My Article is all about words: statutory words and how they assemble to form meanings; how they fit into a statutory scheme; how unruly they are, thus pressuring judges to maintain order among them; and how they can be vessels for principles or for policy inchoate until liquidated by application to a particular case. This includes normative words like equity of the statute. My Article has also explored particular words, "equity of the statute." This term of art once upon a time had a clear and uncontroversial signification for lawyers and judges, ${ }^{552}$ one that became fuzzier and more controversial by the late eighteenth century. By that point, it had become both legal boilerplate and a minor political bête-noir. The terminology was forgotten in the nineteenth century, only to be revived as a justification for expansive and purposive interpretation in the modern regulatory state. In Professor Manning's article, "equity of the statute" became a symbol for nonliteral constructions. Although my Article aspires to set the historical record straight as to the historical meanings of the term, I have probably introduced new anachronisms. The many faces of words should stand as a caution that Logos (textualism, old or new) is a Janus-faced god.

552. See supra note 22 and accompanying text. 